UNIVERSIDADE FEDERAL DO RIO GRANDE DO SUL

ESCOLA DE ENGENHARIA

PROGRAMA DE PÓS-GRADUAÇÃO MESTRADO PROFISSIONAL EM ENGENHARIA DE PRODUÇÃO

\title{
ProposiÇÃo de SiSTeMÁtica de AVAliAÇÃo de DESEMPENHO PARA PROCESSOS LICITATÓRIOS: O CASO DE UMA INSTITUIÇÃO FEDERAL DE ENSINO SUPERIOR
}


Evandro Luis Bobsin

Proposição de sistemática de avaliação de desempenho para processos licitatórios: o caso de uma Instituição Federal de Ensino Superior

Dissertação submetida ao Programa de PósGraduação Mestrado Profissional em Engenharia de Produção da Universidade Federal do Rio Grande do Sul como requisito parcial à obtenção do título de Mestre em Engenharia de Produção, modalidade Profissional, na área de concentração em Sistemas de Produção.

Orientador: Cláudio José Müller, Dr.

Porto Alegre 
Evandro Luis Bobsin

Proposição de sistemática de avaliação de desempenho para processos licitatórios: o caso de uma Instituição Federal de Ensino Superior

Esta dissertação foi julgada adequada para a obtenção do título de Mestre em Engenharia de Produção na modalidade Profissional e aprovada em sua forma final pelo Orientador e pela Banca Examinadora designada pelo Programa de Pós-Graduação Mestrado Profissional em Engenharia de Produção da Universidade Federal do Rio Grande do Sul.

Prof. Cláudio José Müller, Dr. Orientador PMPEP/UFRGS

Prof. Ricardo Augusto Cassel Coordenador PMPEP/UFRGS

\section{Banca Examinadora:}

Professor Daniel Garcia Haro, Dr.

Professor Néstor Fabián Ayala, Dr. (PMPEP/UFRGS)

Professora Priscila Wachs, Dr. (IFRS - CAMPUS CANOAS) 


\section{AGRADECIMENTOS}

Agradeço a todos aqueles que, de alguma forma, me ajudaram a chegar até aqui. Primeiramente, agradeço a Deus pela vida e pela vontade de realizar este sonho. À minha esposa, pelo amor, paciência, compreensão nas ausências momentâneas e pelo apoio nos momentos de dificuldade.

Ao meu orientador, Professor Cláudio Müller, que conduziu todo este processo de orientação com suas proposições e intervenções e que soube me guiar nos momentos em que eu mesmo não sabia para onde estava indo. Muito obrigado por estar sempre disponível.

Aos colegas do curso de mestrado, que compartilharam comigo as angústias durante os semestres e a difícil tarefa de conciliar os estudos, o trabalho profissional na UFRGS e a vida particular. O bom humor e a união tornaram essa caminhada mais divertida.

Finalmente, agradeço aos colegas de trabalho do DELIT que sempre me apoiaram nessa decisão e se colocaram à disposição para qualquer ajuda que eu precisasse. 


\section{RESUMO}

Os elementos essenciais para a produção de um determinado produto ou serviço, denominados insumos, são adquiridos de forma diversa, dependendo da natureza jurídica da relação de compra. As pessoas jurídicas de Direito Público precisam seguir uma série de leis infraconstitucionais e princípios insculpidos na Carta Magna. O tema aquisições de bens e serviços tornou-se um assunto relevante no âmbito da Administração Pública por ser um processo altamente regulado e burocrático. A maior cobrança de parte da sociedade por serviços de qualidade exige que a Administração Pública busque medidas para tornar os seus processos mais eficientes e mais eficazes. A Universidade Federal do Rio Grande do Sul - UFRGS está inserida neste cenário de necessidade de aprimorar o seu desempenho no exercício das suas competências relacionadas às aquisições de bens e serviços. Este trabalho se propõe a apresentar uma sistemática para avaliar o desempenho do processo licitatório de aquisição de bens e serviços em uma Instituição Federal de Ensino Superior, de forma a permitir a mensuração e a demonstração dos resultados do processo frente aos objetivos do órgão, através da aplicação dos conceitos de Business Process Management (BPM) e de Avaliação de Desempenho. Com a aplicação do método Design Science Research (DSR), inicialmente, identificaram-se os problemas relativos ao processo estudado e buscou-se temas na literatura disponível de forma a permitir a proposição de uma solução para os problemas levantados. Desenvolveu-se, com o apoio de um grupo focal, uma sistemática para avaliar o desempenho do processo, que na sequência foi aplicada em um ambiente real para a execução de testes. Na sequência, buscouse identificar, como resultado da aplicação, os principais obstáculos enfrentados durante a sua implantação e sugerir indicadores como forma de avaliar o desempenho do processo. O método desenvolvido foi aplicado na UFRGS, onde mostrou resultados satisfatórios, oportunizando a criação de um quadro com indicadores para medir os resultados desempenhados pelas principais atividades que compõem o processo estudado.

Palavras-chave: Indicador. Avaliação de Desempenho. Processo de licitação. Gestão de Processos. Setor Público. Gestão Pública. Instituição Federal de Ensino Superior. 


\begin{abstract}
The essential elements to produce a particular product or service, called inputs, are acquired in different ways, depending on the legal nature of the purchase relationship. Legal entities under public law must follow a series of infra-constitutional laws and principles enshrined in the Constitution. The topic of acquisitions of goods and services has become a relevant issue within the scope of Public Administration, as it is a highly regulated and bureaucratic process. The greater demand from society for quality services requires the Public Administration to seek measures to make its processes more efficient and effective. The Federal University of Rio Grande do Sul - UFRGS is inserted in this scenario of needing to improve its performance in the exercise of its competences related to the acquisition of goods and services. This work proposes to present a system to evaluate the performance of the bidding process for the acquisition of goods and services in a Federal Institution of Higher Education, in order to allow the measurement and demonstration of the results of the process against the objectives of the body, through the application of the concepts of Business Process Management (BPM) and Performance Evaluation. With the application of the Design Science Research (DSR) method, initially, the problems related to the studied process were identified and themes were searched in the available literature in order to allow the proposition of a solution to the raised problems. A system was developed, with the support of a focus group, to assess the performance of the process, which was then applied in a real environment for the execution of tests. Next, we sought to identify, as a result of the application, the main obstacles faced during its implementation and suggest indicators as a way to assess the performance of the process. The developed method was applied at UFRGS, where it showed satisfactory results, providing opportunities for the creation of a framework with indicators to measure the results performed by the main activities that make up the studied process.
\end{abstract}

Keywords: Indicator. Performance evaluation. Bidding process. Processes management. Public sector. Public Management. Federal Institution of Higher Education. 


\section{LISTA DE FIGURAS}

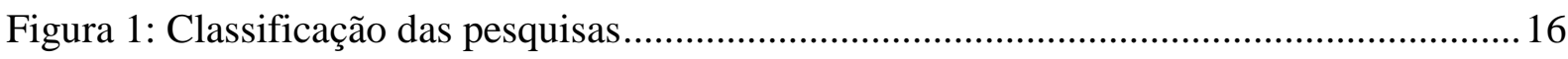

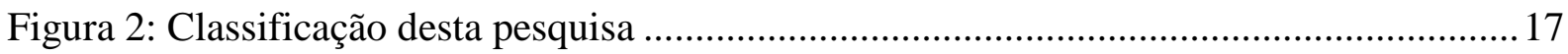

Figura 3: Princípios Constitucionais aplicáveis às Licitações .................................................2 27

Figura 4: As dimensões de qualidade, tempo, custo e flexibilidade....................................... 33

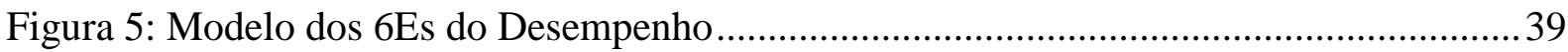

Figura 6: Etapas de medição e os 10 passos para a construção de indicadores......................... 41

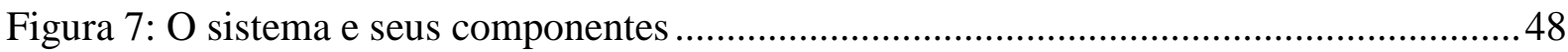

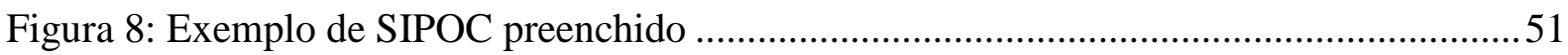

Figura 9: Resumo das ações planejadas para a execução do método do trabalho....................66

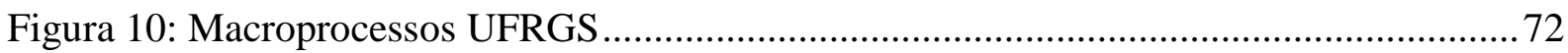

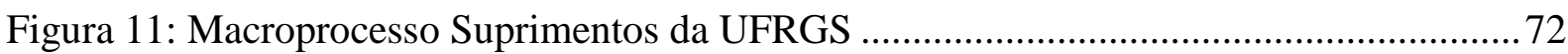

Figura 12: Caracterização SIPOC do Macroprocessos Suprimentos da UFRGS..................... 73

Figura 13: Esquema representativo das principais atividades dos processos P1 e P2 do

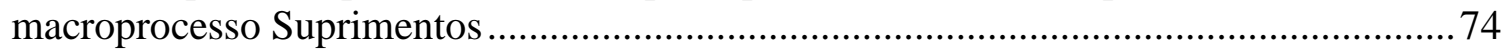

Figura 14: Sugestões planejadas para a execução do estudo ................................................ 83

Figura 15: Sugestão das ações planejadas para a execução no processo de estudo ................. 83

Figura 16: Etapas adotadas para o desenvolvimento da sistemática ....................................... 84

Figura 17: Etapas adotadas para a aplicação da sistemática...................................................93

Figura 18: Etapas adotadas para a avaliação da sistemática e dos resultados obtidos .............97 


\section{LISTA DE QUADROS}

Quadro 1: Compras governamentais no Brasil e nos Estados Unidos ....................................25

Quadro 2: Resumo dos modelos de avaliação de desempenho .............................................. 31

Quadro 3: Indicadores para dimensões de análise de desempenho ......................................... 38

Quadro 4: Definição dos componentes e critérios básicos para formulação de indicadores.... 43

Quadro 5: Resumo das principais aplicações dos temas nos processos de Compras Públicas 61

Quadro 6: Técnicas de coleta e análise de dados utilizadas no estudo. .67

Quadro 7: Legislação/regulamentação existente e o Formulário SEI para o macroprocesso de

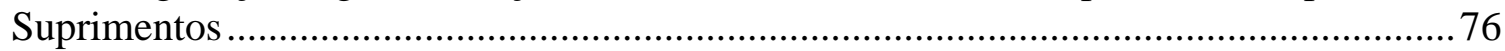

Quadro 8: Resumo das etapas de desenvolvimento da sistemática ........................................85

Quadro 9: Descrição dos elementos que os indicadores deverão apresentar .......................... 87

Quadro 10: Indicadores de Avaliação e Monitoramento do Desempenho do Processo de

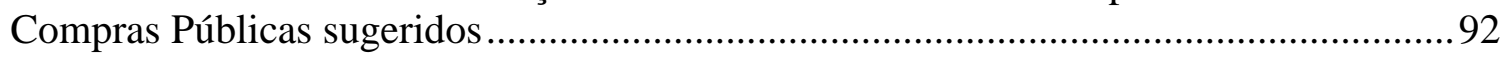

Quadro 11: Divisão do trabalho adotada para a aplicação da sistemática...............................95

Quadro 12: Resultado obtido durante a etapa de coleta de dados ..........................................96

Quadro 13: Indicadores de Avaliação e Monitoramento do Desempenho do Processo de Compras Públicas definitivos 103

\section{LISTA DE TABELAS}

Tabela 1: Número de licitações executadas a cada ano .78 


\section{LISTA DE SIGLAS}

AGU - Advocacia-Geral da União

BPM - Business Process Management

CPD - Centro de Processamento de Dados

DELIT - Departamento de Aquisição de Bens e Serviços

DIVIMPORT - Divisão de Importação

DIVLIC - Divisão de Execução da Licitação

DPCA - Divisão de Planejamento e Controle de Aquisições

DPL - Divisão de Preparo da Licitação

DSR - Design Science Research

EP - Escritório de Processos

ETP - Estudo Técnico Preliminar

IFE - Instituição Federal de Ensino

IFES - Instituição Federal de Ensino Superior

ME - Ministério da Economia

MEC - Ministério da Educação

PG - Procuradoria-Geral

PROPLAN - Pró-Reitoria de Planejamento e Controladoria

TCU - Tribunal de Contas da União

UFRGS - Universidade Federal do Rio Grande do Sul 


\section{SUMÁRIO}

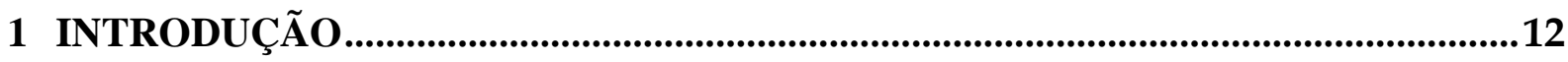

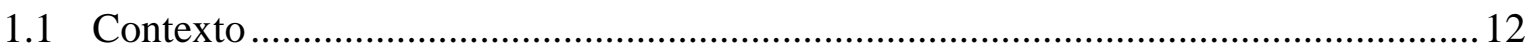

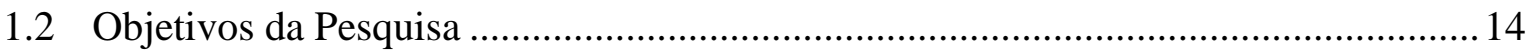

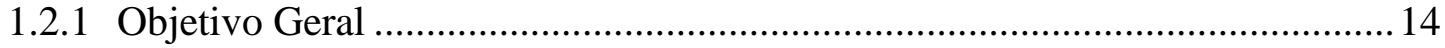

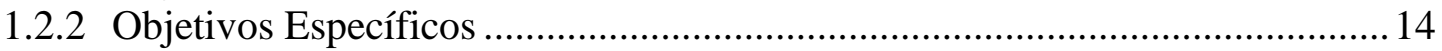

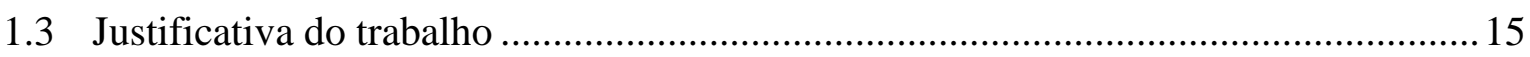

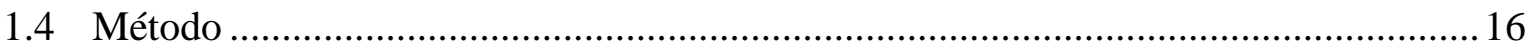

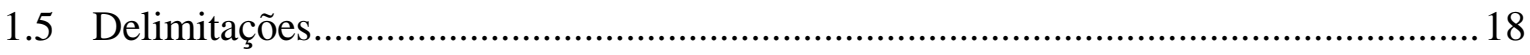

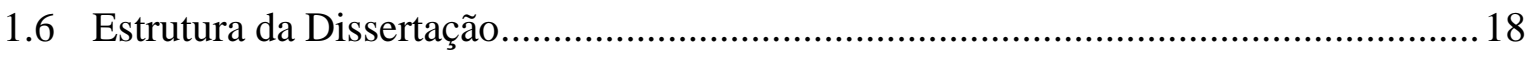

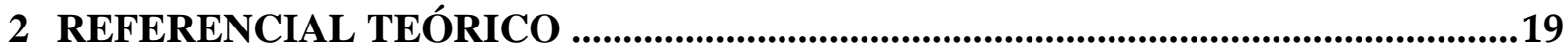

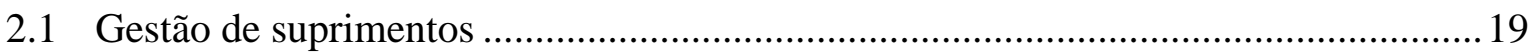

2.1.1 Gestão de suprimentos e processos licitatórios no Brasil................................ 19

2.1.2 Modelos de Compras Públicas no Brasil, EUA e UE ....................................21

2.1.3 Busca pela eficiência nas Compras Públicas .................................................. 26

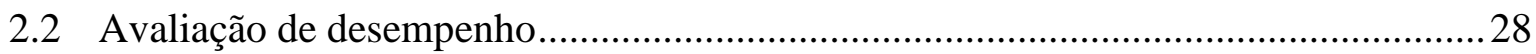

2.2.1 Modelos de avaliação de desempenho ……...................................................29

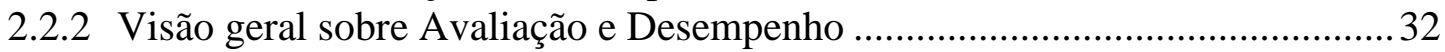

2.2.3 Avaliação de Desempenho na Administração Pública ...................................... 35

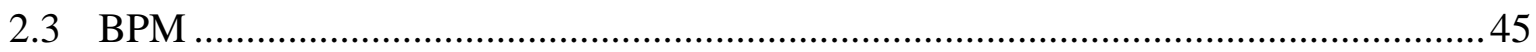

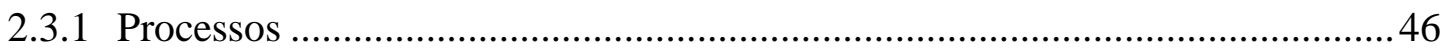

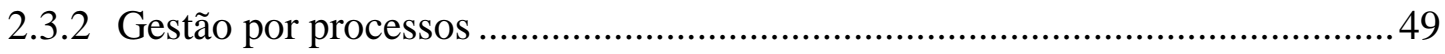

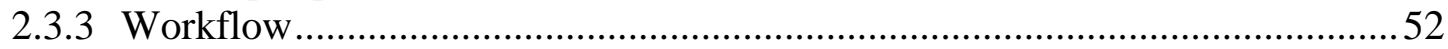

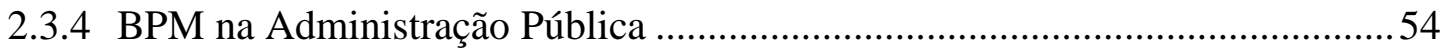

2.4 Aplicação dos Temas nos processos de Compras Públicas ..........................................57

2.4.1 Avaliação de Desempenho aplicada em processos de Compras Públicas ........57

2.4.2 BPM aplicado aos processos de Compras Públicas ......................................59

2.4.3 Considerações sobre a revisão da literatura................................................. 62

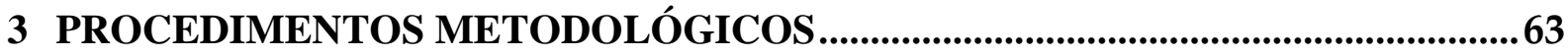

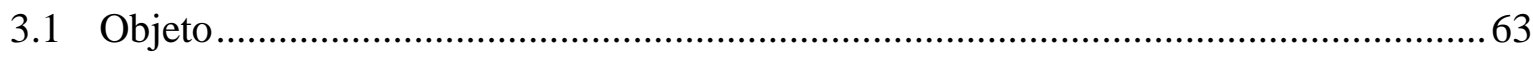

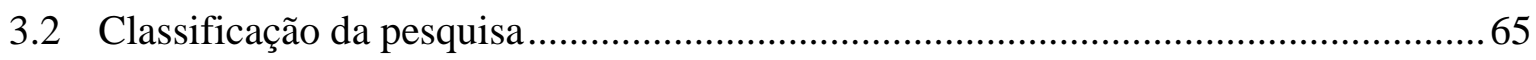

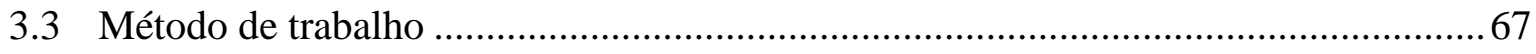

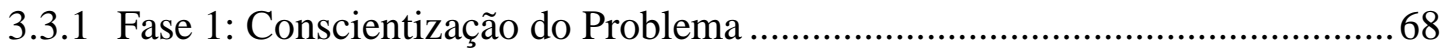

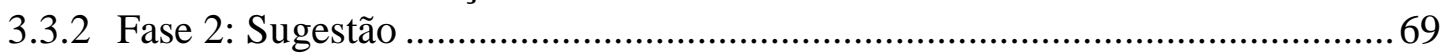

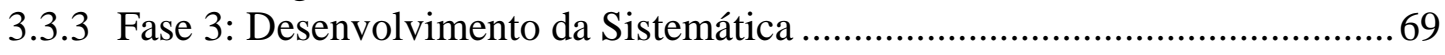

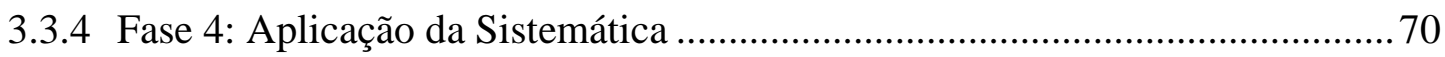

3.3.5 Fase 5: Avaliação da Sistemática ................................................................ 70

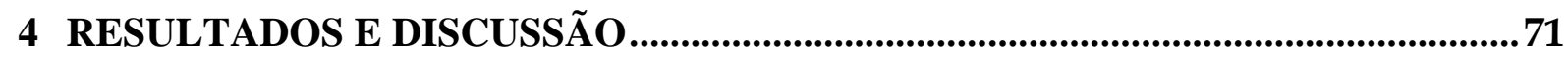

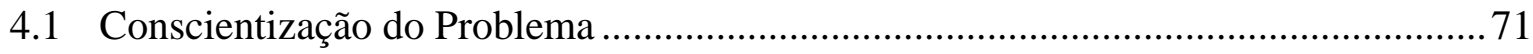

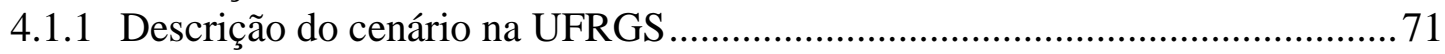

4.1.2 Identificação e contexto do problema do processo estudado ...........................8 80

4.1.3 Contexto da Avaliação de desempenho ...................................................... 81 


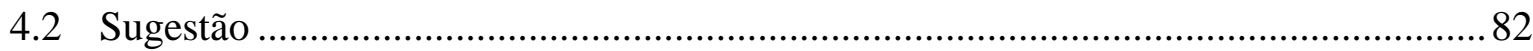

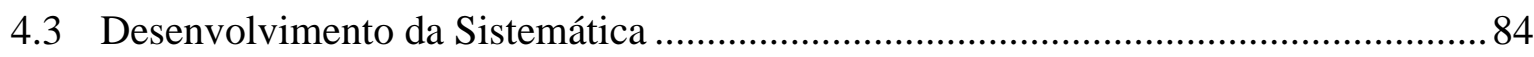

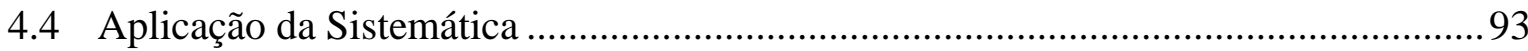

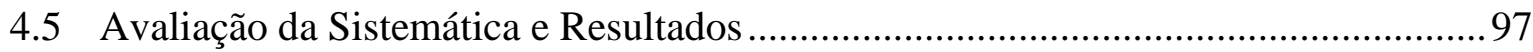

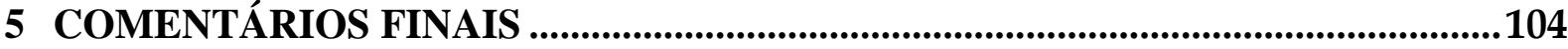

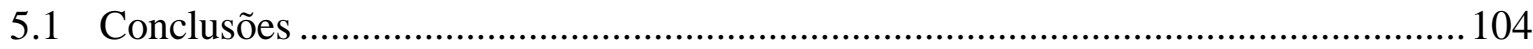

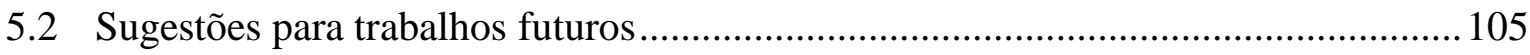

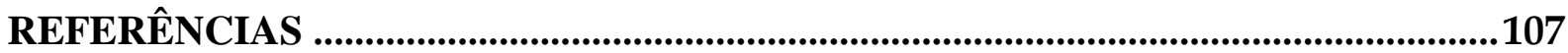

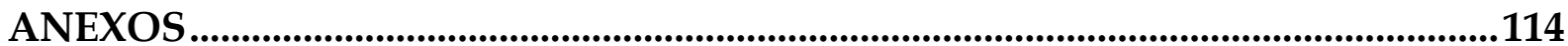




\section{Introdução}

\subsection{Contexto}

A sociedade é formada por pessoas que demandam bens ou serviços para suprir suas necessidades, sejam elas fisiológicas, de segurança, sociais, de status ou de autorrealização. As organizações surgiram, no decorrer do tempo, para suprir estas necessidades por meio da prestação de serviços ou do fornecimento de bens (BATISTA; MALDONADO, 2008).

Os insumos usados na produção de um determinado produto ou serviço são adquiridos de forma diversa, dependendo da natureza jurídica da relação de compra. Enquanto as pessoas físicas têm a liberdade de negociar livremente cobre como que esta relação se efetivará (utilizando muitas vezes critérios subjetivos, pessoais e até mesmo emocionais), segundo Borges et al. (2016) a aquisição de um bem ou a contratação de um serviço pelas pessoas jurídicas de Direito Público devem seguir uma série de leis que procuram, através do regramento, tornar a relação o mais objetiva possível.

As novas necessidades da sociedade, que demanda serviços públicos melhores e mais eficazes, estão promovendo uma mudança na forma da gestão organizacional pública. Ao mesmo tempo em que as ações públicas devem estar em conformidade com os princípios básicos da administração pública, em especial legalidade, eficiência e publicidade (BRASIL, 1988; BORGES, 2016), os órgãos públicos precisam ser competitivos para conseguirem se sustentar e sobreviver a longo prazo. A manutenção da competitividade depende do alinhamento da organização com a estratégia escolhida, devendo a mesma ser vista como o atendimento dos requisitos/necessidades dos clientes e dos objetivos estratégicos do órgão. As atividades realizadas pelos departamentos e pelos funcionários devem estar alinhadas às estratégias organizacionais e, além da escolha da rota, a organização precisa medir se está na rota escolhida. Medições e controles devem induzir os processos de forma a serem os elos entre os objetivos e a execução prática das atividades da organização (MULLER, 2014).

Para Hronec (1994), as medidas de desempenho são os sinais vitais da organização, que comunicam: a estratégia para baixo, os resultados dos processos para cima e o controle e a melhoria dentro dos processos, quantificando o quão bem as atividades inerentes ao processo ou o seu output atingem uma meta específica. Müller (2014) coloca que a avaliação de 
desempenho permite avaliar se o plano traçado está sendo cumprido, sendo vital a medição dos processos e dos resultados e a comparação dos mesmos com os objetivos predeterminados.

A Constituição Federal, no seu art. 37, inciso XXI, define que, ressalvados os casos especificados na legislação, as obras, serviços, compras e alienações serão contratados mediante processo de licitação pública que assegure igualdade de condições a todos os concorrentes, com cláusulas que estabeleçam obrigações de pagamento, mantidas as condições efetivas da proposta, nos termos da lei, o qual somente permitirá as exigências de qualificação técnica e econômica indispensáveis à garantia do cumprimento das obrigações (BRASIL, 1993).

A lei que regulamenta este dispositivo constitucional e estabelece as normas gerais sobre licitações e contratos da Administração Pública é a Lei 8.666/93 (BRASIL, 1993). Ela define as modalidades de licitação (convite, tomada de preços, concorrência, concurso e leilão), bem como as situações de dispensa e inexigibilidade licitatória. Adicionalmente, existe a Lei 10.520/2002, que institui uma nova modalidade de licitação denominada pregão (BRASIL, 2002).

O tema aquisições de bens e serviços tornou-se um assunto relevante no âmbito da Administração Pública por ser um processo altamente regulado e burocrático. A maior cobrança de parte da sociedade por serviços de qualidade exige que a Administração Pública busque medidas para tornar os seus processos mais eficazes com um gasto mínimo de recursos (CAVEDO, 2020; MARQUES, 2005; PUGLIESE, 2019).

A Universidade Federal do Rio Grande do Sul - UFRGS, pessoa jurídica de Direito Público, está inserida neste cenário e o seu procedimento licitatório servirá de base para o desenvolvimento deste estudo. A UFRGS foi escolhida para este estudo porque o pesquisador é servidor integrante do seu quadro efetivo de servidores e trabalha no setor responsável pelas compras do órgão.

A questão que se propõe é estabelecer medidas para que os gestores possam reconhecer quando o processo licitatório está ou não cumprindo suas funções de forma satisfatória, estabelecendo indicadores para avaliar o desempenho do processo. Sem as medidas do desempenho, faltarão fundamentos suficientes para os gestores poderem: (i) comunicar aos colaboradores as expectativas de desempenho; (ii) saber o que está acontecendo na organização e na sua área de atuação; (iii) identificar deficiências de desempenho que poderiam ser 
eliminadas ou revistas; (iv) fornecer feedback aos colaboradores, demonstrando seu real desempenho em relação ao que foi planejado; (v) adotar decisões fundamentadas e que possam ser justificadas de forma transparente (RUMMLER; BRACHE, 1994). As medidas de desempenho possibilitam ao ambiente organizacional, segundo Harrington (1993): (i) identificar o estágio atual da empresa quanto aos objetivos que se pretende alcançar; (ii) avaliar a necessidade de alterações, frente a divergência entre o planejado e o que foi ou está sendo executado; (iii) priorizar mudanças capazes de influenciar positivamente os rumos da instituição; (iv) rever cronogramas e rumos de ação.

A partir do contexto e do problema de pesquisa apresentados, a implementação de algum sistema de indicadores que possibilite avaliar o desempenho dos processos licitatórios para a aquisição de bens e contratação de serviços das organizações de natureza pública se mostra aconselhável, ao trazer para estas organizações a realidade das práticas adotadas de gestão de processos usadas em âmbito mundial, objetivando que as ocorrências de avaliações e de análises internas conduzam à melhoria contínua.

\subsection{ObJetivos da Pesquisa}

Os objetivos do trabalho podem ser apresentados em nível geral e específico.

\subsubsection{Objetivo Geral}

O objetivo do trabalho é desenvolver uma sistemática de avaliação de desempenho para processos de compras que utilizam o procedimento licitatório.

\subsubsection{Objetivos Específicos}

Com este trabalho, pretende-se, adicionalmente:

a) aplicar a sistemática proposta no processo escolhido em uma IFE;

b) identificar, junto à organização objeto do estudo, os principais obstáculos enfrentados durante a implantação de uma sistemática de avaliação de desempenho, bem como demais problemas enfrentados pela organização no processo estudado envolvendo estratégia, indicadores e operações; 
c) sugerir a adoção de indicadores que possibilitem avaliar o desempenho de um processo, de modo que o mesmo se torne aderente às organizações de natureza pública.

\subsection{JUSTIFICATIVA DO TRABALHO}

A discussão isolada de Avaliação de Desempenho (AD) e Gestão por Processos (GP) pode se tornar um erro em termos de gestão empresarial. Para Müller (2014), um dos problemas da gestão empresarial está justamente na falta de integração de sistemáticas que, isoladas, não levam a resultados satisfatórios. As organizações devem ter um conjunto de sistemáticas que mantenham a relação entre os níveis estratégico, tático e operacional.

Em termos de avaliação de desempenho, Müller (2014) afirma que as organizações precisam medir o resultado das suas operações para verificar se o plano elaborado está sendo cumprido, utilizando-se, para isto, dos indicadores, bem como verificar se os resultados locais estão contribuindo para o alcance das metas do Planejamento Estratégico. A Gestão de Processos está presente em todas as organizações, tanto no âmbito público quanto no privado, sendo utilizada para otimizar resultados ao melhorar os processos de negócio e, consequentemente, a produtividade da empresa.

O estudo visa contribuir com a ampliação do conhecimento sobre os processos licitatórios e seus principais problemas no âmbito da UFRGS, proporcionando uma melhoria da condução do processo pelo Departamento de Licitações da UFRGS. O desenvolvimento de uma sistemática de avaliação de desempenho é importante pois possibilitará levantar informações que poderão ser utilizadas para melhorar o desempenho do processo com a consequente melhoria na percepção da qualidade do serviço prestado na ótica do cliente interno, bem como devido a possibilidade de utilização e de adaptação de seu uso por outras instituições públicas. Justifica-se a escolha desse órgão pelo fato do autor ser servidor do mesmo, bem como por estar lotado no departamento responsável pelo planejamento e realização das compras e por estas atividades estarem listadas nos planos dos Objetivos organizacionais do Plano de Gestão: "Definir política e desenvolver planejamento e controle das aquisições de forma integrada e alinhada aos objetivos institucionais".

Os resultados obtidos neste estudo visam ofertar às IFEs, e a outros órgãos públicos que também se utilizam de processo de licitação, meios de promover a mensuração das atividades da área de licitações, de forma que seja possível medir e avaliar o desempenho nas 
atividades que compõem o procedimento licitatório estabelecido. Busca-se, assim, proporcionar ferramentas de melhoria do processo para torná-lo mais eficiente, fazendo com que ocorra melhoria no planejamento, no controle, na tomada de decisão e na qualidade dos serviços executados.

\subsection{MÉTODO}

De acordo com Severino (2013), existem várias formas de classificar pesquisas. As formas tradicionais de classificação são do ponto de vista da sua natureza (básica ou aplicada), da forma de abordagem do problema (quantitativa ou qualitativa), de seus objetivos (exploratória, descritiva ou explicativa) e dos procedimentos técnicos (bibliográfica, documental, experimental, levantamento, estudo de caso, ex-post-facto, pesquisa-ação e participante). Na Figura 1, apresenta-se, de forma esquemática, esta metodologia de classificação das pesquisas.

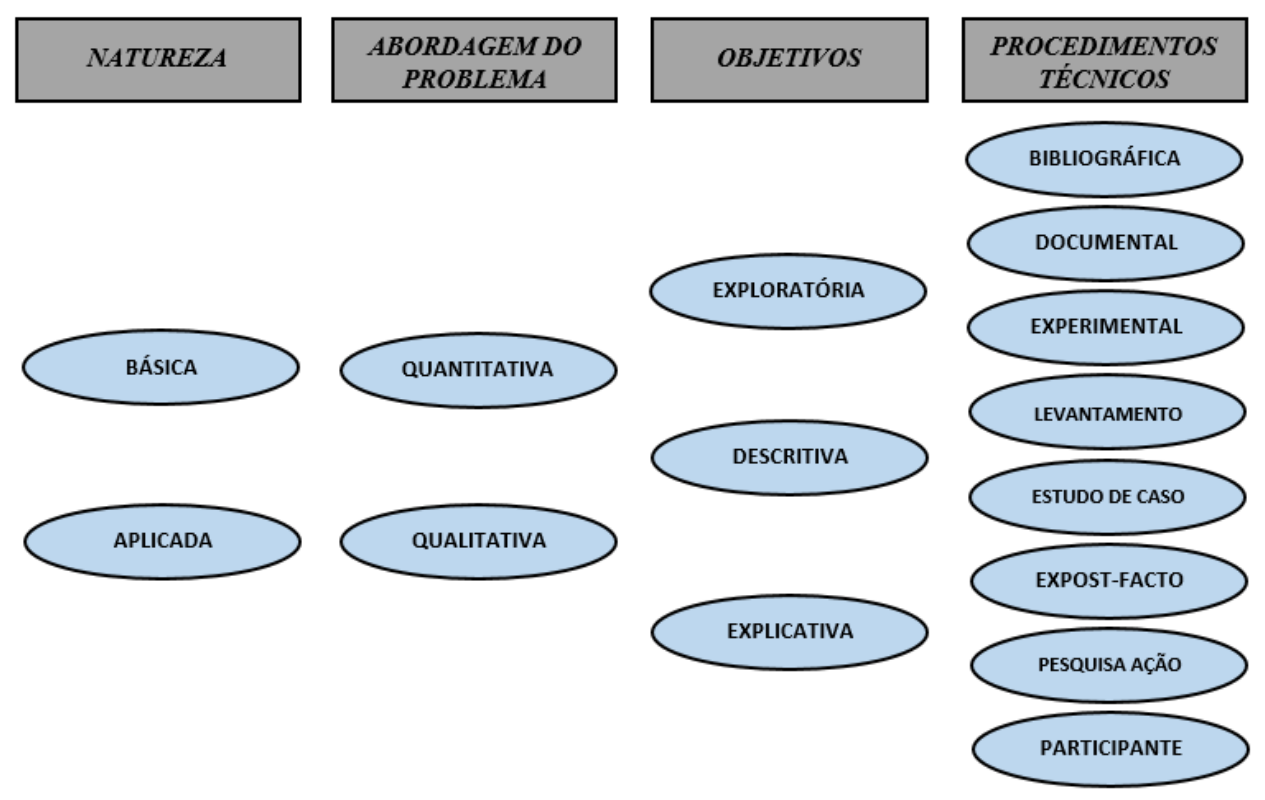

Figura 1: Classificação das pesquisas

Fonte: Meneses (2006, p. 17)

Quanto à natureza, este trabalho é classificado como pesquisa aplicada, uma vez que objetiva gerar conhecimentos para aplicação prática, dirigidos à solução de problemas específicos, envolvendo verdades e interesses locais. Já do ponto de vista da forma de abordagem do problema, a presente pesquisa possui basicamente caráter qualitativo, pois interpreta fenômenos e atribui significado (SILVA; MENEZES, 2000). 
A pesquisa em pauta, em se tratando de seus objetivos, pode ser classificada como explicativa, visto que envolve levantamento bibliográfico sobre um determinado objeto, registro e análise dos fenômenos estudados e a busca e a identificação das suas causas de forma a permitir a aplicação de um método experimental para a análise de exemplos que estimulam a compreensão. Isso se enquadra na definição de pesquisa explicativa de Severino (2013).

Quanto aos procedimentos técnicos, essa pesquisa se classifica como (i) bibliográfica, por ter sido elaborada, também, a partir de material já publicado, constituído de livros, artigos de periódicos e materiais disponibilizados na internet, (ii) levantamento, por envolver a interrogação direta a pessoas durante o estudo de caso proposto para avaliar a implantação e a manutenção do modelo desenvolvido e (iii) pesquisa-ação (SILVA; MENEZES, 2000), por se tratar de uma estratégia de pesquisa que agrega vários métodos ou técnicas de pesquisa, com os quais se estabelece uma estrutura coletiva, participativa e ativa no nível da captação da informação. O emprego da pesquisa-ação justifica-se neste trabalho por se tratar de uma estratégia de pesquisa com finalidade prática, a qual inclui, entre seus pressupostos, a participação ativa dos atores da situação observada.

Dessa forma, a pesquisa pode ser classificada, de modo geral, segundo a Figura 2.

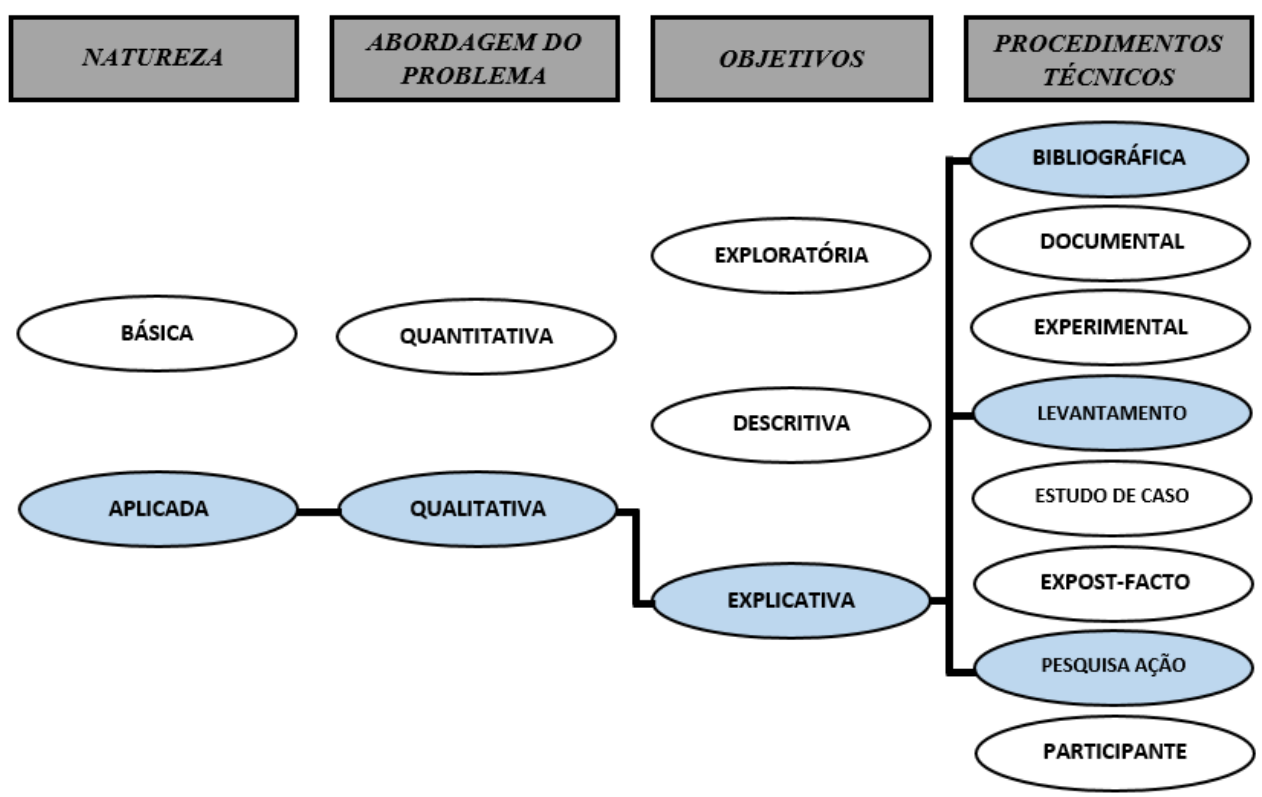

Figura 2: Classificação desta pesquisa

Fonte: Elaborado pelo autor a partir da Figura 1 


\subsection{DeLimitações}

A presente dissertação não pretende entrar na discussão da avaliação por parte dos cidadãos dos serviços que são disponibilizados para uso geral pelo setor público, estando focada na medição do desempenho do processo licitatório. A pesquisa desenvolverá uma sistemática de avaliação de desempenho para processos de compras por licitação limitado, neste trabalho, aos processos Planejamento de Aquisições e Aquisição de Bens e Serviços integrantes do macroprocesso Suprimentos.

O trabalho também não abrange a avaliação do desempenho de pessoas, mas está voltado para um processo interno da organização considerado importante para a mesma, identificando as conexões e possibilidades de uso de BPM na Administração Pública. A modelagem do processo também não faz parte do escopo do estudo, sendo utilizado o mapeamento disponível na organização.

Considerando que o método desenvolvido é testado a partir de uma única aplicação, o trabalho limita-se ao contexto desta aplicação: uma Instituição Federal de Ensino Superior, de forma que sua utilização em outras realidades requer um estudo prévio que considere suas peculiaridades e possíveis adaptações.

\subsection{Estrutura Da DisSERTAÇ̃̃o}

O trabalho está estruturado em 5 capítulos. No capítulo 1, tem-se a visão geral do trabalho. No capítulo 2, faz-se a revisão da literatura sobre Avaliação de Desempenho e Gerenciamento de Processos e a aplicação dos temas na Administração Pública, respectivamente. Também será realizada uma breve abordagem sobre compras nas organizações públicas. No capítulo 3, são demonstrados os métodos de trabalhos adotados na condução da pesquisa. No capítulo 4 , são realizadas discussões da aplicação da sistemática que embasam as sugestões de proposições de indicadores, visando monitorar o desempenho de um processo que é crítico do ponto de vista estratégico da organização objeto do estudo. No capítulo 5, são abordadas as conclusões da pesquisa e as recomendações para trabalhos futuros. 


\section{Referencial Teórico}

Neste capítulo evidencia-se a síntese da fundamentação teórica deste trabalho, onde se destacam os seguintes tópicos: gestão de suprimentos, avaliação de desempenho, metodologias de gestão de processos e, finalmente, processo de compras públicas governamentais.

\subsection{GESTÃo DE SUPRIMENTOS}

Este capítulo trará os aspectos relacionados à gestão de suprimentos aplicados ao ambiente das organizações públicas, assim como um breve descritivo sobre como se dá os processos licitatórios no Brasil, nos Estados Unidos e na União Europeia.

\subsubsection{Gestão de suprimentos e processos licitatórios no Brasil}

A gestão de suprimentos é uma atividade importante para qualquer instituição pública. Segundo Batista e Maldonado (2008), a área de compras desempenha um papel importante na realização dos objetivos estratégicos da instituição, por se tratar de um dos locais em que se aplicam os recursos orçamentários existentes na organização e em que se efetivam os processos de compras, através do que materiais, bens e serviços necessários ao alcance dos objetivos da instituição serão adquiridos.

A gestão de suprimentos compreende a compra, a aquisição e a guarda dos materiais, dos bens e dos serviços necessários à manutenção e ao desenvolvimento das atividades realizadas no âmbito da instituição, proporcionando suprimento constante de materiais necessários para utilização nas atividades gerais, cabendo ao gestor público a obrigatoriedade da observação da adoção de licitações pelos órgãos públicos (BATISTA; MALDONADO, 2008; PEREIRA, 2019).

Para o setor público, a gestão de suprimentos é muito mais do que o ato de comprar produtos e serviços pelo menor preço: trata-se da procura e da escolha da oferta de melhor qualidade e de preço justo, conforme as regras preestabelecidas antes da aquisição. Ao mesmo tempo que traz a todos os concorrentes interessados igualdade de participação, para a Administração o processo licitatório significa a contratação da proposta mais vantajosa, 
cabendo, também, cumprir fielmente com toda a legislação que regulamenta as diversas modalidades de licitação (ADRIANO, 2013).

Batista e Maldonado (2008) afirmam que os clientes de um setor de compras e licitações são todos aqueles que, direta ou indiretamente, necessitam adquirir produtos e/ou serviços para alcançar os resultados almejados. Torna-se extremamente importante que este setor leve em consideração tais clientes, sendo necessária a existência do entendimento do macroprocesso de compras da organização, de maneira a propiciar uma visão dos procedimentos licitatórios, com as suas relações interdepartamentais, levando em consideração o fluxo das informações e a sua velocidade de fluidez. A partir deste entendimento, toda melhoria identificada e implantada poderá acarretar uma diminuição das atividades nos processos internos e um aumento na rapidez das resoluções e na tomada de decisões, propiciando uma melhor relação entre as atividades-meio e as finalísticas da organização.

A Lei 8.666, de 21 de junho de 1993 (BRASIL, 1993), conceitua compra "como toda aquisição remunerada de bens para fornecimento de uma só vez ou parceladamente" e diz que a sua finalidade é a de suprir com os materiais ou serviços necessários, em quantidades e qualidades certas, a preço adequado, e no momento certo. Batista e Maldonado (2008) sugerem uma definição mais ampla para os objetivos de compras, a saber:

- $\quad$ suprir a organização com um fluxo seguro de materiais e serviços para atender às suas necessidades;

- assegurar continuidade de suprimento para manter relacionamentos efetivos com fontes existentes, desenvolvendo outras fontes de suprimentos alternativas, ou para atender às necessidades emergentes ou planejadas;

- comprar eficiente e sabiamente, obtendo, por meios éticos, o melhor valor por centavo gasto;

- administrar estoques para proporcionar o melhor serviço possível aos usuários ao menor custo;

- manter relacionamentos cooperativos sólidos com outros departamentos, fornecendo informações e aconselhamentos necessários para assegurar a operação eficaz de toda a organização;

- desenvolver funcionários, políticas, procedimentos e organização para assegurar o alcance dos objetivos previstos. 
Uma licitação deve assegurar a idoneidade, a isonomia e a competitividade para que a compra seja feita da forma mais vantajosa para a Administração (ADRIANO, 2013).

\subsubsection{Modelos de Compras Públicas no Brasil, EUA e UE}

As organizações públicas possuem características diversas das privadas. Estas características acabam por direcionar o comportamento da organização pública para uma forma de expressão mais formal, visto que todos os atos públicos devem estar respaldados por lei ou por normas subsidiárias. Desta forma, é possível ver uma diferença em relação aos atos praticados pela iniciativa privada e pelo setor público. Com relação às compras públicas no Brasil não é diferente: os órgãos públicos devem seguir os regramentos rígidos existentes para a utilização dos recursos públicos. As compras e demais contratações realizadas pelos entes públicos possuem distinção daqueles realizados pelos privados, tendo em vista que devem ser totalmente vinculadas à legislação relacionada, inclusive no que diz respeito aos seus procedimentos e normativas (ALVES, 2017).

Conforme Cavedo (2020), a Lei 8.666/1993 (Lei de Licitações e Contratos Administrativos) regulamenta o artigo 37, inciso XXI, da Constituição Federal, que estabeleceu as normas gerais sobre licitações e contratos administrativos pertinentes a compras, obras, serviços (inclusive de publicidade), alienações e locações no âmbito dos Poderes da União, dos estados, do Distrito Federal e dos municípios. A Lei de Licitações estabelece ritos comuns e formais sobre licitações e contratos administrativos, eliminando qualquer flexibilidade do gestor, tendo a sua aplicação obrigatória para as autarquias, os fundos especiais, as fundações, as empresas públicas, as sociedades de economia mista e demais entidades controladas direta ou indiretamente pela União, pelos estados, pelo Distrito Federal e pelos municípios.

O objetivo da licitação, para Cavedo (2020), é permitir que a Administração, de forma isonômica, escolha interessados em fornecer bens ou serviços para atender suas demandas, levando em consideração o valor do objeto, a qualidade do produto e a capacidade técnica e econômico-financeira da empresa licitante. Pereira (2019) também destaca dentre os objetivos da licitação o da garantia da observância do princípio constitucional da isonomia e o da seleção da proposta mais vantajosa para a Administração. Estes objetivos se propõem a assegurar a igualdade a todos os interessados, de forma a possibilitar o comparecimento ao certame do maior número possível de concorrentes, buscando obter maior economicidade nas compras da Administração Pública. 
A licitação é, portanto, um procedimento administrativo formal em que a Administração Pública convoca, por meio de condições estabelecidas em ato próprio (edital ou convite), empresas interessadas em apresentar propostas para o oferecimento de bens e serviços, devendo a Administração Pública valer-se, prioritariamente, de procedimento licitatório formal para suprir as suas demandas por bens e serviços, observando o disposto nas normas do Direito Público. Diferentemente, o ente privado realiza suas contratações de forma discricionária e seguindo os seus próprios critérios (TRILHA, 2018; PEREIRA, 2019; CAVEDO, 2020).

Segundo Pereira (2019), a Lei 8.666/1993 dita o rito pelo qual a Administração Pública deve se guiar e por meio do qual se realizará as contratações de serviços, as aquisições de produtos e a celebração dos contratos entre Administração Pública e o setor privado, precedidas por um procedimento administrativo licitatório, exceto para aqueles casos específicos em que a legislação dispensa a licitação.

Cavedo (2020) afirma que a licitação é dividida em duas fases: a interna e a externa. A fase interna constitui-se de uma etapa de preparação da licitação em que é definido, em síntese, o objeto a ser licitado, é realizada a pesquisa de preços e elaborado o edital. A fase externa consiste na etapa em que a Administração disponibiliza aos interessados as informações e condições do procedimento licitatório, por intermédio da publicidade do edital, estendendo-se até a contratação do fornecimento do bem, da execução da obra ou da prestação dos serviços. A fase externa é subdividida em duas etapas: a primeira, chamada etapa de habilitação, referese à análise quanto à comprovação de que o licitante possui as condições para a execução do objeto do certame; abrange o exame da qualificação técnica e econômico-financeira, da sua regularidade fiscal e trabalhista e da habilitação jurídica da empresa; a segunda etapa diz respeito ao exame das propostas, no que tange a montantes financeiros envolvidos e às condições de entrega do bem ou prestação do serviço.

O procedimento licitatório, segundo Pereira (2019), possui fases sequenciais determinadas pela legislação vigente. A primeira delas é a abertura do processo administrativo, que contempla o início do processo administrativo de licitação, ainda na fase interna, quando é definido o objeto pretendido e realizada a confirmação da existência de recursos financeiros para honrar a despesa; é nesta fase que é detalhado e especificado o que se busca contratar ou adquirir. A próxima fase é a de elaboração do instrumento convocatório (edital), na qual deverão constar as informações pertinentes para os interessados tomarem conhecimento a respeito das regras e dos critérios que serão adotados na escolha da proposta da empresa 
vencedora da licitação. Na sequência, se dará a fase de publicidade do instrumento convocatório, dando-se início à fase externa, onde os interessados terão ciência das informações contidas no edital e a Administração Pública externalizará o seu interesse pela aquisição demandada. O recebimento e julgamento das propostas é a fase em que as propostas, a documentação relativa à habilitação jurídica, qualificação técnica e qualificação econômicofinanceira e a documentação relativa à regularidade fiscal e trabalhista dos interessados são analisados. Escolhida a melhor proposta dentre os participantes, a fase seguinte é chamada de homologação, na qual ocorre a comprovação pela autoridade competente da licitude de todo o procedimento licitatório executado. A última fase, chamada de adjudicação, é o ato pelo qual a Administração atribui ao vencedor o objeto da licitação, declarando o vencedor da licitação e formalizando a relação entre as partes com a confecção de contratos administrativos.

Este é o modelo de compras públicas adotado no Brasil. Para a avaliação deste modelo com relação aos diferentes modelos de compras públicas existentes, foram escolhidos o modelo estadunidense, por se tratar de um país reconhecido como potência mundial em relação ao seu poderio econômico, e o modelo praticado na União Europeia, o bloco de mercados regionais formado pelos países na Europa de maior importância econômica.

Nos Estados Unidos, existe a consciência de que a iniciativa privada, em seu ambiente competitivo, tem a possibilidade de agir com maior eficiência e, por isso, o Estado americano se vale muito do setor privado para atender às necessidades públicas. A interação entre governo e vendedor nos EUA ocorre basicamente por meio de procedimentos concorrenciais informados por princípios como os da competitividade, da igualdade de tratamento e da economia de custos. Há diversos canais de comunicação entre o governo e o mercado, muitos disponíveis na internet (e-Procurement). Além disso, ante a complexidade da contratação pública, há nos Estados Unidos centros de apoio voltados para orientar o mercado em relação às contratações governamentais, que são os Procurement Technical Assistance Centers - PTACs. Esses centros são administrados pelo Departamento de Defesa americano e têm como intuito oferecer suporte ao mercado nos negócios governamentais (OLIVEIRA, Aline, 2018).

Devido à repartição de poder nos EUA se dar em nível nacional (federal), estadual e local, cada um destes entes é competente para elaborar sua própria legislação, existindo assim a lei federal, a estadual e a local sobre contratos públicos. A principal norma é a federal, que influencia as dos estados e que também deve ser obedecida pelos entes da federação no caso de os mesmos virem a contratar com recursos da União americana. Existem diversas normas sobre 
o tema em âmbito federal, sendo a Federal Acquisition Regulation - FAR a norma geral na qual constam regras sobre contratação de obras, serviços e bens. A legislação americana sobre procurement sofreu uma profunda reforma na primeira metade dos anos 90 que teve como principal foco a simplificação das pequenas compras e a busca por resultados. A legislação americana tem regras fixas em relação ao procedimento, mas possui considerável discricionariedade no que diz respeito ao critério de julgamento das propostas e à definição dos requisitos para a contratação (descrição do objeto e qualificação da empresa contratada) (OLIVEIRA, Aline, 2018).

O objetivo do FAR é satisfazer o governo em termos de custo, qualidade e pontualidade do produto ou serviço entregue, se propondo a: (i) maximizar o uso de produtos e serviços comerciais; (ii) utilizar contratados com histórico de desempenho passado bem-sucedido ou que demonstrem uma capacidade superior atual de desempenho; e (iii) promover a concorrência. Além disso, tem como propósitos: (1) minimizar custos operacionais administrativos; (2) conduzir negócios com integridade, justiça e abertura; e (3) cumprir os objetivos de política pública (CAVEDO, 2020).

Com relação à execução da política de incentivos nas aquisições públicas norte americana, dois programas se destacam: o Buy American Act, direcionado para dar preferência na aquisição de produtos nacionais, e o Small Business Act, voltado para a compra de produtos das micro e pequenas empresas. O Buy American Act é visto como um ato de proteção da produção nacional que objetiva o fortalecimento da indústria e a promoção de empregos, estabelecendo restrições à compra de bens não produzidos nos EUA, salvo nos casos de indisponibilidade interna do produto, preços não razoáveis e do interesse da Administração (CAVEDO, 2020).

O modelo de compra pública americano apresenta algumas diferenças em relação ao modelo brasileiro. O modelo americano adota como critério de seleção dos contratados a relação entre custos e benefícios públicos (foco no resultado), ao passo que, no Brasil, ainda é usado como principal critério de seleção o menor preço ofertado. Outra diferença está no sistema americano admitir maior discricionariedade para o gestor em relação aos critérios de julgamento da proposta e no tocante à definição do objeto e às credenciais do contratado; no modelo brasileiro não há esta possibilidade, já que os termos e critérios estão estabelecidos em lei. Ainda, os EUA escolheram privilegiar a produção nacional, principalmente as micro e pequenas empresas (MPE), esforçando-se para reduzir os entraves às firmas que pretendem 
fornecer ao governo e admitindo margens de preferência para os bens e serviços nacionais. $\mathrm{O}$ Brasil busca uma concorrência ampla e aberta, não importando a nacionalidade ou tamanho da empresa, e os procedimentos complexos são voltados para inibir a corrupção (MARQUES, 2005).

O Quadro 1 resume as principais características das políticas de compras públicas destes dois países.

\begin{tabular}{|c|c|c|}
\hline \multicolumn{3}{|c|}{ PRINCIPAIS MEDIDAS ADOTADAS NAS COMPRAS PÚBLICAS DE BRASIL E EUA } \\
\hline Medidas & EUA & BRASIL \\
\hline Lei única para três níveis de governo & Não & Sim \\
\hline Órgão Coordenador & Sim & Não \\
\hline Órgãos podem adaptar legislação & Sim & Não \\
\hline $\begin{array}{l}\text { Modalidades de licitação definidas } \\
\text { pela natureza do bem a ser } \\
\text { comprado }\end{array}$ & Sim & Não, exceto para modalidade pregão \\
\hline $\begin{array}{l}\text { Avaliação envolve apenas aspectos } \\
\text { legais }\end{array}$ & $\begin{array}{l}\text { Não, inclui participação de MPEs } \\
\text { entre outros }\end{array}$ & Sim \\
\hline $\begin{array}{l}\text { Margem de Preferência à Produção } \\
\text { Nacional }\end{array}$ & $\begin{array}{l}6 \% \text { para grandes empresas } \\
12 \% \text { para MPEs }\end{array}$ & Não existe \\
\hline Preferência às pequenas empresas & $\begin{array}{l}\text { Reserva MPEs de compras entre U\$ } \\
2,5 \text { mil e U\$ } 100 \text { mil; possibilidade } \\
\text { de reserva para MPEs acima de U\$ } \\
100 \text { mil. Destino de parcelas de } \\
\text { aquisições para participação } \\
\text { exclusiva de MPEs. Destino, como } \\
\text { oferta única, a empresas em HUB- } \\
\text { zones ou grupos sociais em } \\
\text { desvantagem de contratos de valor de } \\
\text { até U\$ } 5 \text { mi, no caso de bens } \\
\text { industriais, e de até U\$ } 3 \text { mi para } \\
\text { outros tipos de aquisições }\end{array}$ & $\begin{array}{l}\text { Não existiam. } \\
\text { A partir de 2007: } \\
\text { Margem de preferência de } 10 \% \text { (nas } \\
\text { licitações em geral) e } 5 \% \text { (pregão) } \\
\text { Possibilidade de reserva para MPEs de } \\
\text { compras de até R } \$ 80 \text { mil } \\
\text { Possibilidade de destino de parcelas de } \\
\text { aquisições para subcontratação ou } \\
\text { participação exclusiva de MPEs }\end{array}$ \\
\hline Acordos Internacionais & $\begin{array}{l}5 \text { acordos, entre eles GPA (OMC) e } \\
\text { NAFTA }\end{array}$ & $\begin{array}{l}\text { Nenhum, Mercosul está começando a } \\
\text { estabelecer protocolos }\end{array}$ \\
\hline$\%$ das MPEs & $20 \%$ & $\mathrm{Nd}$ \\
\hline$\%$ de fornecedores estrangeiros & $5 \%$ & $\mathrm{Nd}$ \\
\hline$\%$ de compras sem licitação & $\mathrm{Nd}$ & 48\% (média 1995-2004) \\
\hline
\end{tabular}

Quadro 1: Compras governamentais no Brasil e nos Estados Unidos

Fonte: Marques (2005, p. 41)

A União Europeia (UE) foi criada com o objetivo de ajudar as empresas europeias a tornarem-se mais inteligentes, mais inovadoras e mais sustentáveis. A UE é composta por 27 Estados-Membros, após a saída do Reino Unido em 2020, e, mesmo sendo Estados soberanos 
e independentes, estes países congregaram parte da sua soberania a fim de trabalharem em conjunto para ajudar as empresas e as indústrias a serem mais competitivas, gerar crescimento econômico e criar novos empregos (CAVEDO, 2020).

De acordo com Cavedo (2020), as políticas da UE são voltadas para o crescimento do comércio e da indústria e são vistas como um dos instrumentos de mercado a ser utilizado para (i) a promoção do crescimento inteligente e sustentável, (ii) a geração de empregos e (iii) maiores investimentos em inovação e desenvolvimento. A regulamentação europeia, em matéria de contratação pública, aplica-se a todos os contratos públicos com potencial interesse para os operadores que exercem a sua atividade no mercado interno, garantindo igualdade de acesso e concorrência equitativa em matéria de processos públicos.

Os contratos públicos são vistos como de papel fundamental, tendo, por isso, os seus instrumentos e métodos existentes modernizados de modo a acompanhar a evolução do contexto político, social e econômico do bloco. O Livro Verde é a geração atual de diretivas sobre contratos públicos na UE, e a sua regulamentação prevê procedimentos para que os processos de aquisição do setor público sejam conduzidos da forma mais racional, transparente e equitativa possível (CAVEDO, 2020).

Ainda segundo Cavedo (2020), a proposição da UE é utilizar os contratos públicos para melhorar o ambiente empresarial, especialmente para as micro e pequenas empresas inovadoras. A exemplo dos EUA, a União Europeia possui uma política de fomento à pequena e média empresa que busca reforçar o crescimento e a competitividade das MPEs, a chamada Small Business Act (SBA) for Europe.

\subsubsection{Busca pela eficiência nas Compras Públicas}

Os compradores públicos devem estar cientes do seu papel estratégico no processo de aquisição de materiais devido ao impacto dessa operação em relação aos demais processos que estão integrados à cadeia produtiva ou operativa das organizações (relação com os macroprocessos organizacionais). Este processo pode transformar-se em vantagem competitiva, desde que adequadamente desenvolvido e desempenhado na instituição (BATISTA; MALDONADO, 2008).

Nas compras públicas, a eficiência está relacionada com o que é entregue e com o que é consumido de recursos, ou seja, com a relação entre o cumprimento dos objetivos iniciais 
estipulados (adquirir determinado insumo na quantidade especificada, conforme os requisitos estipulados e pelo melhor preço) e os custos envolvidos para atingir o resultado da compra (no melhor tempo possível, com as atividades conduzidas de forma correta e seguindo os regramentos legais) (BATISTA; MALDONADO, 2008; BRASIL, 2009).

A Lei 8.666 aprovada em 1993 regulamenta o que diz a Constituição Federal sobre as normas relativas aos processos licitatórios e que, salvo exceções, obras, serviços e compras públicas devem ser feitos por meio de licitações (ADRIANO, 2013). O artigo 37 informa que a Administração Pública deve ser norteada pelos princípios fundamentais da legalidade, impessoalidade, moralidade, publicidade e eficiência (LIMPE), tendo o princípio da eficiência relação com a gestão da aplicação do recurso público (BRASIL, 1988).

A Figura 3 relaciona estes princípios constitucionais com os aspectos relativos à atuação dos servidores aplicada aos procedimentos licitatórios.

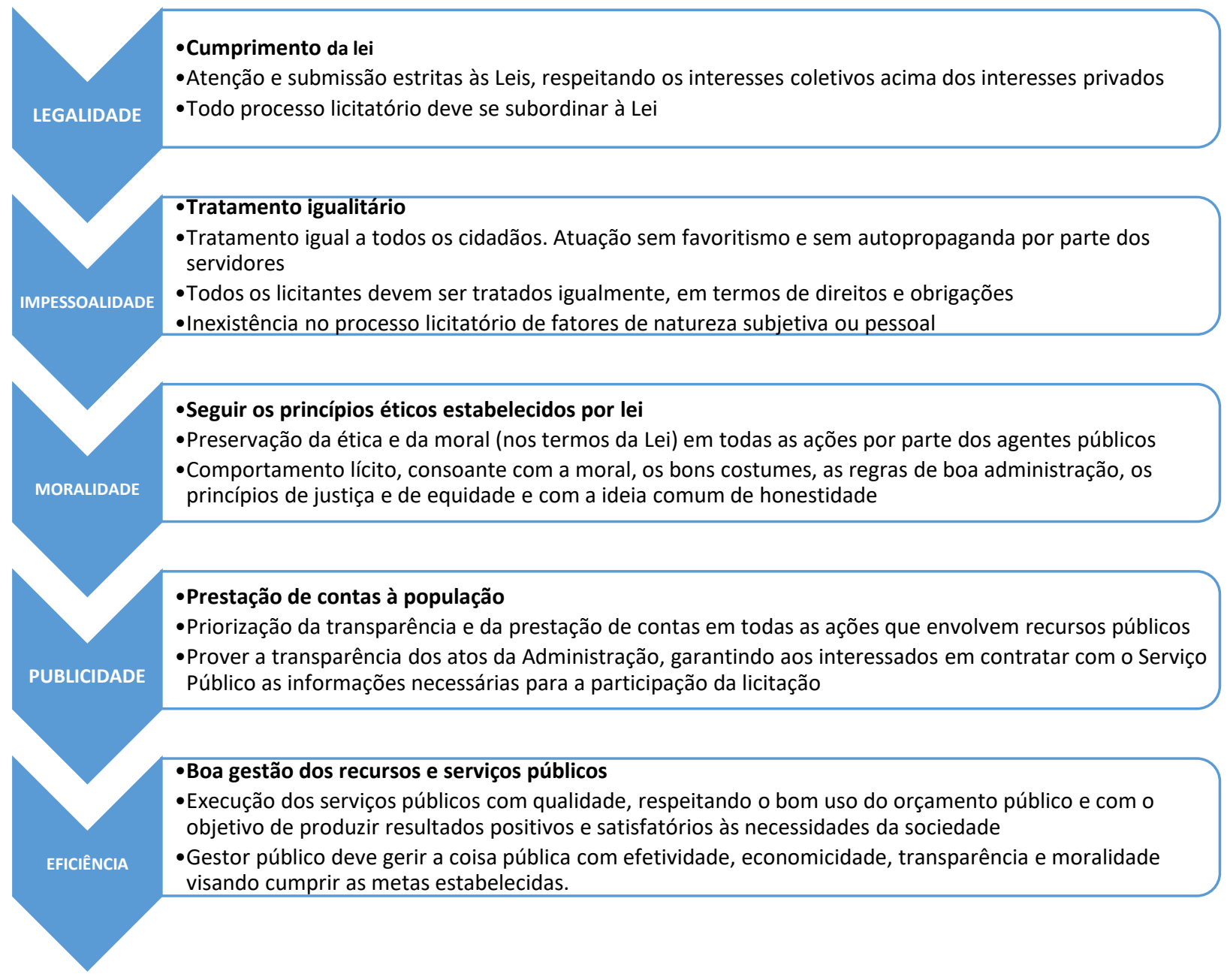

Figura 3: Princípios Constitucionais aplicáveis às Licitações

Fonte: elaborado pelo autor 
A preocupação com a melhoria da eficiência nas atividades públicas pode ser vista nas políticas estipuladas no Decreto 5378/05 que instituiu o GesPública, Programa Nacional de Gestão Pública e Desburocratização, criado basicamente com o objetivo de melhorar e desburocratizar o serviço público. O GesPública foi o resultado da evolução histórica de diversas iniciativas do Governo Federal para a promoção da gestão pública de excelência, visando contribuir para a qualidade dos serviços públicos prestados ao cidadão e para o aumento da competitividade do país (BRASIL, 2005).

As principais características do GesPública estão no fato de ele (i) ser essencialmente público (estar orientado ao cidadão e respeitar os princípios constitucionais do LIMPE), (ii) ser contemporâneo (alinhado ao estado da arte da gestão), (iii) estar voltado para a disposição de resultados para a sociedade (com impactos na melhoria da qualidade de vida e na geração do bem comum) e (iv) ser federativo (de aplicação em toda a Administração Pública, em todos os poderes e esferas do governo).

\subsection{AVAliaÇÃo DE DESEMPENHO}

A gestão dos níveis estratégicos, táticos e operacionais nas organizações se tornou um fator crítico de sucesso. O avanço da competitividade no ambiente empresarial torna ainda maior a necessidade de se medir o desempenho de uma organização tendo em vista os seus objetivos estratégicos. Os modelos de Sistemas de Medição de Desempenho Organizacional (SMDO) servem de base para as empresas medirem a sua performance operacional, permitindo que a empresa planeje, meça e controle o seu desempenho de acordo com a estratégia definida. Sua função é permitir que a empresa desempenhe melhor os seus negócios, e não somente conheça o seu desempenho. SMDO é definido como o conjunto de pessoas, processos, métodos, ferramentas e indicadores estruturados para coletar, descrever e representar dados com a finalidade de gerar informações sobre múltiplas dimensões de desempenho para os seus usuários em diferentes níveis hierárquicos, de forma a permitir que eles possam avaliar o desempenho das equipes, das atividades, dos processos e da própria organização, permitindo a adoção de decisões e execução de ações para a melhoria do desempenho organizacional (FIGUEIREDO et al., 2005).

A criação de um SMDO para avaliar o desempenho nas organizações não é um tema recente. Neste sentido, Figueiredo et al. (2005) afirmam que o sistema de avaliação de 
desempenho passou por três fases distintas: a primeira fase iniciou no século XIV e foi até o século XIX, quando as primeiras práticas de contabilidade com a finalidade de controlar os processos produtivos se originaram. A segunda fase se deu por volta do início do século XX, ocorrendo até meados da década de 1980, quando o processo de avaliação de desempenho foi formalmente integrado ao ciclo de planejamento e controle. A terceira etapa teve início durante a década de 1980, permanecendo até os dias atuais, quando diversas críticas foram feitas ao modelo tradicional e novos modelos foram propostos com várias dimensões.

\subsubsection{Modelos de avaliação de desempenho}

Müller (2014) apresenta alguns modelos de avaliação de desempenho, os quais apresentam características que podem se complementar na construção de um modelo de avaliação de desempenho genérico. Entre as diversas propostas, estão os seguintes modelos:

a) Modelos com ênfase financeira

- EVA - Economic Value Added

o TOC - Teoria das Restrições

b) Modelo clássico

o TQM - Gestão da Qualidade Total

c) Modelos estruturados

- BSC - Balanced Scorecard

o CI - Capital Intelectual

o PNQ - Prêmio Nacional para a Qualidade

d) Modelos específicos

o Modelo Quantum

o Rummler e Brache

o Sink e Tuttle

A avaliação de desempenho das organizações é feita classicamente sob o enfoque de resultados econômico-financeiros. Os modelos EVA e TOC se propõem a melhorar a avaliação, mantendo o foco nos aspectos econômico-financeiros. O modelo da qualidade total (TQM) é bastante difundido nas organizações brasileiras desde a década de 1980, criando a cultura da 
medição de desempenho naquelas que adotaram o modelo. Os chamados modelos estruturados são alguns que estão sendo discutidos nos últimos tempos e se caracterizam particularmente por proporem uma estrutura para a avaliação de desempenho. Já os modelos específicos, assim denominados por se tratar de propostas de empresas de consultoria, enfatizam, além de uma estruturação, aspectos voltados à implantação de um sistema de avaliação de desempenho (MULLER, 2014).

O TQM proporciona uma base operacional para a medição de desempenho, sendo seu uso o responsável por uma cultura de medição e melhoria contínua em toda a empresa e, portanto, o modelo mais indicado para este trabalho. O Quadro 2 traz um resumo dos modelos.

As organizações têm demonstrado interesse por novos modelos de SMDOs, entretanto, a grande maioria tem encontrado dificuldades para implementá-los. Pesquisadores e praticantes reconhecem a auto avaliação organizacional como uma das mais importantes práticas para disseminação e internalização de processos de mudança (FIGUEIREDO et al., 2005). 


\begin{tabular}{|c|c|c|c|}
\hline $\begin{array}{l}\text { Característica / } \\
\text { Critério de Análise }\end{array}$ & Principais elementos & Principais contribuições & Eventuais desvantagens \\
\hline Descrição & & Diferenciais do modelo & \\
\hline EVA & $\begin{array}{l}\text { MVA; } \\
\text { EVA; } \\
\text { FCD; } \\
\text { VPL; } \\
\text { Custo de Capital; } \\
\text { Banco de bônus. }\end{array}$ & $\begin{array}{l}\text { Foco único - simplicidade, } \\
\text { facilidade de disseminação, } \\
\text { mais EVA melhor; } \\
\text { Troca da visão contábil pela } \\
\text { econômica; } \\
\text { Banco de bônus; } \\
\text { Inexistência de tetos. }\end{array}$ & $\begin{array}{l}\text { Desencoraja } \\
\text { investimentos que não } \\
\text { cubram o custo do } \\
\text { capital e aqueles de } \\
\text { difícil justificativa } \\
\text { (retornos intangíveis); } \\
\text { Medidas financeiras são } \\
\text { consequência das } \\
\text { demais. }\end{array}$ \\
\hline TOC & $\begin{array}{l}\text { Medidas de resultado; } \\
\text { Medidas operacionais } \\
\text { globais; } \\
\text { Gargalos; } \\
\text { Melhoria contínua. }\end{array}$ & $\begin{array}{l}\text { Simplicidade; } \\
\text { Medida liga-desliga: caixa; } \\
\text { Pragmatismo. }\end{array}$ & \\
\hline TQM & $\begin{array}{l}\text { GPD; } \\
\text { Rotina; } \\
\text { Qualidade grande; } \\
\text { Ferramentas. }\end{array}$ & $\begin{array}{l}\text { Cultura da medição de } \\
\text { desempenho; } \\
\text { Ataque à questão no nível de } \\
\text { base - simplicidade das } \\
\text { ferramentas. }\end{array}$ & $\begin{array}{l}\text { Abordagem de baixo } \\
\text { para cima leva a excesso } \\
\text { de indicadores; } \\
\text { Apresenta visão de } \\
\text { processos } \\
\text { intrafuncionais. } \\
\end{array}$ \\
\hline BSC & $\begin{array}{l}\text { Perspectivas; } \\
\text { Objetivo, Indicador, } \\
\text { Meta e Iniciativa; } \\
\text { Mapa estratégico; } \\
\text { Indicador de resultado e } \\
\text { vetor de desempenho. } \\
\end{array}$ & $\begin{array}{l}\text { Estruturação; } \\
\text { Equilíbrio (balanceamento); } \\
\text { Mapa estratégico - relações de } \\
\text { causa-efeito. }\end{array}$ & Complexidade \\
\hline$\overline{\mathrm{CI}}$ & $\begin{array}{l}\text { Focos = perspectivas; } \\
\text { Tipos de capital } \\
\text { intelectual; } \\
\text { Business Navigator. } \\
\end{array}$ & $\begin{array}{l}\text { Preocupação com o futuro; } \\
\text { Ênfase na pessoa; } \\
\text { Îndices de inovação } \\
\text { tecnológica bem atuais. }\end{array}$ & $\begin{array}{l}\text { Dimensionamento - } \\
\text { número elevado de } \\
\text { indicadores. }\end{array}$ \\
\hline PNQ & $\begin{array}{l}\text { Critérios de excelência; } \\
\text { Sistema de pontuação e } \\
\text { premiação; } \\
\text { Perspectivas. } \\
\end{array}$ & $\begin{array}{l}\text { Incorporação de mais } \\
\text { perspectivas; } \\
\text { Força da pontuação e } \\
\text { premiação. }\end{array}$ & \\
\hline Quantum & $\begin{array}{l}\text { Matriz Quantum; } \\
\text { Geradores; } \\
\text { Facilitadores; } \\
\text { O processo em si; } \\
\text { Melhoria contínua. } \\
\end{array}$ & $\begin{array}{l}\text { Procedimento passo a passo: } \\
\text { Elementos facilitadores; } \\
\text { Visão explícita de processos } \\
\text { horizontais. }\end{array}$ & $\begin{array}{l}\text { Resume o desempenho } \\
\text { em somente três } \\
\text { dimensões básicas (C, Q } \\
\text { e T). }\end{array}$ \\
\hline Rummler e Brache & $\begin{array}{l}\text { Níveis: organização, } \\
\text { processos e pessoas. }\end{array}$ & $\begin{array}{l}\text { Procedimento passo a passo: } \\
\text { Visão explícita de processos } \\
\text { horizontais; } \\
\text { Diferenciação de indicadores } \\
\text { por cargo no nível das pessoas. }\end{array}$ & \\
\hline Sink e Tuttle & $\begin{array}{l}\text { Sete dimensões de } \\
\text { desempenho; } \\
\text { Estrutura de } \\
\text { relacionamento. }\end{array}$ & $\begin{array}{l}\text { Definição clara de alguns } \\
\text { conceitos; } \\
\text { Relacionamento entre } \\
\text { dimensões competitivas; } \\
\text { Incorporação de perspectivas } \\
\text { superiores à financeira. }\end{array}$ & $\begin{array}{l}\text { Ao usar sete dimensões } \\
\text { em vários processos, } \\
\text { pode levar ao excesso de } \\
\text { indicadores. }\end{array}$ \\
\hline
\end{tabular}

Quadro 2: Resumo dos modelos de avaliação de desempenho

Fonte: Müller (2014, p. 157) 


\subsubsection{Visão geral sobre Avaliação e Desempenho}

Para Slack et al. (2018), nenhuma operação existe ou funciona isoladamente. As decisões tomadas dentro de qualquer operação e a forma de realização de suas atividades afetarão os stakeholders - pessoas e grupos que têm algum interesse nas atividades produtivas. Os stakeholders podem ser tanto internos (funcionários) quanto externos (clientes, a sociedade, os acionistas da empresa, fornecedores) e a organização tem como responsabilidade entender os objetivos de seus stakeholders, de forma a permitir o estabelecimento adequado dos seus objetivos organizacionais. As operações realizadas pelas organizações necessitam ser medidas para verificar se a meta da organização está sendo atingida (GOLDRATT, 1994).

A adoção de medidas de desempenho é importante pelo fato de orientar os gestores na tomada de decisões. As medidas que estão alinhadas com as intenções estratégicas não só permitem avaliar se as estratégias estão de fato sendo implementadas como também contribuem para encorajar a adoção de um comportamento coerente com a estratégia (CORRÊEA, 2012).

O estabelecimento de um sistema de mensuração do desempenho, apesar de difícil e complexo, é útil, pois, ao se atingir equilíbrio entre algumas medidas-chave (diretas e simples, mas que podem não refletir a variedade dos objetivos organizacionais), pode-se obter muitas medidas detalhadas (complexas e difíceis de administrar) capazes de apresentar várias nuances do desempenho. O equilíbrio é alcançado quando há um vínculo claro entre a estratégia global da organização e os indicadores de desempenho mais importantes que refletem os objetivos estratégicos (SLACK et al., 2018).

Para Aligleri et al. (2016), os indicadores de desempenho são as medidas que têm como propósito monitorar as ações gerenciais de um processo, isto é, quantificar os resultados das ações com base na natureza e na especificidade do processo, permitindo (i) compreender, (ii) decidir com base em dados e fatos concretos, (iii) proporcionar objetividade de avaliação e (iv) incentivar mudanças. Para avaliar o desempenho das operações, os indicadores devem estar alinhados às estratégias produtivas. O processo de acompanhamento desses indicadores fornece um alerta prévio sobre questões e desdobramentos potencialmente prejudiciais e revela oportunidades. 
De acordo com Neely et al. (2005), existem várias maneiras pelas quais essas medidas de desempenho podem ser categorizadas; porém, a lógica está nas medidas de desempenho que precisam ser posicionadas em um contexto estratégico, pois influenciam o que as pessoas fazem. A medição pode ser o "processo de quantificação", mas seu efeito é estimular a ação, e isto se dá apenas por meio da consistência da ação que as estratégias são realizadas. A Figura 4 traz os aspectos de medidas de performance mais usuais em organizações manufatureiras.

\begin{tabular}{|c|c|c|c|}
\hline Qualidade & Tempo & Flexibilidade & Custo \\
\hline Desempenho & Lead time de fabricação & Qualidade do material & $\begin{array}{l}\text { Custo de } \\
\text { fabricação }\end{array}$ \\
\hline Características & $\begin{array}{l}\text { Taxa de introdução de } \\
\text { produtos }\end{array}$ & Qualidade da produção & Valor adicionado \\
\hline Confiabilidade & Lead time de entrega & Novos produtos & Preço de venda \\
\hline Conformidade & $\begin{array}{l}\text { Desempenho da data de } \\
\text { entrega }\end{array}$ & Modificação do produto & Custo operacional \\
\hline Durabilidade técnica & Frequência de entrega & Entregabilidade & Custo do serviço \\
\hline $\begin{array}{l}\text { Facilidade de } \\
\text { manutenção }\end{array}$ & & Volume & \\
\hline Estética & & Mix & \\
\hline Qualidade percebida & & Mix de recursos & \\
\hline \multicolumn{4}{|l|}{ Humanidade } \\
\hline Valor & & & \\
\hline
\end{tabular}

Figura 4: As dimensões de qualidade, tempo, custo e flexibilidade

Fonte: Adaptado de Neely et al. (2005, p. 1232)

Chiavenato (2014) propõe a concepção e o uso de monitoramento contínuo de um quadro de indicadores de desempenho para que ocorra a constante avaliação do alcance das metas estabelecidas de eficácia (alcance dos resultados), eficiência (a melhor relação dos recursos utilizados para alcançar os resultados) e efetividade (capacidade de os resultados promoverem os impactos esperados). Slack et al. (2018) apontam os cinco objetivos de 
desempenho - qualidade, velocidade, confiabilidade, flexibilidade e custo - como medidas de desempenho.

Os indicadores clássicos são os utilizados na medição da produtividade de um sistema ou operação. Outro importante indicador de processo refere-se à capacidade e é vinculado à taxa real de utilização do sistema em relação àquela para o qual ele foi projetado. A disponibilidade do processo produtivo em condições normais de operação também é utilizada, assim como a capacidade teórica, que pode ser entendida como a capacidade estimada quando o processo produtivo foi projetado. A eficiência também é um indicador relevante e contempla a relação existente entre capacidade efetiva e capacidade do sistema. Indicadores de sustentabilidade, como o consumo de matérias-primas, os tipos de materiais usados na produção, a embalagem dos principais produtos, o consumo de energia (quantidades e tipos usados) também podem ser utilizados.

Neely et al. (2005) definem avaliação de desempenho como o procedimento que mensura a eficiência e a eficácia de uma ação. Os termos eficácia e eficiência são usados nas organizações para identificar o quanto as ações contribuíram para o alcance das metas. A eficácia se refere à extensão da obtenção e atendimento dos requisitos do cliente, enquanto a eficiência é a medida de quão economicamente os recursos da empresa são utilizados para fornecer um determinado nível de satisfação ao cliente. A avaliação de desempenho trata de métodos para quantificar a eficiência e a eficácia das atividades de um negócio; é o processo de quantificação da ação, onde a medição é o processo de quantificação e a ação leva ao desempenho. Portanto, o nível de desempenho que uma empresa atinge é uma função da eficiência e eficácia das ações que realiza, e:

1. A medição de desempenho pode ser definida como o processo de quantificar a eficiência e eficácia da ação.

2. Uma medida de desempenho pode ser definida como uma métrica usada para quantificar a eficiência e/ou eficácia de uma ação.

Um sistema de medição de desempenho pode ser definido como o conjunto de métricas usado para quantificar a eficiência e a eficácia das ações. 


\subsubsection{Avaliação de Desempenho na Administração Pública}

A avaliação de desempenho não é aplicada somente em empresas privadas. As instituições públicas também necessitam adotar este mecanismo para melhorar o desenvolvimento das suas atividades. Mesmo com as suas peculiaridades, as empresas públicas também necessitam de uma estratégia bem definida, processos estruturados e indicadores que mostrem aos gestores informações sobre o desempenho da organização. Este fato decorre da necessidade de haver instrumentos de controle que possam auxiliar e direcionar os gestores em direção ao alcance das metas organizacionais. (FIGUEIREDO et al., 2005; MENESES, 2006).

Meneses (2006) demonstra a importância da integração entre o Planejamento Estratégico, a Avaliação de Desempenho e a Gestão por Processos em empresas de natureza privada e também em empresas de natureza pública e do alinhamento de todos os processos da organização com a estratégia, bem como do acompanhamento da evolução desses processos na relação com o alcance das metas que levarão ao atendimento dos objetivos estratégicos. Para Figueiredo et al. (2005), o sistema de avaliação de desempenho precisa fornecer informações aos gestores que os auxiliem a perceber se a estratégia está sendo executada conforme o planejado e se ela continua sendo viável ao desenvolvimento da organização.

A avaliação de desempenho também decorre da necessidade da sociedade enquanto usuária do sistema público, na medida em que existe a expectativa de que o gestor aplique de forma correta os recursos públicos e atenda aos anseios da população e a necessidade da adoção de um instrumento que sirva como balizador para a tomada de decisão. No ambiente público, a reformulação para a gestão estratégica com base em resultados partiu do Ministério do Planejamento, Orçamento e Gestão (MPOG), como a divulgação de um instrumento de auto avaliação segundo as dimensões de efetividade, eficácia e eficiência da gestão pública através do Programa Nacional de Gestão Pública e Desburocratização (GESPÚBLICA) instituído pelo Decreto 5.378/2005 segundo Souza et al. (2020). Apesar da revogação do Programa GESPÚBLICA a partir da publicação do Decreto 9.094/17 (BRASIL, 2017), os conceitos das práticas voltadas para a qualificação da gestão pública com focos na geração de resultados para o cidadão permanecem relevantes.

Conforme Hoffmann e Filho (2017), os cidadãos têm demandado cada vez mais que os agentes públicos informem os resultados das ações realizadas no decorrer da condução das instituições públicas. Esta consciência social tem exigido que administradores públicos estejam 
cada vez mais dispostos a prestar contas de suas gestões, apresentando relatórios sobre os resultados que suas ações geraram. A Administração Pública, que anteriormente estava voltada para a gestão dos processos, precisa pautar-se por uma gestão voltada para os resultados. Essa mudança de paradigma ocorreu no Brasil a partir da Reforma Gerencial da Administração Pública, que ocorreu no primeiro mandato do presidente Fernando Henrique Cardoso. Uma das formas de manifestação prática dessa obrigação de prestar contas é medir os resultados das ações e programas governamentais, o que pode ocorrer mediante utilização de indicadores de desempenho.

Souza et al. (2020) afirmam que a gestão estratégica se tornou peça-chave que evolui para a performance management como um processo de gerenciamento para resultados, reunindo a prática de mensuração de resultados com as práticas governamentais do setor público e do planejamento estratégico. O controle das suas ações, alinhado com os objetivos estruturados em conhecimentos, cria uma aplicação sustentável de recursos públicos voltados para a criação de valores organizacionais que contemplam a eficiência e eficácia.

Hoffmann e Filho (2017) apontam que o uso de indicadores é um modo eficiente de gerir o Estado, visto que o uso dos mesmos permite que haja um efetivo controle sobre os resultados alcançados pela Administração Pública, contribuindo com a transparência das informações sobre as ações governamentais. Segundo Lemos et al. (2020), a utilização de indicadores de desempenho ajuda no gerenciamento organizacional. Todos os dados fornecidos por meio destes indicadores contribuem para mensurar o desempenho dos objetivos estratégicos da organização, além de servir como guia no processo que envolve as tomadas de decisões.

A Administração Pública vem sofrendo, por parte dos usuários dos serviços públicos e, principalmente, por parte dos órgãos de controle, pressão por uma maior profissionalização dos servidores públicos. Além de buscar a qualificação nos seus quadros de servidores, novos conceitos de gestão estão sendo incorporados às práticas de gestão pública, visando o aumento da eficiência, eficácia e efetividade de seus serviços, bem como uma melhor atenção ao cidadão e à sociedade. Na condição de usuários de seus serviços, a preocupação principal deve ser o bom atendimento das necessidades da sociedade (ADRIANO, 2013).

De acordo com Lemos et al. (2020), os indicadores têm a função de descrever, por meio da geração de informações, o estado real dos acontecimentos e o seu comportamento e analisar as informações presentes com base nas anteriores, de forma a realizar proposições 
valorativas. Pode-se considerar uma gestão eficaz aquela que alcança resultados, ou seja, atende demandas, interesses e as expectativas dos beneficiários (cidadãos ou organizações).

Na gestão pública, os indicadores são instrumentos que contribuem para identificar e medir aspectos relacionados a um determinado fenômeno decorrente da ação ou da omissão do Estado. Conforme Brasil (2012), o objetivo por trás do uso dos indicadores é o de assistir os gestores públicos. Ao possuírem informações confiáveis, precisas e tempestivas, os mesmos podem abdicar de decisões fundamentadas exclusivamente na intuição, tradição, "tino administrativo" ou opiniões pessoais. Assim, neste contexto, os indicadores permitem integrar a subjetividade e a objetividade a partir de evidências empíricas, viabilizam comparações e avaliações consistentes, e, principalmente, criam condições para esclarecer e fornecer suporte às decisões.

Hoffmann e Filho (2017) reforçam que, com a posse de indicadores de desempenho apropriados, o gestor público passa a contar com uma boa ferramenta de suporte à tomada de decisão. Também, os autores apontam que o cidadão passa a dispor de uma maior capacidade de exercer o controle sobre o desempenho do gestor público, apresentando, então, uma dupla vantagem sobre o uso de indicadores: por um lado, auxilia o gestor público na tomada de decisão; por outro, permite que o cidadão tenha condições efetivas de mensurar os resultados destes gestores.

A principal finalidade de um indicador é traduzir, de forma mensurável, um aspecto da realidade dada ( situação social) ou construída (ação), de maneira a tornar operacional a sua observação e avaliação. Em suma, indicadores são informações que permitem descrever, classificar, ordenar, comparar ou quantificar de maneira sistemática aspectos de uma realidade e que atendem às necessidades dos tomadores de decisões. Se um indicador não reflete a realidade que se deseja medir ou não é considerado nos diversos estágios da elaboração e implementação de políticas, planos e programas, pode-se constatar um desperdício de tempo e recursos públicos (BRASIL 2012).

Segundo entendimento do TCU (2020), o desempenho de um determinado resultado pode ser medido por meio da utilização de quatro dimensões de análise: economicidade, eficiência, eficácia e efetividade, podendo, para cada dimensão de análise, existir um ou mais indicadores que possam ser usados na modelagem de indicadores de desempenho das ações ou processos realizados pelas organizações públicas, conforme o Quadro 3. 


\begin{tabular}{|c|c|}
\hline Dimensão & Definição \\
\hline Economicidade & $\begin{array}{l}\text { Mede os gastos envolvidos na obtenção dos insumos (materiais, humanos, } \\
\text { financeiros etc.) necessários às ações que produzirão os resultados } \\
\text { planejados. Visa minimizar custos sem comprometer os padrões de } \\
\text { qualidade estabelecidos e requer um sistema que estabeleça referenciais de } \\
\text { comparação e negociação; }\end{array}$ \\
\hline Eficiência & $\begin{array}{l}\text { Medida que possui estreita relação com produtividade, ou seja, o quanto se } \\
\text { consegue produzir com os meios disponibilizados. Assim, a partir de um } \\
\text { padrão ou referencial, a eficiência de um processo será tanto maior quanto } \\
\text { mais produtos forem entregues com a mesma quantidade de insumos, ou os } \\
\text { mesmos produtos e/ou serviços sejam obtidos com menor quantidade de } \\
\text { recursos; }\end{array}$ \\
\hline Eficácia & $\begin{array}{l}\text { Aponta o grau com que um Programa atinge as metas e objetivos planejados, } \\
\text { ou seja, uma vez estabelecido o referencial (linha de base) e as metas a } \\
\text { serem alcançadas, utiliza-se indicadores de resultado para avaliar se estas } \\
\text { foram atingidas ou superadas; }\end{array}$ \\
\hline Efetividade & $\begin{array}{l}\text { Mede os efeitos positivos ou negativos na realidade que sofreu a } \\
\text { intervenção, ou seja, aponta se houve mudanças socioeconômicas, } \\
\text { ambientais ou institucionais decorrentes dos resultados obtidos pela política, } \\
\text { plano ou programa. É o que realmente importa para efeitos de transformação } \\
\text { social. }\end{array}$ \\
\hline
\end{tabular}

Quadro 3: Indicadores para dimensões de análise de desempenho

Fonte: TCU (2020, p.15)

Em Brasil (2009), o modelo de desempenho chamado de 6Es do Desempenho é usado como referência para mensuração do desempenho das compras públicas. O desempenho é visto como um elemento de governança, sendo a conjunção dos esforços que geram os resultados para a cadeia de valor (o cidadão usuário do serviço público) e tendo como constituição duas dimensões: a de esforço e a de resultado, que por sua vez, são desdobradas em outras dimensões do desempenho. As dimensões de esforço são economicidade, execução e excelência; e as dimensões de resultado são eficiência, eficácia e efetividade, conforme ilustra a Figura 5. 


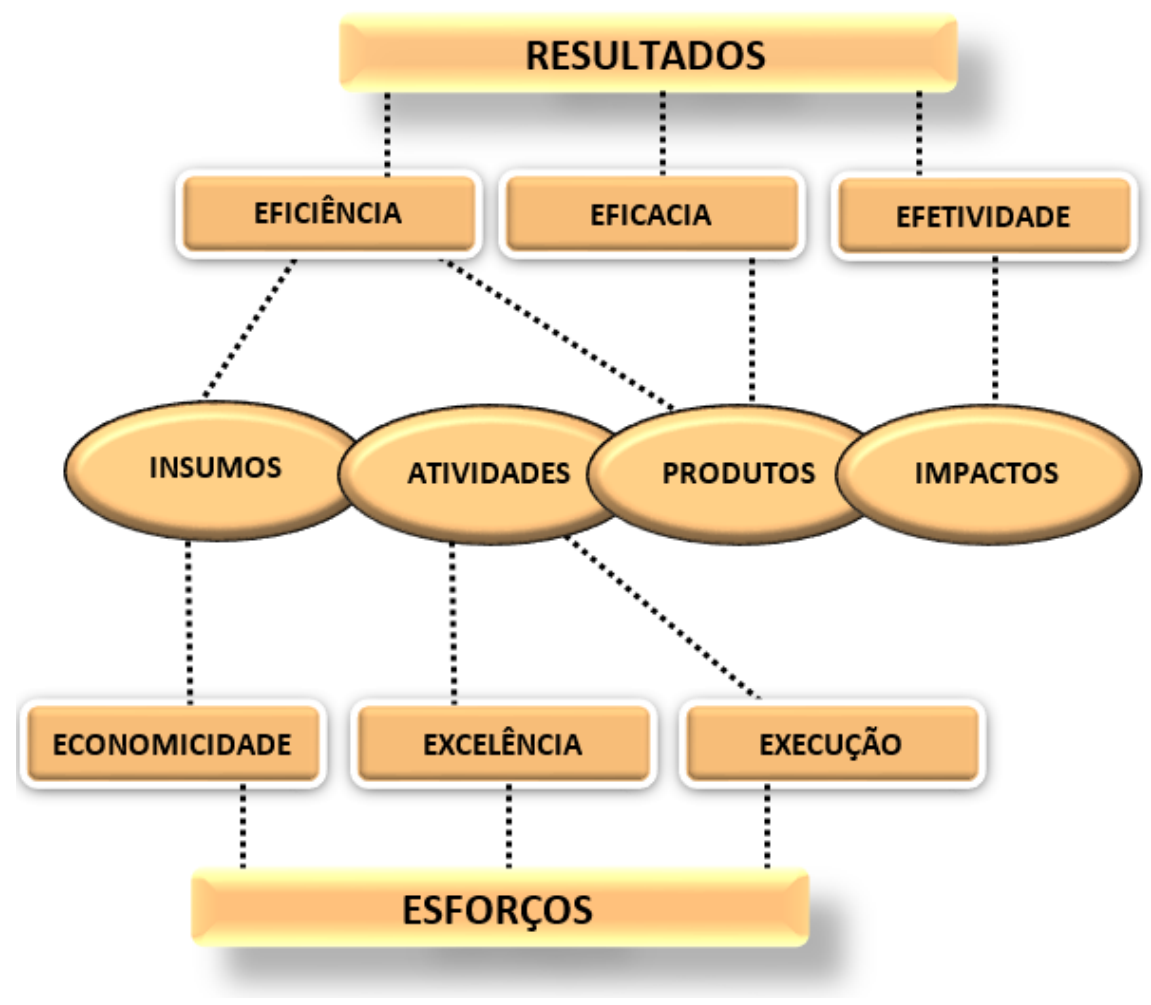

Figura 5: Modelo dos 6Es do Desempenho

Fonte: Adaptado de BRASIL (2009, p. 19)

A definição de cada dimensão, utilizando Brasil (2009), pode ser vista como:

a) Efetividade está relacionada aos impactos (primários, secundários ou finais) no contexto do esforço despendido na atuação para se alcançar um resultado que gere valor público.

b) Eficácia está relacionada aos produtos entregues aos beneficiários diretos no que se refere à sua quantidade, qualidade e cobertura.

c) Eficiência é a relação entre os produtos gerados (outputs) e os insumos empregados, usualmente sob a forma de custos ou produtividade.

d) Execução refere-se à realização das atividades programadas sob a forma de processos, projetos ou eventos.

e) Excelência é a conformidade a critérios e padrões de qualidade para a realização dos processos, atividades e projetos. 
f) Economicidade está relacionada à aquisição vantajosa e ao uso racional de recursos dentro dos requisitos de qualidade exigidos.

Apesar de a notação do TCU ser diferente da notação usada por vários outros autores, este trabalho usará a linguagem e os conceitos adotados pelo TCU, tendo em vista que a aplicação deste trabalho está centrada no uso em um órgão da Administração Pública federal, bem como por proporcionar uma facilidade na forma de comunicação dos demais órgãos públicos junto ao próprio TCU.

Neste trabalho, o termo "aspectos" refere-se ao conjunto de variáveis usadas com o propósito de representar a realidade (ou os aspectos da realidade que se pretende representar, e que podem ser vistos/definidos/medidos de forma quantitativa ou qualitativa, por meio de indicadores), sendo que a conceituação dos indicadores como um instrumento de mensuração quantitativa ou qualitativa de aspectos do desempenho não será adotada neste trabalho. A opção adotada segue a definição de TCU (2020), na qual um indicador de desempenho é um número, uma porcentagem ou uma razão que mede um aspecto do desempenho, com o objetivo de comparar esta medida com metas preestabelecidas.

Conforme Brasil (2009), um modelo pode ser usado para a formulação de indicadores através da execução de um conjunto de passos que são considerados necessários para assegurar que os princípios da qualidade e do sistema de medição do desempenho estejam em conformidade com o esperado pela organização. Os passos são:

1. Identificação do nível, dimensão, subdimensão e objetos de mensuração;

2. Estabelecimento dos indicadores de desempenho;

3. Validação preliminar dos indicadores com as partes interessadas;

4. Construção de fórmulas e estabelecimento de metas e notas;

5. Definição de responsáveis;

6. Geração de sistemas de coleta de dados;

7. Ponderação e validação final dos indicadores com as partes interessadas;

8. Mensuração dos resultados; 
9. Análise e interpretação dos indicadores; e

10. Comunicação do desempenho e gestão da mudança.

A Figura 6 apresenta o desdobramento das etapas nos passos correspondentes.

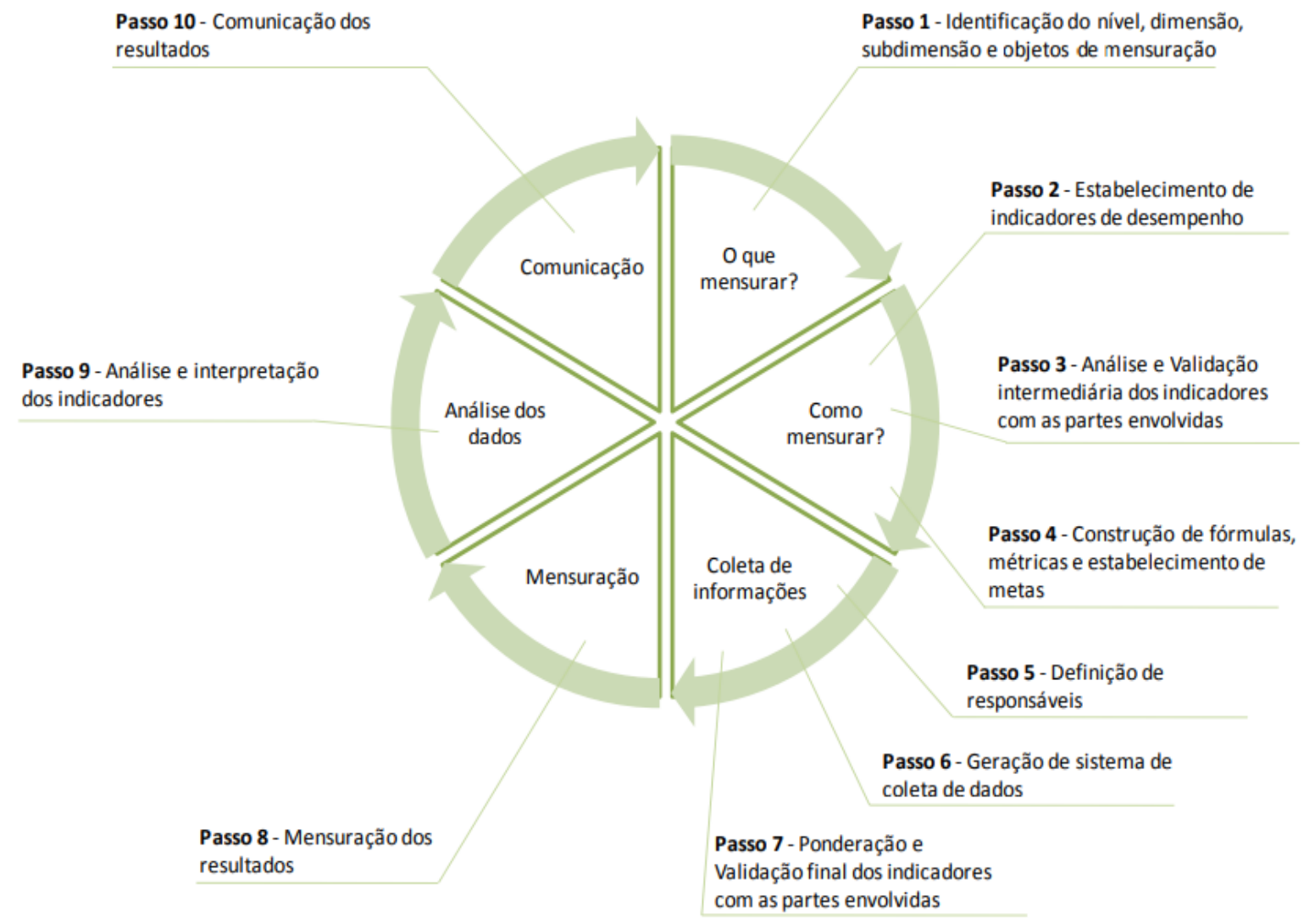

Figura 6: Etapas de medição e os 10 passos para a construção de indicadores

Fonte: Brasil (2009, p. 41)

O desdobramento destes passos é assim definido segundo Brasil (2009):

- O modelo proposto inicia pela identificação do nível, que se refere ao local na estrutura da Administração Pública onde o indicador será modelado, podendose usar os níveis macro (Governo), meso (política pública ou setor de governo), meso-micro (redes de organizações), micro (organização) e nano (unidade de organização). Na sequência, os objetos de mensuração, que tratam da definição precisa e clara daquilo que será mensurado, e a subdimensão, que procura explorar as medidas possíveis e cabíveis de serem extraídas a partir do objeto de mensuração escolhido ao identificar qual o tipo de medida é mais importante de ser mensurado para o objeto de mensuração, são identificados em conjunto com 
as dimensões, que se referem ao uso das 4 (quatro) dimensões de análise: economicidade, eficiência, eficácia e efetividade.

- Para o estabelecimento dos indicadores, deve-se definir os componentes básicos de um, sendo eles: (i) medida, (ii) fórmula, (iii) índice, (iv) padrão de comparação e (v) meta. Também deve-se considerar um conjunto de critérios básicos para garantir a posterior operacionalização da medição, levando-se em conta: (i) seletividade ou importância, (ii) simplicidade e clareza, (iii) representatividade, (iv) facilidade de análise, (v) comparabilidade, (vi) estabilidade e (vii) custo-efetividade. A definição destes termos está demonstrada no Quadro 4.

- A validação dos indicadores é realizada com as partes interessadas, sendo fundamental para a obtenção de um conjunto significativo de indicadores que propicie uma visão global da organização e que represente o desempenho da mesma.

- Definido o conjunto de indicadores e tendo eles sido analisados à luz dos critérios estabelecidos previamente, a construção das fórmulas e estabelecimento de metas e notas podem ser iniciados.

- Após a construção das fórmulas e do estabelecimento das metas, deve-se definir os responsáveis pela apuração do indicador, sendo necessária a indicação de um responsável pela geração e divulgação dos resultados obtidos de cada indicador.

- A coleta de dados determinará os requisitos para o levantamento das informações sobre os indicadores através da definição dos meios para a coleta destas informações.

- As partes interessadas são reunidas para deliberar sobre a ponderação e a validação final dos indicadores. Este passo é visto como fundamental para a obtenção de um quadro de indicadores relevantes e legítimos na representação do desempenho e da visão global da organização.

- Medir o que se deseja torna-se necessário após a execução dos passos anteriores. Aqui é iniciada a coleta efetiva dos dados e realizado o cálculo do indicador, procedendo-se com a conversão do valor obtido na nota correspondente. 


\begin{tabular}{|c|c|}
\hline Componentes & Critérios básicos \\
\hline $\begin{array}{l}\text { (i) medida ou grandeza qualitativa e } \\
\text { quantitativa que permite classificar as } \\
\text { características, os resultados e as } \\
\text { consequências. }\end{array}$ & $\begin{array}{l}\text { (i) seletividade ou importância: as informações devem } \\
\text { dizer respeito às principais variáveis estratégicas e às } \\
\text { prioridades definidas pela organização. }\end{array}$ \\
\hline $\begin{array}{l}\text { (ii) fórmula ou padrão matemático que } \\
\text { expressa a realizaçãa do cálculo. }\end{array}$ & $\begin{array}{l}\text { (ii) simplicidade, clareza, inteligibilidade e } \\
\text { comunicabilidade dos indicadores (a mensagem e o } \\
\text { significado devem ser levados para o público } \\
\text { interessado). }\end{array}$ \\
\hline $\begin{array}{l}\text { (iii) índice ou valor de um indicador em } \\
\text { determinado momento. }\end{array}$ & $\begin{array}{l}\text { (iii) representatividade, confiabilidade e sensibilidade } \\
\text { (capacidade de demonstrar a etapa mais importante e } \\
\text { crítica de um processo; os dados devem ser precisos, } \\
\text { capazes de responder aos objetivos e coletados de forma } \\
\text { correta na fonte de dados). }\end{array}$ \\
\hline $\begin{array}{l}\text { (iv) padrão de comparação que é o índice } \\
\text { aceitável de avaliação comparativa. }\end{array}$ & $\begin{array}{l}\text { (iv) investigativos: os dados devem ser fáceis de analisar, } \\
\text { para registro ou para reter informações e permitir } \\
\text { elaborar juízos de valor; }\end{array}$ \\
\hline \multirow[t]{3}{*}{$\begin{array}{l}\text { (v) meta ou orientação sobre o padrão de } \\
\text { comparação a ser alcançado. }\end{array}$} & $\begin{array}{l}\text { (v) indicadores devem ser facilmente comparáveis com } \\
\text { as referências internas ou externas, bem como séries } \\
\text { históricas de acontecimentos. }\end{array}$ \\
\hline & $\begin{array}{l}\text { (vi) estabilidade: procedimentos gerados de forma } \\
\text { sistemática e constante, sem muitas alterações e } \\
\text { complexidades, uma vez que é relevante manter o padrão } \\
\text { e permitir a série-histórica. }\end{array}$ \\
\hline & $\begin{array}{l}\text { (vii) custo-efetividade: projetado para ser factível e } \\
\text { economicamente viável. Os benefícios em relação aos } \\
\text { custos devem satisfazer todos os outros níveis. Nem } \\
\text { todas as informações devem ser mensuradas, é preciso } \\
\text { avaliar os benefícios gerados em detrimento do ônus } \\
\text { despendido. }\end{array}$ \\
\hline
\end{tabular}

Quadro 4: Definição dos componentes e critérios básicos para formulação de indicadores

Fonte: Elaborado pelo autor

- O próximo aspecto primordial no processo é a análise e a interpretação dos dados, pois a simples existência de uma sistemática de monitoramento e avaliação não proporciona ganhos e benefícios para a organização se não houver uma análise das informações.

- A etapa de comunicar o desempenho envolve o esforço de transmitir o máximo de informação no menor tempo, podendo ser concebidos quadros para a 
disponibilização de um conjunto relevante de indicadores na forma de gráficos e tabelas com sinalizadores, de modo que as informações sobre o desempenho possam ser repassadas às partes interessadas.

Iniciativas de organizações públicas, no sentido de avaliar o desempenho dos seus processos de compras, podem ser identificadas na literatura. Considerando que bens, obras e serviços são adquiridos pelo setor de compras, torna-se essencial avaliar o desempenho no contexto das compras públicas.

Araújo (2020) propôs um modelo para apoiar a gestão da Unidade de Licitações no processo de compras do Hospital Universitário Professor Polydoro Ernani de São Thiago, da Universidade Federal de Santa Catarina, por meio da criação de um instrumento com 14 indicadores qualitativos de desempenho que permitem avaliar o desempenho do processo licitatório, possibilitando o efetivo acompanhamento das atividades desenvolvidas pelo setor, que conduz à gestão eficiente e à melhor aplicação dos recursos públicos. Levando em conta a complexidade do problema e os interesses conflitantes dos agentes públicos, este instrumento de gestão permitiu ao gestor público avaliar o desempenho da unidade encarregada dos processos licitatórios, bem como auxiliou com informações específicas para a tomada de decisão.

Cavedo (2020) investiga e analisa a eficiência do sistema de compras da Universidade de Brasília, verificando quais foram as medidas adotadas pela UnB para a otimização das compras e a economicidade dos gastos e procurando cooperar com novas perspectivas que dizem respeito às compras realizadas pela Universidade em busca do ganho de eficiência. $\mathrm{O}$ contexto de escassez de recursos financeiros torna necessária a maior racionalidade na utilização dos recursos por parte dos gestores públicos; ainda, a demanda pulverizada sobre os mais diversos grupos de materiais e projetos de pesquisas (decorridos das atividades fins de ensino e pesquisa da universidade) geram diversas demandas imprevisíveis que culminam em dificuldades no planejamento das compras, tornando necessário o uso de alguma forma de medição e análise das atividades do processo.

Ensslin et al. (2015) analisaram um setor do Tribunal de Justiça de Santa Catarina para desenvolver um modelo de avaliação de desempenho que possibilite o acompanhamento das atividades realizadas neste setor de forma a dispor de um instrumento de apoio à decisão que seja apto a realizar o acompanhamento das atividades realizadas pelo setor, a disseminar as 
informações do que está sendo executado e a integrar e priorizar as ações que impactam positivamente no desempenho da área e da organização, integrando os aspectos do contexto julgados relevantes pelo decisor, medindo em que grau dado interesse é alcançado e gerando um procedimento para melhorar o desempenho organizacional.

Como meio de apoiar a gestão administrativa, de forma a fornecer o suporte necessário ao gestor para a tomada de decisão, Eiriz et al. (2016) avaliaram os serviços de licitação de um órgão público municipal propondo o uso de um modelo de avaliação pautado em 24 indicadores de desempenho que possibilitam o acompanhamento das atividades desenvolvidas pelo órgão público, permitindo uma gestão mais eficiente e com melhor aplicação dos recursos públicos disponíveis. O modelo construído contribuiu para apoiar a gestão do processo de compras do órgão público avaliado, na medida em que proporcionou uma visão detalhada dos pontos fortes e oportunidades de melhoria.

Esta seção tratou dos aspectos relativos à avaliação de desempenho, processo de análise que é adotado para realizar o acompanhamento das atividades, ações e decisões gerenciais adotadas ao comparar os resultados apresentados com os planejados pela organização. Mas, para uma melhor utilização, antes da sua adoção é necessário compreender o funcionamento da organização através do conhecimento dos processos e das atividades principais desempenhadas pela organização através de uma visão sistêmica que aborde toda a organização. O BPM, tema da próxima seção, se propõe a auxiliar nesse entendimento e no conhecimento do gerenciamento de um negócio através do controle de processos.

\subsection{BPM}

O gerenciamento de processos de negócio (BPM - Business Process Management) tem se consolidado como uma importante área do conhecimento no meio acadêmico e uma prática cada vez mais comum no meio empresarial. Inicialmente impulsionada pelo movimento da qualidade total e reforçada pelo movimento da reengenharia nas décadas de 1980 e 1990, o BPM ganhou força com a evolução da tecnologia da informação, abrindo a possibilidade de as empresas integrarem seus sistemas de informação tendo como pré-requisito para o funcionamento eficiente a análise e o redesenho de processos. É considerado uma fonte de melhoria na busca da eficiência e da eficácia dos negócios, embora sua implementação correta 
seja um grande desafio para a maioria das organizações (BORGES et al., 2016; BEZERRA et al., 2018).

Adotado por muitas organizações, o BPM, no entanto, ainda está em seu estágio inicial de implantação em organizações públicas e muitas questões ainda precisam ser entendidas por meio do conhecimento dos seus princípios e dos fundamentos que alicerçam a metodologia.

\subsubsection{Processos}

$\mathrm{O}$ atual dinamismo das organizações e a crescente exigência dos clientes por altos padrões de qualidade induzem os gestores a buscar o diferencial em novos modelos de gestão. Com o avanço dos métodos de gestão empresarial e a facilidade de obter informações, as organizações estão buscando especializações que possam reduzir ao máximo o tempo ocioso, aumentar a qualidade e atingir um alto padrão de eficiência e eficácia em suas atividades. É necessário que as organizações busquem um modelo de processo adequado e compatível com sua visão estratégica (GOMES, 2020). Os modelos baseados em processos vêm ganhando destaque no cenário organizacional em geral.

Todo trabalho importante realizado nas empresas faz parte de algum processo e não existe um produto ou um serviço ofertado por uma organização sem um processo empresarial, assim como não faz sentido existir um processo empresarial que não ofereça um produto ou um serviço (GOLÇALVES, 2000). As organizações fornecem os meios para atender às necessidades das pessoas, e o desempenho das mesmas é importante para seus clientes e usuários, funcionários, acionistas, fornecedores e comunidade. Para atender a todas essas expectativas, as organizações precisam ser administradas (processo de tomar decisões que faz as organizações serem capazes de utilizar corretamente seus recursos e atingir seus objetivos em geral), lidando com os problemas que surgem e tomando decisões para resolver problemas do presente e do futuro (MAXIMIANO, 2006).

Um processo é o conjunto de atividades realizadas na geração de resultados para o cliente, desde o início do pedido até a entrega do produto. Conforme Harrington (1993, p. 10), "processo é qualquer atividade que recebe uma entrada (input), agrega-lhe valor e gera uma saída (output) para um cliente interno ou externo, fazendo uso dos recursos da organização para gerar resultados concretos". Da mesma forma, Charlene e Murray (1994) partem da premissa que todo processo é uma série de etapas que transformam o resultado ou o produto à medida 
que este percorre a sequência de tarefas ou funções; um processo pode ser visto como um grupo de atividades realizadas numa sequência lógica com o objetivo de produzir um bem ou um serviço que tem valor para um grupo específico de clientes.

O processo produtivo está ligado ao uso das informações e recursos de conversão que utilizam insumos e os transformam em produtos finais de maior valor do que os insumos de entrada (materiais, componentes, energia, pessoal, capital). Entendido como o conjunto de tarefas unidas por um fluxo de bens e de informações devidamente coordenado com um propósito de modificar o estado e/ou a composição física de algo que entrou no processo, tomando um input, agregando valor e resultando em um output de valor econômico útil para atender às necessidades de um cliente em particular (ALIGLERI et al., 2016).

Empresas são organizações sociais, organismos vivos que funcionam como sistemas. Sistema é um conjunto integrado de partes inter-relacionadas que existem para atingir um determinado objetivo ou cumprir um determinado propósito, formado por órgão, departamento ou subsistema, cada qual especializado em uma determinada atividade (CHIAVENATO, 2014).

Chiavenato (2014) elenca os principais componentes de um sistema, eles sendo: as (i) entradas (inputs) ou insumos (qualquer recurso que alimente o sistema, vindo do ambiente externo; aquilo que ingressa em um sistema, podendo ser energia, informação, matériasprimas); as (ii) saídas (outputs) ou resultados (aquilo que o sistema produz e devolve ao ambiente externo); o (iii) processamento (throughput) ou transformação (o trabalho que o sistema realiza a partir das entradas para poder proporcionar as saídas); a (iv) retroação (feedback) ou realimentação (a influência que as saídas do sistema exercem sobre as suas entradas no sentido de ajustá-las ou regulá-las), podendo ocorrer a retroação positiva, que aumenta as entradas, ou a retroação negativa, que diminui as entradas, mantendo o equilíbrio do sistema, conforme a Figura 7.

Segundo Slack et al. (2018), os outputs dos processos de produtos e dos serviços são diferentes: enquanto os produtos são coisas tangíveis, os serviços são atividades ou processos que acontecem apenas quando são consumidos ou usados pelo cliente e que não podem ser estocados. Portanto, entende-se que não há como desenvolver um produto ou serviço sem que os mesmos passem por algum tipo de processo em sua fabricação, visto que todo o trabalho importante realizado em qualquer empresa faz parte de algum processo. 


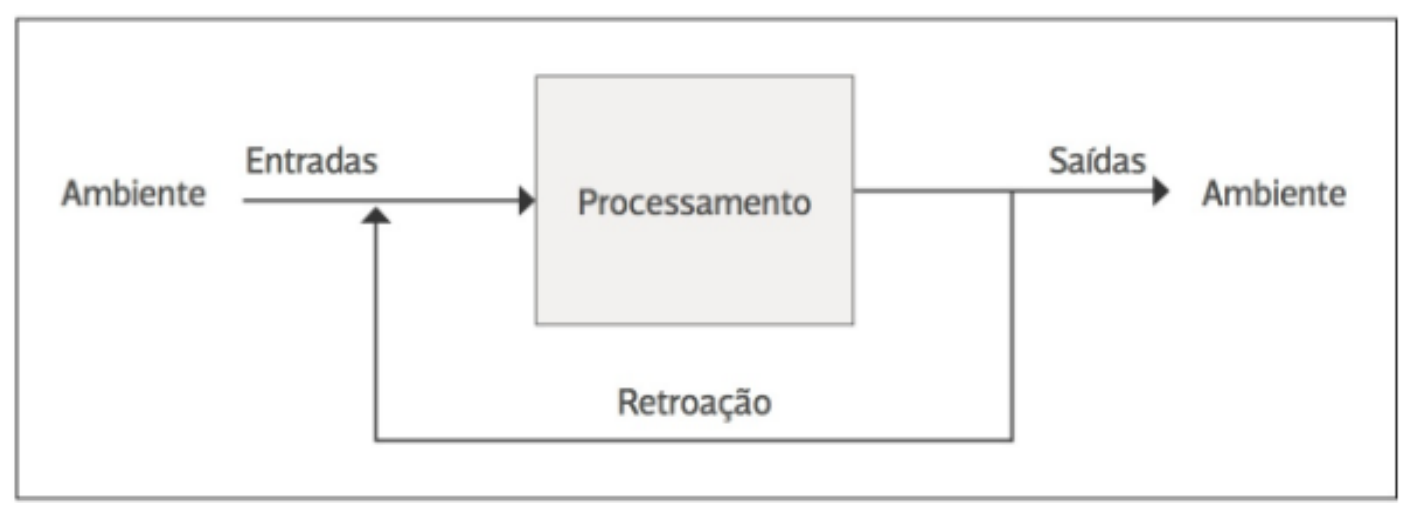

Figura 7: O sistema e seus componentes

Fonte: Chiavenato (2014, p. 67)

Para Müller (2014), o mapeamento dos processos é a principal ferramenta para entender os processos realizados através do uso de representação visual das atividades nas diversas funções da organização, oportunizando a identificação de oportunidades de simplificação. Para o autor, o mapeamento de processo permite: (i) definir as atividades-chave e medidas de desempenho; (ii) visualizar onde e por que os recursos são consumidos; (iii) identificar oportunidades de melhoria; (iv) servir de base para o treinamento; (v) comunicar o que está acontecendo (monitoramento) e (vi) ter uma visão de como suas tarefas se engajam em processos mais gerais. Para o autor, é preciso definir os limites inicial e final, ou seja, onde qualquer processo começa e onde o mesmo termina, antes de iniciar o seu detalhamento, sendo necessário que estejam definidos de forma clara para evitar sobreposições ou falta de responsabilidade.

Müller (2014) afirma que a manutenção da competitividade depende do alinhamento da organização com a estratégia adotada, sendo que um sistema de avaliação de desempenho precisa conduzir os processos da empresa com os objetivos e estratégias, servindo como elo de ligação entre os objetivos e a execução prática das atividades nas organizações. Além disso, a medição dos processos e dos resultados, bem como a sua comparação com os objetivos predeterminados, é de vital importância. A avaliação de desempenho parte do pressuposto de que os objetivos organizacionais devem ser traduzidos em sistemas de controle e operacionalizados através de indicadores, ou seja, com fórmulas ou regras que permitam a quantificação do desempenho.

Para Corrêa (2012), as organizações precisam definir quais atividades devem ocorrer para que o pacote de valor oferecido ao cliente atenda ou supere suas expectativas e devem em 
algum momento decidir estrategicamente qual ou quais dessas atividades irão executar com recursos próprios e qual ou quais irão terceirizar, culminando na clássica decisão de comprar ou fazer. Nestas decisões de "comprar ou fazer" é sempre importante o entendimento claro das fontes de criação e alteração lógica de apropriação do valor criado para que as decisões obedeçam sempre a uma lógica objetiva.

\subsubsection{Gestão por processos}

Diante dos desafios e das incertezas decorrentes das mudanças organizacionais, a identificação, o gerenciamento e a medição dos processos oferecem às empresas as ferramentas necessárias para a transformação e a compreensão completa do processo, auxiliando, com isso, a tomada de decisões. A análise do fluxo de trabalho para fins de compreensão e redesenho completo pode apresentar benefício imediato através do uso de padronização de regras e partes dos fluxos e atividades (GOMES, 2020). Meneses (2006) afirma que a formalização dos processos ocorre através de documentação e da imposição dos métodos de trabalhos estabelecidos pela organização para a realização das tarefas.

Gulledge e Rainer (2002) afirmam que o gerenciamento de processos de negócios é uma disciplina antiga na engenharia industrial, valorizada por anos com as implementações localizadas nos processos de manufatura, de envio, entre outros. O gerenciamento de processos estava firmemente estabelecido no chão de fábrica, mas era mais difícil de se estabelecer como uma estratégia de gerenciamento empresarial, principalmente porque era extremamente difícil controlar grandes sistemas de processos integrados.

Segundo Bezerra et al. (2018), apesar de a gestão por processos representar um instrumento de melhoria de desempenho das instituições de negócios, muitas empresas ainda não se encontram orientadas para os processos. A abordagem BPM envolve um ciclo de feedback sem fim para assegurar que os processos de negócio estejam alinhados com a estratégia organizacional e com o foco do cliente.

A melhoria e a sistematização dos processos devem ser precedidas pela identificação dos macroprocessos que exercem grande influência sobre os objetivos estratégicos da organização, definindo-se primeiro as fronteiras existentes entre eles por meio da identificação dos fornecedores e das entradas dos processos, de aquilo que se realiza no processo, da saída do processo (o produto final) e do cliente (interno ou externo) do processo (MENESES, 2006). 
Branco (2016) afirma que processos representam o que uma organização faz, sendo definidos como transformações interfuncionais voltadas a entregar valor aos clientes. Deste modo, o propósito da arquitetura de processos é fornecer uma representação hierárquica de alto nível que integra os processos da empresa. A arquitetura provê um mecanismo coordenado para transformações e melhorias, pois é um meio para o entendimento de como a organização funciona. A arquitetura de processos das organizações trata-se de uma visão organizada dos processos de negócio e das suas relações e diretrizes, através da especificação da estrutura, do comportamento e das informações logísticas, incluindo, respectivamente, a hierarquia das unidades organizacionais e dos papéis do negócio; a hierarquia dos processos de negócio, incluindo inputs e outputs, métricas e níveis de serviços; e objetos de informações do negócio e fluxos de informação.

Tendo em vista o objetivo de formalizar os diversos fatores que impactam na execução do trabalho, diferentes técnicas de caracterização e mapeamento de processos podem ser utilizadas para o alcance de tal padronização, dentre as quais o SIPOC (Supplier, Input, Process, Output e Customer) (GOMES, 2020). O SIPOC é uma ferramenta que ajuda a identificar os elementos relevantes de um processo, obtendo um maior conhecimento sobre determinada atividade e possibilitando identificar oportunidades de melhoria (FARIA, 2017).

ABPMP Brasil (2013) considera o SIPOC uma abordagem especializada para a modelagem de processos, definindo-o como um estilo de documentação de processo usado em Lean Six Sigma para enfatizar as fontes de entradas (suppliers) e o alvo das saídas (customer), que pode ser usado em iniciativas de modelagem ou de melhoria de processos por proporcionar uma análise de perspectiva organizacional.

A ferramenta SIPOC é utilizada para orientar as ações de melhoria tendo em vista os respectivos componentes: - S (Suppliers): fornecedores de insumos (entradas), necessários para que o processo possa ser realizado; - I (Inputs): principais entradas (insumos) fornecidas; - P (Process): descrição sucinta das principais atividades que compõem o processo em análise; O (Outputs): principais saídas (resultados) obtidas após a execução do processo; - C (Customer): os clientes (usuários dos produtos ou serviços) dos resultados gerados (FARIA, 2017).

Conforme ABPMP Brasil (2013), essa técnica pode ser aplicada por meio do preenchimento de uma tabela com os elementos que compõem a sigla, sendo aplicada com mais 
frequência em situações em que é necessário obter um consenso sobre quais aspectos de um processo devem ser estudados. As suas principais características são o arranjo simplificado em forma de tabela e a utilização de textos ou elementos de notação bem entendidos usados para preencher as colunas da tabela, tendo como vantagem a rapidez, a simplicidade e requerer somente um modelo em uma planilha ou um documento em um processador de texto. A Figura 8 demonstra um exemplo de tabela SIPOC preenchida.

\begin{tabular}{|c|c|c|c|c|}
\hline Supplier & Input & Process & Output & Customer \\
\hline $\begin{array}{l}\text { Setor de coleta } \\
\text { Setor de triagem }\end{array}$ & $\begin{array}{l}\text { Material coletado } \\
\text { na rua e doações } \\
\text { Mão de obra }\end{array}$ & Triagem & $\begin{array}{l}\text { Material } \\
\text { separado }\end{array}$ & $\begin{array}{l}\text { Setor de } \\
\text { pesagem }\end{array}$ \\
\hline $\begin{array}{l}\text { Setor de triagem } \\
\text { Setor de } \\
\text { pesagem }\end{array}$ & $\begin{array}{l}\text { Material separado } \\
\text { Mão de obra } \\
\text { Balança }\end{array}$ & Pesagem & Material pesado & $\begin{array}{l}\text { Setor de } \\
\text { prensagem e } \\
\text { enfardamento }\end{array}$ \\
\hline $\begin{array}{l}\text { Setor de } \\
\text { pesagem } \\
\text { Setor de } \\
\text { prensagem }\end{array}$ & $\begin{array}{l}\text { Material pesado } \\
\text { Mão de obra } \\
\text { Prensa }\end{array}$ & $\begin{array}{l}\text { Prensamento e } \\
\text { enfardamento }\end{array}$ & $\begin{array}{l}\text { Material } \\
\text { enfardado }\end{array}$ & $\begin{array}{l}\text { Setor de } \\
\text { expedição }\end{array}$ \\
\hline $\begin{array}{l}\text { Setor de } \\
\text { prensagem e } \\
\text { enfardamento } \\
\text { Setor de } \\
\text { expedição }\end{array}$ & $\begin{array}{l}\text { Material } \\
\text { enfardado } \\
\text { Mão de obra } \\
\text { Caminhão }\end{array}$ & Expedição & $\begin{array}{l}\text { Material } \\
\text { enfardado no } \\
\text { caminhão }\end{array}$ & Cliente final \\
\hline
\end{tabular}

Figura 8: Exemplo de SIPOC preenchido

Fonte: ABPMP Brasil (2013, p. 96)

Segundo Müller (2014), como consequência do entendimento do ambiente que circunda a organização, é necessária a criação de uma arquitetura geral de processos ou dos macroprocessos de funcionamento da organização, através da identificação de todos os macroprocessos da empresa (primários, de apoio e de gestão), sendo que os macroprocessos podem ser desdobrados em Processos, Subprocessos e Atividades. A hierarquia de processos serve para a identificação dos processos essenciais e para análise sistêmica das empresas com o uso de uma estrutura visual que permite que todos os processos sejam tratados de forma padronizada e sistêmica, facilitando a compreensão e as análises críticas executadas pelas equipes de gestão; é uma técnica que descreve verticalmente os fluxos hierárquicos, apresentando cada etapa dos processos, utilizando organogramas para sua representação.

O BPM tornou-se uma área de maior prioridade para a maioria das organizações. Vários estudos foram realizados para identificar os fatores responsáveis pelo sucesso nessa empreitada. 
Bandara et al. (2009) apresentaram um framework holístico com nove fatores de sucesso, a saber, cultura, liderança, comunicação, Tecnologia da Informação, alinhamento estratégico, pessoas, gestão de projetos, medição de desempenho e metodologia, sendo útil para as partes interessadas do projeto BPM no planejamento adequado da iniciativa e na verificação do progresso durante a implementação.

Brocke e Schmiedel (2011) afirmam que o BPM é uma abordagem de gestão que requer uma perspectiva organizacional holística, especialmente porque a cultura é frequentemente considerada um elemento-chave na prática de BPM e a prática gerencial precisa identificar as dimensões de conflitos com base no aspecto cultural. A cultura é referida como uma fonte de falha ou sucesso em iniciativas de BPM, sendo cada vez mais reconhecida como um fator central que influencia e é influenciado pelo BPM. Sendo assim, as abordagens técnicas de BPM que se concentravam no suporte de processos de negócios e em seu design por meio de sistemas de informação estão adotando abordagens holísticas que incluem também outros aspectos organizacionais ao perceber os processos como o núcleo central a partir do qual o negócio é conduzido, visto que eles são apoiados pelas pessoas dentro da organização.

A pesquisa de Saravia-Vergara et al. (2020), conduzida com 187 participantes executivos de empresas peruanas, descobriu que a cultura organizacional é um antecedente que influencia positivamente o sucesso de uma implementação correta de BPM e tem uma relação direta e indireta com os resultados e maturidade do processo. Stemberger et al. (2018) investigaram as diferenças no sucesso das iniciativas de gerenciamento de processos de negócios e a sua conexão com a cultura organizacional através de um questionário que coletou dados sobre as práticas de adoção de BPM em organizações na Áustria, Croácia e Eslovênia com mais de 50 funcionários, a fim de identificar os fatores que discriminam as iniciativas de BPM bem-sucedidas das malsucedidas. O estudo revelou que a chance de sucesso parece ser maior quando a iniciativa de BPM é implementada em toda a organização; quando o BPM é executado em uma base contínua na cultura de hierarquia da organização; quando a abordagem de cima para baixo é usada e quando a iniciativa de BPM tem um papel estratégico e de responsabilidades formais bem definidas.

\subsubsection{Workflow}

A gestão das organizações pode ser, em tese, organizada de forma manual; mas, no contexto das tecnologias de informação (mais conhecidas como sistemas de TI), aplicações para 
uso em ocasiões específicas foram desenvolvidas com a intenção de melhorar o gerenciamento dos negócios. A aplicação prática da automação de processos de negócio, nos quais os documentos, informações e tarefas passam de um colaborador para outro colaborador de acordo com uma determinada hierarquia e seguindo um conjunto pré-estabelecido de regras.

Para Ellis (1999), os problemas que assolam as organizações devido à competitividade global em muitas áreas geram a necessidade contínua de melhorar a produtividade. Muitas organizações obtêm ajuda empregando uma vasta gama de tecnologia de computação para atender às suas necessidades de processamento de informações, sendo o workflow (fluxo de trabalho), um dos tipos mais recentes e populares de ferramenta de grupo/organizacional.

As atividades dentro das organizações podem ser guiadas por meio de uma representação lógica do workflow, termo que, traduzido para o português, significa, literalmente, fluxo de trabalho. Segundo Weske (2012), workflow é a automação de um processo de negócios, dentre o qual documentos, informações ou tarefas são passados de um participante para outro para atuação, de acordo com um conjunto de regras de procedimento. Esta tecnologia é capaz de suportar processos de negócios dentro de um determinado sistema ou entre um conjunto de sistemas de aplicação, integrando eficazmente esses sistemas, bem como pode ser usada para ordenar processos de negócios nos quais os seres humanos estão ativamente envolvidos, melhorando assim a colaboração do conhecimento entre os trabalhadores.

O sistema contém dois componentes básicos: o primeiro é o componente de modelagem de fluxo de trabalho, que permite aos administradores e analistas definirem processos (ou procedimentos) e atividades, analisarem e simularem, e então, atribuí-los às pessoas. O segundo é o componente de execução (ou "encenação") do fluxo de trabalho, que consiste na interface de execução vista pelos usuários finais e no ambiente de execução que auxilia na coordenação e execução dos processos e atividades e que permite que as unidades de trabalho fluam da estação de trabalho de um usuário para outra conforme as etapas de um procedimento são concluídas (ELLIS, 1999).

De maneira geral, a tecnologia workflow não somente garante a comunicação e troca de informações entre diferentes departamentos envolvidos em um mesmo processo de negócio, mas também garante que toda e qualquer tarefa seja executada pelo colaborador para o qual ela foi destinada. Para Ouyang et al (2010), o workflow representa explicitamente as dependências 
do fluxo de controle entre as várias tarefas do processo de negócios, as informações que são necessárias e que podem ser produzidas por eles e a ligação entre essas tarefas e os recursos (sejam eles humanos ou não) que podem executá-los. Desta forma, os processos podem ser executados de forma mais eficiente e eficaz, a conformidade com os procedimentos e práticas padrão pode ser monitorada mais de perto e mudanças rápidas em resposta às condições de mercado em evolução podem ser alcançadas mais facilmente.

A vantagem na sua adoção está no fato de que as atividades da empresa são sistematicamente planejadas e controladas, e a comunicação entre os diversos departamentos da organização se torna mais eficiente, de forma que o fluxo de trabalho da empresa está sendo continuamente otimizado, eliminando-se os gargalos do processo (WESKE, 2012). O fluxo de trabalho registra os eventos que pertencem ao processo, e estes podem ser usados para demonstrar que um processo está em conformidade com as melhores práticas ou com a legislação existente. Além do potencial para economia em termos de tempo e dinheiro, a alteração nos fluxos de trabalho decorrentes das mudanças em seu ambiente é mais fácil, sendo os processos automatizados mais responsivos às alterações e correções.

\subsubsection{BPM na Administração Pública}

As organizações públicas vêm encontrando dificuldades derivadas das restrições financeiras impostas pelos exíguos recursos orçamentários, o que torna necessária a adoção de práticas gerenciais inovadoras como meio de alcançar a otimização de seu desempenho. Cada vez mais, práticas adotadas por organizações públicas estão sendo implantadas em organizações de direito público (GOMES, 2020).

O gerenciamento de processos de negócios tem recebido muita atenção em ambas as literaturas - na gerencial e na de engenharia industrial - com os seus benefícios sendo bem conhecidos. Gulledge e Rainer (2002) afirmam que o que foi escrito na literatura de gestão do setor público é bem menor, porém abrangente e, de forma geral, há muita confusão entre os gestores públicos sobre como os conceitos de gerenciamento de processos de negócios devem ser implementados. Koch (2016) afirma que as referências acerca da aplicação do BPM em organizações públicas ainda são incipientes.

No setor público, o principal benefício da gestão de processos de negócios é o aumento da eficácia e eficiência alcançado com a reestruturação da organização ao longo de processos 
multifuncionais. O primeiro motivo para esta reestruturação diz respeito ao direito público que, por meio da edição de leis, exige a adoção de abordagens de gestão de processos em organizações públicas. O segundo motivo diz respeito à interação entre os processos organizacionais e as novas tecnologias de informação que, ao utilizar sistemas integrados de informação alinhados com os processos de negócios, permitem os processos que agregam valor à organização como um todo (GULLEDGE; RAINER 2002).

Ribeiro et al. (2015) analisaram as aplicações do uso do BPM nos mais diversos ambientes organizacionais, inclusive nas organizações públicas, verificando as práticas de BPM adotadas neste setor a fim de identificar as suas características e as dificuldades encontradas na sua implementação. Os autores chegaram à conclusão de que o BPM é aplicável ao setor público, no entanto, é preciso levar em consideração as especificidades da gestão de processo neste setor, a saber: (i) a existência de processos mais complexos, (ii) as estruturas mais rígidas, (iii) recursos escassos, (iv) além das mudanças ocorridas devido aos regulamentos e leis.

Os problemas mais difíceis no gerenciamento de processos de negócios envolvem o gerenciamento através dos limites funcionais, devido à necessidade de verificar as dinâmicas dos eventos que chegam nos setores e que irão disparar as funções que darão início a um processo. Nas organizações públicas, as fronteiras entre os departamentos são bem definidas, o que dificulta a interação entre processos de departamentos diferentes, sendo necessário que estas organizações mudem as suas estruturas organizacionais radicalmente, bem como seus sistemas empresariais, a fim de implementar conceitos de gerenciamento de processos de negócios com sucesso (GULLEDGE; RAINER, 2002).

O trabalho de Koch (2016) verificou o grau de uso do BPM nas Instituições Federais de Ensino Superior (IFES), tanto em universidades quanto em institutos federais que trabalham com o BPM e que não trabalham com o BPM, identificando que as universidades estão mais avançadas do que os institutos em relação ao trabalho com o BPM, assim como a maioria das IFES que não trabalham com BPM são institutos federais. A conclusão foi de que a cultura do BPM carece de orientação e mais disseminação, bem como a maioria das universidades federais usam ambos no máximo há dois anos.

Gomes (2020), no estudo conduzido em uma Instituição Federal de Ensino Superior, buscou identificar e implantar dois modelos de gestão conjunta (os modelos de gestão do conhecimento e de gestão de processos BPM) por meio do desenvolvimento de uma proposta 
que contemplava o mapeamento e a análise do modelo do processo como forma de integrar os dois modelos, resultando em um método que oferece como resultado de sua aplicação um mapa do processo, como um modelo genérico, e um repositório de conhecimento que oportuniza a documentação e divulgação dos conhecimentos relacionados aos processos estudados.

No plano prático, Corrêa (2020) propôs uma sistemática para a construção de processos, tendo como ponto de partida normas externas e como enfoque as práticas do Gerenciamento de Processos de Negócio (BPM) na Administração Pública, a partir da análise e dos ajustes decorrentes da sua aplicação em um processo de gestão em uma área de serviços terceirizados de uma Instituição Pública de Ensino que, devido à natureza de certas ocorrências (tanto de natureza interna quanto de natureza externa), interferem na estrutura dos processos, criando a necessidade de adaptá-los ou substituí-los rapidamente e de forma ordeira.

O estudo conduzido por Silva (2019) no setor de compras de uma IFE utilizou a gestão por processos como metodologia para orientar a Administração nas atividades desenvolvidas nos processos organizacionais, possibilitando, assim, a identificação dos obstáculos que prejudicam a agilidade, a eficiência e o melhor desempenho dos processos, destacando a escassez de recursos humanos, físicos e orçamentários de forma a permitir a sugestão de propostas de melhorias no âmbito geral da organização.

Sá et al. (2011) demonstraram a utilização da metodologia BPM em uma Instituição Pública de Ensino Superior como meio de gerir o sistema de Gestão Integrada, de maneira que permita a retenção do conhecimento dentro da instituição através do levantamento das informações em todos os níveis hierárquicos da organização e do mapeamento e padronização dos fluxos dentro da organização, permitindo a absorção da maior parte possível da informação.

Oliveira (2018) analisou e identificou quais são os fatores que exercem maior impacto nas etapas de implantação do BPM em Instituições Federais de Ensino Superior, visando identificar quais são os chamados Fatores Críticos de Sucesso (FCS) identificando a existência de cinco dimensões e 21 Fatores Críticos da implantação do BPM em IFES sendo os considerados com maior incidência e de alto impacto os seguintes: (i) Estrutura Organizacional Complexa, (ii) Métricas de Desempenho de Processos, (iii) Disponibilidade de Dados e Informações, (iv) Comprometimento dos Envolvidos no Projeto, (v) Cultura Organizacional Receptiva a Mudanças e (vi) Alinhamento Estratégico. Por meio da identificação das etapas de implantação e de seus Fatores Críticos de Sucesso, uma matriz que relacionou esses elementos 
foi desenvolvida, de modo a permitir a identificação do grau de impacto dos FCS em cada uma das etapas de implantação do BPM, permitindo a criação de um ranking destes FCS.

Silva (2014) analisou os pontos críticos alertados pela bibliografia que causam obstruções (como a (i) mudança organizacional e (ii) o tempo de permanência das lideranças nas funções provocadas por ingerência política, (iii) equipes de trabalho não integradas, (iv) baixa maturidade da organização sobre BPM e (v) a existência de fatores que reduzem o envolvimento e interatividade entre os envolvidos nos processos e em toda a organização) e os que facilitam a implantação do BPM, verificando as incidências nos casos estudados e as variantes destes pontos, vislumbrando a pertinência da sua aplicação em três organizações públicas e mistas que contrataram projetos de mapeamentos de processos. O conjunto de comparações ajudou a identificar e evitar a incidência destes obstrutores conforme as peculiaridades das organizações públicas e mistas, melhorando a introdução da gestão de BPM nas organizações públicas no Brasil.

\subsection{AplicaÇão dos Temas nos Processos de Compras Públicas}

Este capítulo abordará a aplicação na prática dos seguintes temas no âmbito da Administração Pública, especificamente em processos de compras públicas: avaliação de desempenho e aplicação do BMP.

\subsubsection{Avaliação de Desempenho aplicada em processos de Compras Públicas}

O trabalho de Nishiyama (2017) construiu um modelo de avaliação de desempenho para o processo de compras e suprimentos de uma organização de ensino público federal. Por ser uma ferramenta de gestão capaz de auxiliar na melhoria do serviço público, foram identificados critérios de avaliação para a gestão do processo do objeto de estudo. Com a definição de indicadores de desempenho foi possível proceder com uma avaliação que permitiu a mensuração da situação atual do processo de compras e suprimentos e, com isto, permitiu a elaboração de recomendações de melhoria no processo estudado.

Considerando a importância fundamental que a área de compras tem para as organizações e o seu papel estratégico, Pugliese (2019) analisou a área de licitações do Instituto Federal de Educação, Ciência e Tecnologia do Rio de Janeiro (IFRJ) e propôs um método de 
mensuração de desempenho que possibilite a medição do desenvolvimento das atividades dos processos e que proporcione a melhoria contínua nos processos executados no setor estudado. Os resultados obtidos a partir da análise de dados coletados confirmaram o pressuposto da carência de um sistema de medição para a área de licitações e, com o método proposto, foi possível proporcionar à área de licitações e à área de gestão do IFRJ um instrumento para monitorar e controlar as compras e contratações e melhorar o desempenho do Setor de Licitações de modo planejado e contínuo, mostrando a viabilidade da adoção, na Administração Pública, de ferramentas de monitoramento e controle para a área de licitações.

Mendes (2016) propôs indicadores de desempenho com base na Cadeia de Valor e nos 6Es do Desempenho (compostos por seis dimensões de avaliação: efetividade, eficácia, eficiência, execução, excelência e economicidade) para os processos de compras do Instituto Federal de Mato Grosso do Sul, Campus Dourados. Como resultado, após a análise dos dados obtidos nos anos de 2017 e 2018, os seguintes indicadores foram propostos: "satisfação final do usuário", "contratos com advertências", "contratos com aditivos", "contratos com multas", "contratos cancelados", "tempo estimado desde a abertura do processo de pregão eletrônico até a publicação do edital", "tempo de tramitação entre a publicação do edital do pregão eletrônico e a homologação do resultado", "licitações desertas", "licitações impugnadas", "contratos com micro e pequenas empresas", "compras sustentáveis" e "diferença entre o preço de referência e o preço homologado".

Faria (2012) analisou o cenário das compras públicas realizadas pela Coordenação de Qualificação de Material da Secretaria de Estado de Saúde do Rio de Janeiro, um setor que assessora o setor de compras. A pesquisa teve como objetivo aplicar a metodologia de gestão por processos no mapeamento das compras de material médico-hospitalar de consumo, visando a melhoria das atividades das etapas do processo através do mapeamento dos processos de normalização (padronização/seleção de insumos médicos) e de aquisição de materiais de consumo (descartáveis), de forma a permitir a construção de protocolos organizacionais fundamentados na gestão por processos que sirvam para subsidiar a normalização e a aquisição de materiais médico-hospitalares de consumo, e da sua avaliação através de indicadores. Através do mapeamento do processo foi possível traçar uma proposta gerencial com inovação organizacional por meio da elaboração de um sistema de indicadores para gerenciar e monitorar os processos de normalização e de aquisição. 
Brito et al. (2016) descrevem a experiência da implantação de indicadores na área de compras públicas de um hospital público federal como um instrumento de avaliação de desempenho organizacional que objetiva mensurar a evolução da organização frente as metas definidas. Os resultados obtidos identificaram oportunidades que demonstram a imperatividade da utilização dos indicadores como forma de prover um processo de compra pública eficiente.

Ramos (2012), em um estudo conduzido em um Setor de Compras pertencente a uma empresa de transporte metroviário de Porto Alegre que se utiliza de recursos financeiros públicos, identificou um cenário recente de resultados de licitações cancelados, anulados e revogados, o que pode indicar um baixo nível de eficiência dos seus processos licitatórios. Por meio da observação da aderência dos processos licitatórios às práticas de gerenciamento de projetos, propôs-se realizar a avaliação do sistema de gestão de licitações da empresa por meio do estudo dos processos que compreendem a fase de preparação (planejamento) das licitações, de maneira a permitir a comparação com padrões e metas e a avaliação da eficiência da condução do processo de compras.

\subsubsection{BPM aplicado aos processos de Compras Públicas}

Reis (2017) afirma que o processo de compras desempenha um papel fundamental nos órgãos governamentais e que o setor de licitação, responsável pelas aquisições de bens e serviços, precisa melhorar a questão da qualidade e da produtividade do serviço prestado. A proposta para melhoria do processo de compras ocorreu por meio do mapeamento do processo de compras; da identificação e da priorização dos problemas; da identificação das causas fundamentais destes problemas; da elaboração de um plano de ação para bloquear as causas fundamentais e, por fim, da proposição de sugestões de melhoria para o processo.

Trindade (2016) utilizou o mapeamento de processos para identificar e analisar as atividades que supostamente são causadoras de ineficiência nos processos de compras públicas eletrônicas em uma Universidade Federal. Com a identificação das causas das prováveis morosidades processuais, causadoras da ineficiência e da ineficácia das compras do órgão, foi possível identificar fluxos de informação desnecessários e duplicidades contextuais e administrativas, responsáveis pela morosidade dos processos, permitindo o desenvolvimento de rotinas capazes de melhorar os procedimentos e agregar qualidade aos produtos e serviços adquiridos. 
Trilha et al. (2018) analisaram os processos de compra de materiais de consumo de uma Instituição Federal de Educação Superior - IFES através da descrição das atividades desempenhadas durante o processo de compra direta. O uso do mapeamento do processo, utilizando as metodologias BPMN e BPMS, possibilitou a visualização do processo como um todo, a identificação das inconsistências, o apontamento de melhorias na utilização dos recursos, bem como a identificação de todos os envolvidos no processo e a interação entre eles.

A gestão dos processos de compras em universidades públicas no estado de Santa Catarina foi estudada por Alves e Nunes (2017). A partir dos dados coletados e por meio de levantamento documental nas próprias instituições estudadas e de sua análise foi possível comparar os diversos aspectos relacionados à gestão dos processos de compras das instituições estudadas e à avaliação da gestão destes processos e, também, apontar os pontos fortes e pontos fracos de tal gestão. As diferentes características dos processos de compras das instituições estudadas e os aspectos que precisam ser aperfeiçoados para alcançarem um nível de eficiência adequado foram identificados.

O trabalho de Silva (2018) recaiu sobre os processos de compras públicas de maneira a propor melhorias nos processos de gestão de compras de um Instituto Federal de Ciência e Tecnologia, a partir da análise da percepção de dois grupos de servidores (os com função de gestor e os não gestores). A comparação das perspectivas identificou a existência de um longo caminho a percorrer para que se atinja um nível de eficiência, eficácia e efetividade adequado nos processos de compras, sendo que as ferramentas e técnicas da gestão de processos podem auxiliar neste caminho.

Borges et al. (2016) utilizaram o mapeamento de processos para identificar possíveis melhorias no processo de compra de bens na modalidade pregão presencial com registro de preço do Tribunal Regional Eleitoral do Estado da Paraíba (TRE-PB). Verificaram que o processo é marcado por entraves burocráticos que dificultam o fluxo devido à excessiva e desnecessária concentração de atividades em determinadas coordenadorias e secretarias superiores, resultando em um tempo elevado de duração de todo o fluxo, o que poderia ser evitado caso a organização adotasse sugestões de melhorias propostas no trabalho.

O Quadro 5 apresenta a compilação com as aplicações dos temas estudados no âmbito dos públicos de compras e aquisições. 


\begin{tabular}{|c|c|c|}
\hline Autor & Instituição & Aplicações \\
\hline \multicolumn{3}{|r|}{ Tema: Avaliação de Desempenho } \\
\hline $\begin{array}{l}\text { Nishiyama } \\
(2017)\end{array}$ & $\begin{array}{l}\text { Ensino Público } \\
\text { Federal }\end{array}$ & $\begin{array}{l}\text { Uso de indicador de desempenho para a mensuração da situação } \\
\text { atual do processo de compras e suprimentos e elaboração de } \\
\text { recomendações de melhoria no processo estudado. }\end{array}$ \\
\hline $\begin{array}{l}\text { Pugliese } \\
(2019)\end{array}$ & $\begin{array}{l}\text { Instituto Federal de } \\
\text { Educação IFRJ }\end{array}$ & $\begin{array}{l}\text { Proposição de um método de mensuração de desempenho para } \\
\text { medir o desenvolvimento das atividades dos processos e } \\
\text { proporcionar a melhoria contínua. }\end{array}$ \\
\hline $\begin{array}{l}\text { Mendes } \\
(2016)\end{array}$ & $\begin{array}{l}\text { Instituto Federal de } \\
\text { Mato Grosso do Sul }\end{array}$ & $\begin{array}{l}\text { Proposição de indicadores de desempenho com base na Cadeia de } \\
\text { Valor e nos 6Es do Desempenho para os processos de compras. }\end{array}$ \\
\hline Faria (2012) & $\begin{array}{l}\text { Secretaria de } \\
\text { Estado de Saúde do } \\
\text { Rio de Janeiro }\end{array}$ & $\begin{array}{l}\text { Aplicação da metodologia de gestão por processos e mapeamento } \\
\text { das compras de material médico-hospitalar de consumo e } \\
\text { elaboração de um sistema de indicadores para gerenciar e } \\
\text { monitorar os processos de aquisição. }\end{array}$ \\
\hline $\begin{array}{l}\text { Brito et al. } \\
(2016)\end{array}$ & $\begin{array}{l}\text { Hospital público } \\
\text { federal }\end{array}$ & $\begin{array}{l}\text { Implantação de indicadores na área de compras públicas de um } \\
\text { Hospital Público Federal como Instrumento de avaliação de } \\
\text { desempenho organizacional. }\end{array}$ \\
\hline $\begin{array}{l}\text { Ramos } \\
(2012)\end{array}$ & $\begin{array}{l}\text { Empresa de } \\
\text { transporte } \\
\text { metroviário }\end{array}$ & $\begin{array}{l}\text { Avaliação do sistema de gestão de licitações por meio do estudo } \\
\text { do processo de compras, comparando com padrões e metas e a } \\
\text { avaliação da eficiência da condução do processo de compras. }\end{array}$ \\
\hline \multicolumn{3}{|r|}{ Tema: BPM } \\
\hline Reis (2017) & $\begin{array}{l}\text { Órgão } \\
\text { governamental }\end{array}$ & $\begin{array}{l}\text { Mapeamento do processo de compras: identificação e priorização } \\
\text { dos problemas e das causas fundamentais destes problemas; } \\
\text { elaboração de um plano de ação para bloquear as causas } \\
\text { fundamentais e a proposição de sugestões de melhoria para o } \\
\text { processo. }\end{array}$ \\
\hline $\begin{array}{l}\text { Trindade } \\
(2016)\end{array}$ & $\begin{array}{l}\text { Universidade } \\
\text { Federal }\end{array}$ & $\begin{array}{l}\text { Utilização do mapeamento de processos para identificar e analisar } \\
\text { as atividades supostamente causadoras de ineficiência nos } \\
\text { processos de compras. }\end{array}$ \\
\hline $\begin{array}{l}\text { Trilha et al. } \\
\text { (2018) }\end{array}$ & $\begin{array}{l}\text { Instituto Federal de } \\
\text { Educação Superior }\end{array}$ & $\begin{array}{l}\text { Utilização do BPMN e BPMS, visualizando o processo como um } \\
\text { todo e identificar as inconsistências e apontar melhorias na } \\
\text { utilização dos recursos. }\end{array}$ \\
\hline $\begin{array}{lr}\text { Alves } & \text { e } \\
\text { Nunes }(2017)\end{array}$ & $\begin{array}{l}\text { Universidades } \\
\text { Públicas em Santa } \\
\text { Catarina }\end{array}$ & $\begin{array}{l}\text { Comparação dos diversos aspectos relacionados à gestão dos } \\
\text { processos de compras em Universidades Públicas e avaliação da } \\
\text { gestão destes processos. }\end{array}$ \\
\hline Silva (2018) & $\begin{array}{l}\text { Instituto Federal de } \\
\text { Ciência e } \\
\text { Tecnologia }\end{array}$ & $\begin{array}{l}\text { Proposição de melhorias nos processos de gestão de compras, a } \\
\text { partir da análise da percepção de dois grupos de servidores. }\end{array}$ \\
\hline $\begin{array}{l}\text { Borges et al. } \\
\text { (2016) }\end{array}$ & $\begin{array}{l}\text { TRE do Estado da } \\
\text { Paraíba }\end{array}$ & $\begin{array}{l}\text { Utilização do mapeamento de processos para identificar possíveis } \\
\text { melhorias no processo de compra de bens }\end{array}$ \\
\hline
\end{tabular}

Quadro 5: Resumo das principais aplicações dos temas nos processos de Compras Públicas

Fonte: Elaborado pelo autor 


\subsubsection{Considerações sobre a revisão da literatura}

A transparência e a prestação de contas, conforme Hoffman (2017), têm sido temáticas extremamente atuais no que concerne à Administração Pública. Cada vez mais os gestores públicos precisam fazer mais com menos recursos financeiros disponíveis. A cobrança por parte da sociedade civil força o surgimento, no serviço público, de uma cultura voltada para o alcance de resultados com maior foco na eficiência e nos resultados, proporcionando as condições necessárias para a adoção, pela Administração Pública, de instrumentos de mensuração de resultados, um importante instrumento de gestão já largamente utilizado na administração privada.

Para Lemos (2021), os indicadores de desempenho são aliados do processo de gestão na busca pelo alcance dos resultados organizacionais almejados. $\mathrm{O}$ autor vislumbra uma utilidade estratégica e gerencial para os indicadores, por servirem como base de apoio às escolhas na gestão pública, tornando-as mais assertivas. Para isso, no decorrer deste trabalho, foram apresentadas algumas definições sobre indicadores de desempenho, além de avaliações da sua adequação, da sua pertinência de uso e dos desafios existentes para que ocorra o aprimoramento necessário na gestão administrativa pública, revelando a sua utilidade estratégica e gerencial como base de apoio às decisões.

Nesse capítulo, procurou-se abordar os conceitos de processos, gestão de compras e avaliação de desempenho por meio de indicadores de desempenho. Da mesma forma, foram levantadas algumas considerações sobre as organizações públicas, com o intuito de auxiliar no desenvolvimento de uma sistemática de avaliação de desempenho para processos de compras por licitação, de modo a possibilitar a realização de uma análise de aderência e das adaptações necessárias para a adoção da sistemática.

A seguir, serão apresentados os procedimentos metodológicos para, em seguida, ser abordado o desenvolvimento e a aplicação da sistemática em uma Universidade Pública de ensino situada na cidade de Porto Alegre. 


\section{Procedimentos metodológicos}

Neste capítulo, será apresentada a metodologia empregada no presente estudo, ou seja, o conjunto de técnicas utilizadas para a realização da pesquisa. São descritos o objeto do estudo, a classificação da pesquisa e o método de trabalho com as fases a serem adotadas.

\section{1 ОвJЕTо}

A história da educação superior no Rio Grande do Sul tem início com a fundação, na cidade de Porto Alegre, da Escola de Farmácia e Química no ano de 1895 e, logo a seguir, da Escola de Engenharia. Nos anos seguintes também foram criadas as Faculdades de Medicina e de Direito, mas a Universidade de Porto Alegre, como era chamada, só foi fundada em 28 de novembro de 1934. Em 1947, com o propósito de integrar os institutos do interior do estado, a instituição passou a se chamar Universidade do Rio Grande do Sul. No ano de 1950 ocorreu a federalização, passando a adotar o nome de Universidade Federal do Rio Grande do Sul. Atualmente, a instituição possui 90 cursos de graduação presenciais, 5 cursos de graduação à distância, 81 programas de mestrado, 74 programas de doutorado e 168 cursos de pósgraduação lato sensu. Conforme dados disponibilizados em sua página, em 2018, a UFRGS possuía 2.852 docentes de ensino superior e 2.611 técnicos administrativos.

O trabalho foi aplicado na Universidade Federal do Rio Grande do Sul (UFRGS), uma instituição pública federal de ensino, educação e pesquisa, junto ao setor responsável pela execução das tarefas relacionadas à aquisição de bens e serviços. A Universidade do Estado do Rio Grande do Sul, uma entidade pública de educação vinculada ao Ministério da Educação, deve seguir o regramento legal existente - conhecido como licitação pública - para todas as suas aquisições e contratações. Tendo em vista os esforços para se promover uma melhor gestão dos seus processos, através da implementação de melhorias e de práticas de gestão mais eficientes na Administração Pública e de gasto mais racional dos recursos financeiros disponíveis, o controle, acompanhamento e monitoramento dos processos se faz fundamental.

O estudo foi desenvolvido tendo por base o processo de compras na UFRGS. A execução deste processo é de responsabilidade do DELIT - Departamento de Aquisição de Bens e Serviços, setor vinculado à Pró-Reitoria de Planejamento que, após receber as demandas de aquisição por parte das diversas unidades da UFRGS, providencia e executa o procedimento 
licitatório, iniciando com a fase de planejamento (preparação e confecção de documentos), passando pelas autorizações das autoridades competentes e culminando com a execução da licitação (execução da disputa para a definição e escolha do fornecedor). Dentro do organograma da UFRGS, apresentado no Anexo 1, o DELIT está vinculado estruturalmente à PROPLAN (Anexo 2).

O DELIT atua no planejamento, controle e execução das tarefas relativas às aquisições e às licitações da UFRGS, conforme as atribuições apresentadas no Anexo 3. Atualmente, o setor está estruturado em quatro divisões:

1) Divisão de Planejamento e Controle de Aquisições (DPCA): tem como função realizar o gerenciamento do processo de aquisição de bens e serviços e do Plano Anual de Aquisições da UFRGS (PAAQ/UFRGS), bem como coordenar os grupos de trabalho para as licitações globais da Universidade (planejar as compras, agregando as demandas recebidas ou identificadas);

2) Divisão de Preparo da Licitação (DPL): tem por função elaborar a documentação que servirá como divulgação e regramento do procedimento licitatório (elaboram os Editais de Licitação e demais documentos). Setor responsável, também, por cadastrar a licitação no sistema próprio do Governo Federal, onde todas as licitações de órgãos federais são centralizadas e realizadas;

3) Divisão de Execução da Licitação (DIVLIC): tem por função atender as demandas das Unidades no que tange à execução das licitações e compras da UFRGS (operacionalizam e executam a etapa de seleção do fornecedor);

4) Divisão de Importação (DIVIMPORT): o objetivo do setor é executar e auxiliar no procedimento de importações e exportações nas diversas instâncias da Instituição e junto aos órgãos anuentes externos, bem como prestar aos requisitantes toda assessoria necessária durante a aquisição, apoiando os importadores desde a requisição até a entrega do bem importado.

O processo a ser estudado envolve as divisões do DELIT, a saber as divisões DPCA, DPL e DIVLIC. As organizações destas áreas já são aderentes ao processo estudado, pois já estão estruturadas seguindo o processo de compras. 


\title{
3.2 ClassificaÇão da PESQUiSa
}

Considerando o ambiente de pesquisa, a abordagem teórica e as técnicas de coleta e análise de dados, é possível afirmar que a modalidade de pesquisa a ser adotada se classifica como pesquisa-ação. Este procedimento tem como propósito proporcionar a aquisição de conhecimentos claros, precisos e objetivos por apresentar características situacionais, visto que procura diagnosticar um problema específico numa situação específica, com vistas a alcançar algum resultado prático (GIL, 2010).

Segundo Severino (2013, p. 75), a pesquisa-ação é

\begin{abstract}
"aquela que, além de compreender, visa intervir na situação, com vistas a modificála. O conhecimento visado articula-se a uma finalidade intencional de alteração da situação pesquisada. Assim, ao mesmo tempo que realiza um diagnóstico e a análise de uma determinada situação, a pesquisa-ação propõe ao conjunto de sujeitos envolvidos mudanças que levem a um aprimoramento das práticas analisadas. "
\end{abstract}

Diferentemente da pesquisa tradicional, não visa apenas obter enunciados científicos generalizáveis, mas envolve também a ação dos pesquisadores e dos grupos interessados, o que ocorre nos mais diversos momentos da pesquisa com vistas à resolução de um problema coletivo, onde todos pesquisadores e participantes estão envolvidos de modo cooperativo e participativo (GIL, 2010). Conforme Mallmann (2015), a proposição teórico-metodológica da pesquisa-ação é utilizada nos mais diversos campos de atuação com implementação nos últimos 20 anos.

Pesquisa pode ser definida como um procedimento racional e sistemático onde se procura acumular respostas aos problemas definidos através de ações planejadas que desenvolvem todo o processo de pesquisa (GIL, 2010). Com base no objetivo do estudo, é possível estabelecer que a natureza da pesquisa aplicada é do tipo explicativa, pois envolve levantamento bibliográfico e análise documental dos processos internos já mapeados. Tendo em vista que o pesquisador tem participação direta na solução do problema proposto, o delineamento no quesito procedimento técnico foi o de pesquisa-ação realizando grupos de pesquisa e discussão com os servidores envolvidos nos processos licitatórios (GIL, 2010), adotando-se como procedimentos os conceitos do Design Science Research (DSR).

O DSR tem sido considerado um método para a condução de pesquisas de cunho tecnológico, por exemplo, em tecnologias de gestão, constituindo uma abordagem que, quando bem aplicada, produz rigor científico efetivo (LACERDA et al., 2013). É um processo que 
utiliza a teoria como base para a construção de artefatos que são avaliados por meio de técnicas analíticas a fim aperfeiçoar a teoria que será aplicada para resolver um problema de natureza prática (OLIVEIRA, Andressa, 2018).

O DSR é composto por cinco etapas: conscientização (identificação do problema), sugestão (desenvolvimento de alternativas para a solução do problema), desenvolvimento (construção do artefato para solucionar o problema), avaliação (verificação do artefato no contexto para o qual foi desenvolvido) e conclusão (formalização do processo e sua comunicação) (OLIVEIRA, Andressa, 2018).

Este estudo utilizou como método de pesquisa o Design Science Research, uma vez que o mesmo se propõe à produção de um artefato para a resolução de um problema específico, neste caso, a implementação de um sistema de medição para avaliar o desempenho dos processos licitatórios para a aquisição de bens e contratação de serviços das organizações de natureza pública. $\mathrm{O}$ estudo foi desenvolvido com base nas cinco fases, e a síntese das ações planejadas são demonstradas na Figura 9.

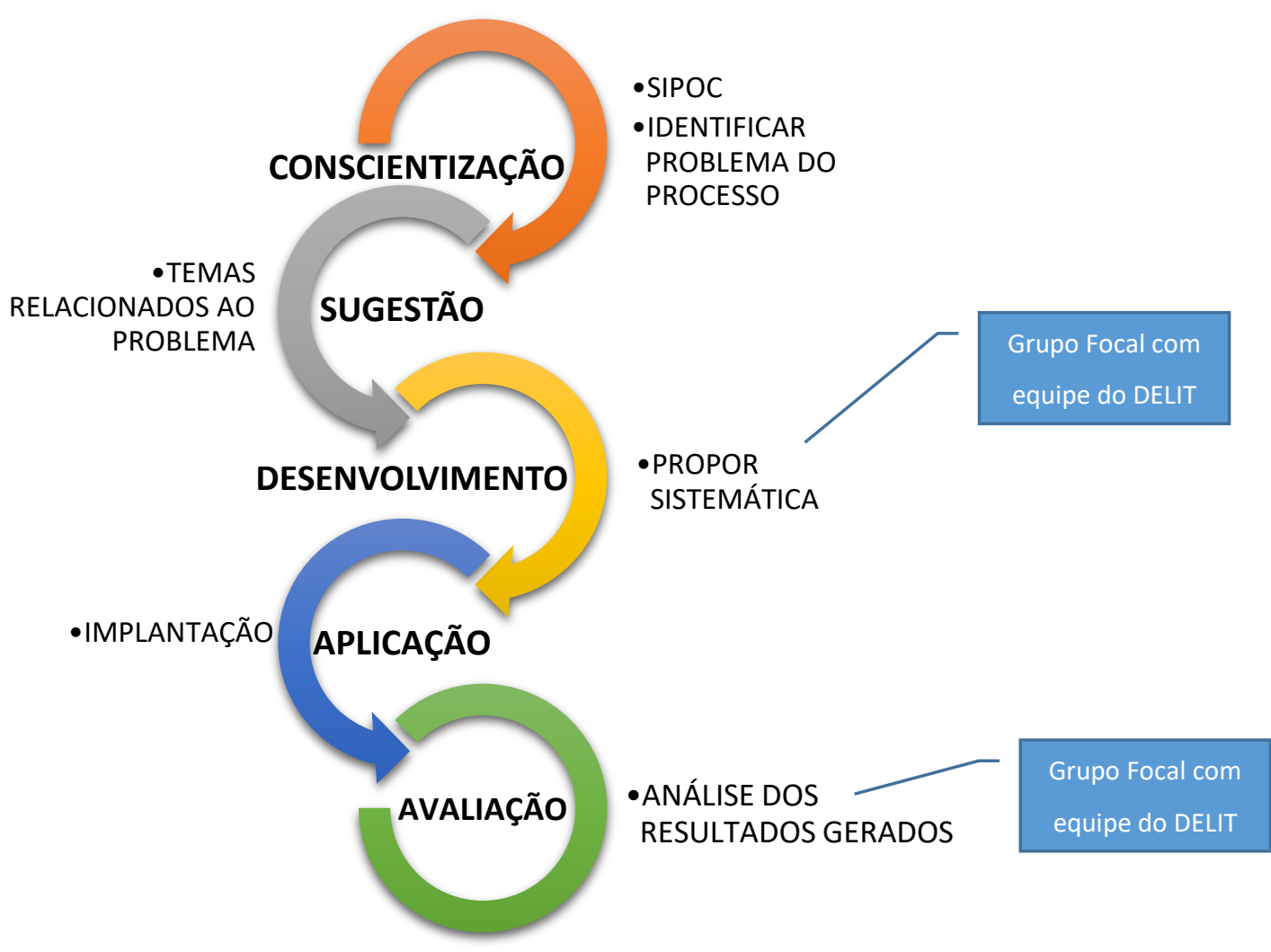

Figura 9: Resumo das ações planejadas para a execução do método do trabalho

Fonte: Adaptado de Gomes (2020, p. 65) 


\subsection{MÉtodo DE TRABALHO}

A condução do presente estudo estará dividida em 5 fases, permitindo um maior detalhamento de todo o processo da pesquisa desenvolvida. A primeira fase envolve a conscientização do problema por meio da caracterização do processo analisado, seguida pela sugestão com o levantamento bibliográfico da produção científica relativo ao tema do estudo. A terceira fase trata do desenvolvimento da sistemática que irá permitir instrumentalizar as ações de melhorias propostas. A quarta e a quinta fases tratarão da aplicação e avaliação dos resultados obtidos e da pertinência de seu uso.

A coleta e a análise dos dados utilizados nesse trabalho foram realizadas mediante a observação participante, análise documental, pesquisa bibliográfica e reuniões realizadas junto aos membros do grupo focal, conforme demonstrado no Quadro 6.

\begin{tabular}{|c|c|c|c|c|}
\hline \multirow[b]{2}{*}{ Fase } & \multicolumn{4}{|c|}{ Método de coleta e análise } \\
\hline & $\begin{array}{l}\text { Observação } \\
\text { Participante }\end{array}$ & $\begin{array}{c}\text { Análise } \\
\text { Documental }\end{array}$ & $\begin{array}{c}\text { Pesquisa } \\
\text { Bibliográfica }\end{array}$ & Reuniões \\
\hline Fase 1: Conscientização do Problema & $\mathrm{X}$ & $\mathrm{X}$ & & \\
\hline Fase 2: Sugestão & & & $\mathrm{X}$ & \\
\hline Fase 3: Desenvolvimento da Sistemática & $\mathrm{X}$ & & $\mathrm{X}$ & $\mathrm{X}$ \\
\hline Fase 4: Aplicação da Sistemática & $\mathrm{X}$ & $\mathrm{X}$ & & $\mathrm{X}$ \\
\hline Fase 5: Avaliação da Sistemática & $\mathrm{X}$ & & & $\mathrm{X}$ \\
\hline
\end{tabular}

Quadro 6: Técnicas de coleta e análise de dados utilizadas no estudo

Fonte: Elaborado pelo autor

A análise de documentos internos já existentes e disponíveis para consulta foram usados para compreender o cenário de estudo e a dinâmica de funcionamento do órgão, permitindo dirimir as dúvidas surgidas ao longo do estudo. Documentos referentes à legislação aplicadas ao processo estudado forma usados, bem como o contexto dos problemas do processo foi abordado e levantado junto com servidores de unidades do órgão que demandam o serviço e recebem o resultado final do processo estudado.

Durante o desenvolvimento da sistemática, nas fases de Desenvolvimento, Aplicação e Avaliação da sistemática foi realizada reuniões com os membros do grupo focal criado com o objetivo de auxiliar na coleta de dados e na análise dos resultados para, então, os dados e resultados serem compilados pelo pesquisador. A dinâmica das reuniões seguiu, em sua 
maioria, os mesmos procedimentos básicos: apresentação dos objetivos da etapa e ações a serem executadas identificados pelo pesquisador, tempo e prazo para coleta dos dados, exposição da opinião dos participantes sobre a etapa realizada e construção de um resultado para validação ao final da fase por todos os membros.

Cada uma das fases será descrita a seguir, sendo o seu resultado descrito de forma mais detalhada no Capítulo 4.

\subsubsection{Fase 1: Conscientização do Problema}

Esta etapa do trabalho caracteriza-se pelo objetivo de formalizar e definir o problema a ser estudado, caracterizando-o de forma a permitir a identificação de uma solução. A descrição do cenário contém as informações necessárias para a construção sistemática.

A conscientização do problema se dá a partir de duas análises. Em um primeiro momento, é realizada uma análise do cenário específico do problema real que se pretende resolver e que foi a motivação do estudo, oportunizando conhecer as peculiaridades do contexto para o qual a sistemática é desenvolvida e aplicada. Em um segundo momento, a conscientização do problema se dá a partir da revisão da literatura, de forma a permitir a compreensão da problemática envolvida com os temas relacionados ao problema específico identificado.

A partir da análise do cenário descrito, foi possível identificar as dificuldades encontradas para gerir um processo crítico para a organização e os conhecimentos relacionados àquele cenário específico. Além disso, foi possível definir o problema, a saber: identificar e propor indicadores que possibilitem medir o desempenho para processos licitatórios.

Em um segundo momento, a gestão de processos e a avaliação de desempenho foram consideradas temas que apresentam relações com o estudo e que se apresentam como possíveis soluções, e buscou-se compreender esses temas a partir de uma revisão da literatura, considerando estudos que trataram os temas isoladamente e em conjunto. Foram considerados estudos que pesquisaram a utilização dessas ferramentas de gestão em organizações públicas, visto que a solução buscada seria aplicada em uma Instituição Federal de Ensino. Os principais conceitos são apresentados no Capítulo 2 - Referencial Teórico. 


\subsubsection{Fase 2: Sugestão}

Nesta etapa busca-se alternativas para a construção de uma solução. Para o presente estudo, esta etapa caracteriza-se pela busca de apoio no referencial teórico, baseado no problema do contexto específico, sobre os temas de gestão de processos e avaliação de desempenho, considerando, nos estudos realizados sobre estes dois temas, as aplicações em ambientes reais dos dois temas, bem como procura identificar aplicações em organizações públicas de forma a permitir buscar alternativas que pudessem resolver o problema identificado.

Nessa etapa foram registradas as tentativas de desenvolvimento da sistemática e identificados os indicadores possíveis de uso. Essas tentativas estão descritas com mais detalhes no Capítulo 4.

\subsubsection{Fase 3: Desenvolvimento da Sistemática}

Concluída a etapa de conscientização do problema, onde foi possível compreender e identificar o problema a ser solucionado a partir da análise de seu contexto específico e dos conceitos importantes para o embasamento da construção de uma sistemática capaz de solucioná-lo, e a etapa de sugestão, em que, a partir de um processo criativo, buscou-se alternativas para solucionar o problema, passou-se à etapa de desenvolvimento.

Considerando a literatura estudada e o contexto em que seria aplicada, a alternativa que se vislumbrou adequada foi fazer a proposição de uma sistemática que integrasse aspectos da gestão de processos e da avaliação de desempenho a partir dos resultados das abordagens teóricas encontradas, levando, ainda, em consideração ferramentas que já haviam sido desenvolvidas. Essa etapa se caracteriza pelo processo de constituição da sistemática em si e é descrita de forma mais detalhada no Capítulo 4, que apresenta os resultados do estudo.

As etapas iniciais para a implantação do BPM não são necessárias, pois já havia a definição prévia a respeito de qual processo da UFRGS seria analisado. As etapas para a construção da sistemática serão compostas por:

a) Caracterizar o processo (SIPOC);

b) Mapear minimamente o processo;

c) Definir os indicadores para as etapas mapeadas que compõem o processo; 
d) Identificar e levantar a(s) fonte(s) de dados;

e) Coletar os dados;

f) Divulgar os dados processados;

g) Análise da pertinência dos resultados processados.

\subsubsection{Fase 4: Aplicação da Sistemática}

Nesta etapa busca-se produzir a evidência prática da validação da sistemática criada, a partir da sua implementação. A sistemática foi apresentada em seu estado funcional, demonstrando aplicabilidade na prática, com o uso de dados de processo reais.

Esta etapa contemplou a aplicação da sistemática na UFRGS, cenário que motivou o estudo no setor responsável pela realização do processo. Essa fase é descrita de forma mais detalhada no Capítulo 4, que apresenta os resultados do estudo.

\subsubsection{Fase 5: Avaliação da Sistemática}

Por último, é realizada a avaliação da sistemática desenvolvida a partir dos resultados obtidos na etapa de Aplicação do Artefato, verificando seu comportamento em relação ao ambiente para o qual foi projetado e a sua adequação quanto à geração de resultado de solução ao problema identificado.

A avaliação da sistemática é feita ao longo de todo o período de sua aplicação, a partir das observações feitas pelos membros da equipe sobre o trabalho que está sendo desenvolvido. Ao final, são discutidos com a equipe os pontos positivos e negativos da sistemática, com a consolidação dos resultados obtidos por meio de uma análise crítica. Essa fase é descrita de forma mais detalhada no Capítulo 4. 


\section{Resultados e discussão}

Este capítulo apresenta os resultados encontrados na pesquisa e a análise do ambiente pesquisado. A discussão dos resultados é dividida em quatro aspectos: a descrição do órgão, uma análise do ambiente atual e da forma de condução do processo, a proposição de adoção de uma sistemática de medição e controle da mensuração de desempenho. Conforme descrito anteriormente, este estudo compreende a análise do ambiente real em que está inserido o processo estudado e a busca pela identificação e proposição de uma sistemática de medição e controle de processos que permita, desta forma, um melhor desempenho geral e que culmine na obtenção de resultados satisfatórios para os clientes internos. Dentre as 5 fases do método de trabalho adotadas, a segunda fase (a de Sugestão) está compreendida dentro da Revisão Bibliográfica, sendo que na sequência estão demonstrados os resultados destas fases.

\subsection{ConscientizaÇão do Problema}

A conscientização do problema estudado se deu a partir de dois momentos distintos, conforme descrito no item 3.3.1 do capítulo anterior. Em um primeiro momento, o problema a ser estudado foi identificado, sendo realizada a análise específica do cenário da pesquisa, neste caso, o processo de compras adotado na UFRGS; e em um segundo momento, mediante a compreensão dos temas relacionados àquele problema, ou seja, a gestão de processos e a avaliação de desempenho.

\subsubsection{Descrição do cenário na UFRGS}

A UFRGS vem implantando, desde 2012, a Gestão por Processos através da realização de diferentes iniciativas, podendo-se citar como exemplo a criação do Escritório de Processos, a modelagem e melhoria de processos, a realização de capacitações para promoção da cultura de processos e a construção da arquitetura de processos. Para o entendimento do ambiente que circunda a UFRGS, a arquitetura geral de processos ou dos macroprocessos de funcionamento da Universidade foram identificados e mapeados e estão demonstrados na Figura 10. 


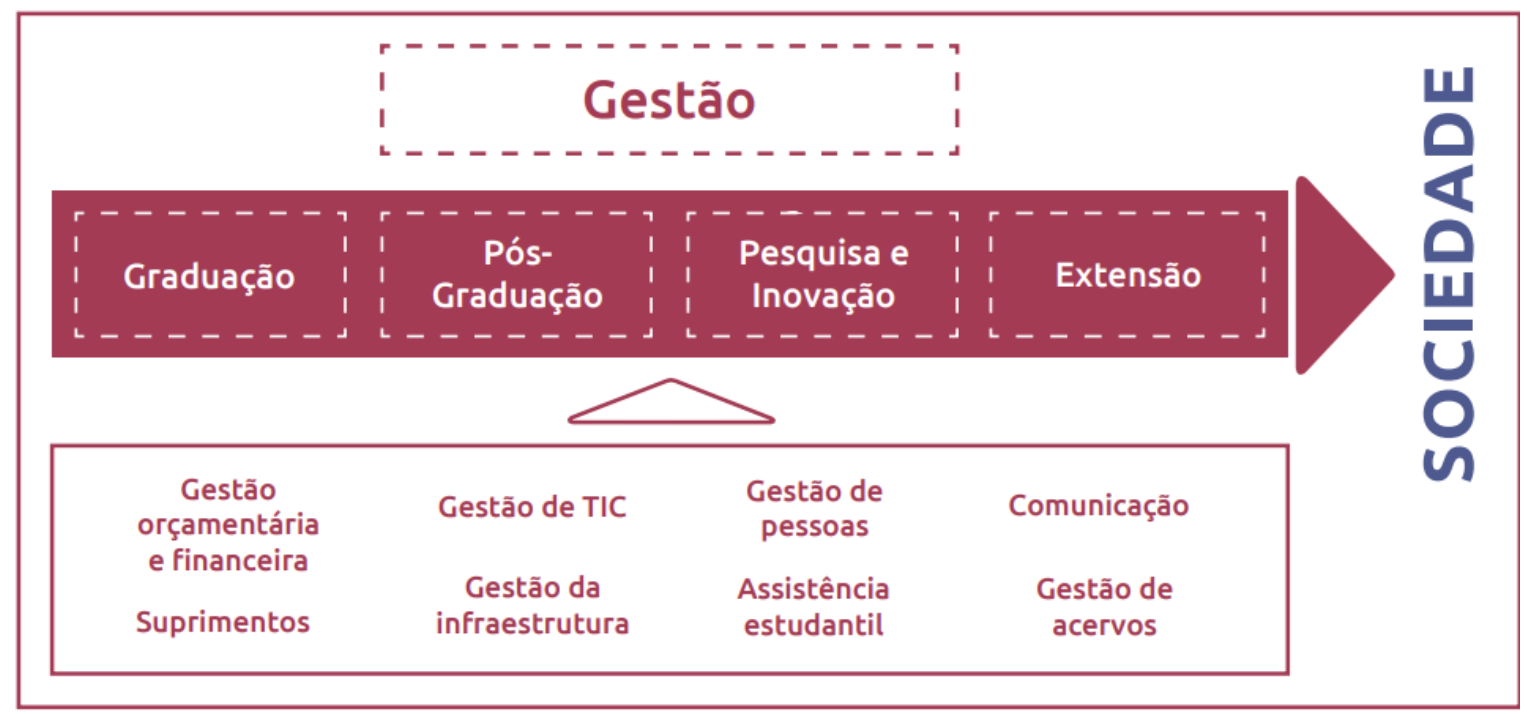

Figura 10: Macroprocessos UFRGS

Fonte: UFRGS (2020, p. 49)

Dentre os macroprocessos identificados, o de Suprimentos é aquele que se refere às atividades relacionadas ao processo de compras e que apresenta como objetivo o atendimento das necessidades de suprimentos no menor tempo, com a maior qualidade e economicidade, conforme pode ser visto no macroprocesso Suprimentos da Figura 11 e na caracterização dos processos (SIPOC) do macroprocesso Suprimentos na Figura 12.

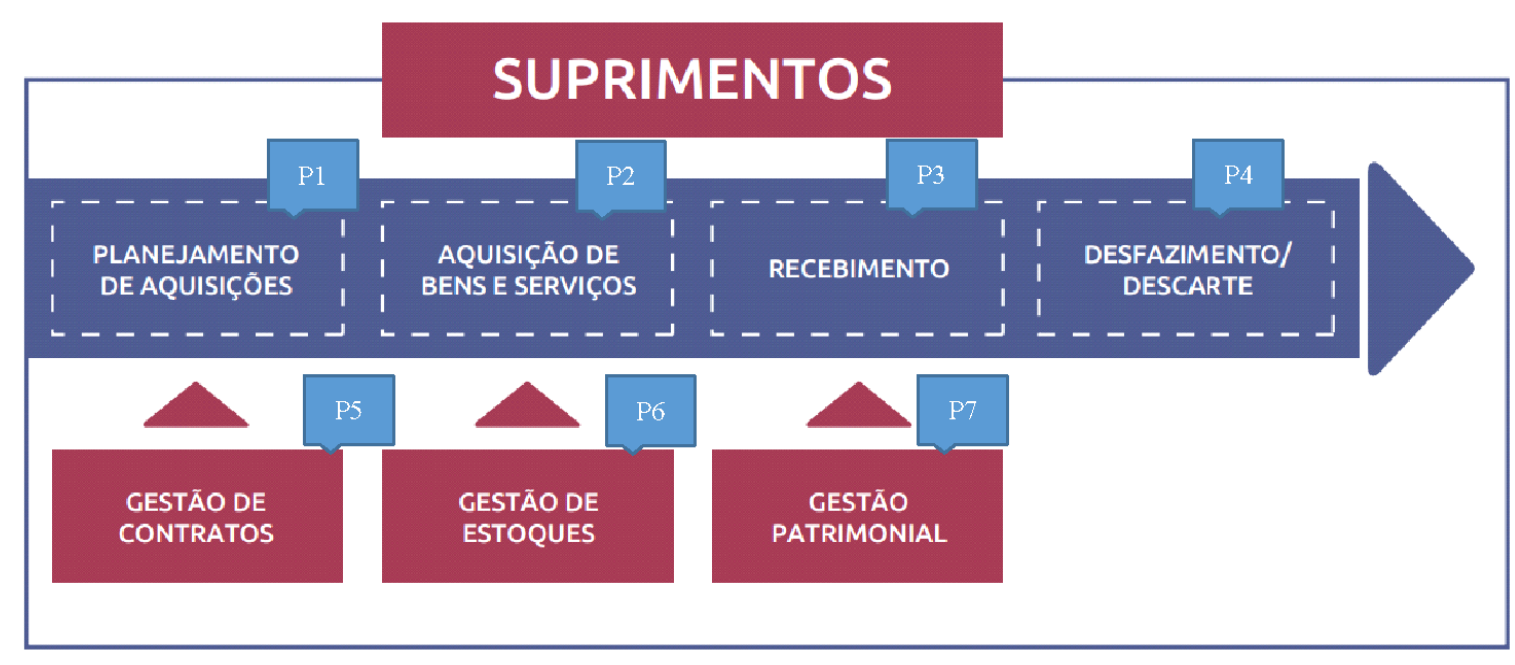

Figura 11: Macroprocesso Suprimentos da UFRGS

Fonte: Adaptado de UFRGS (2020, p. 49) 


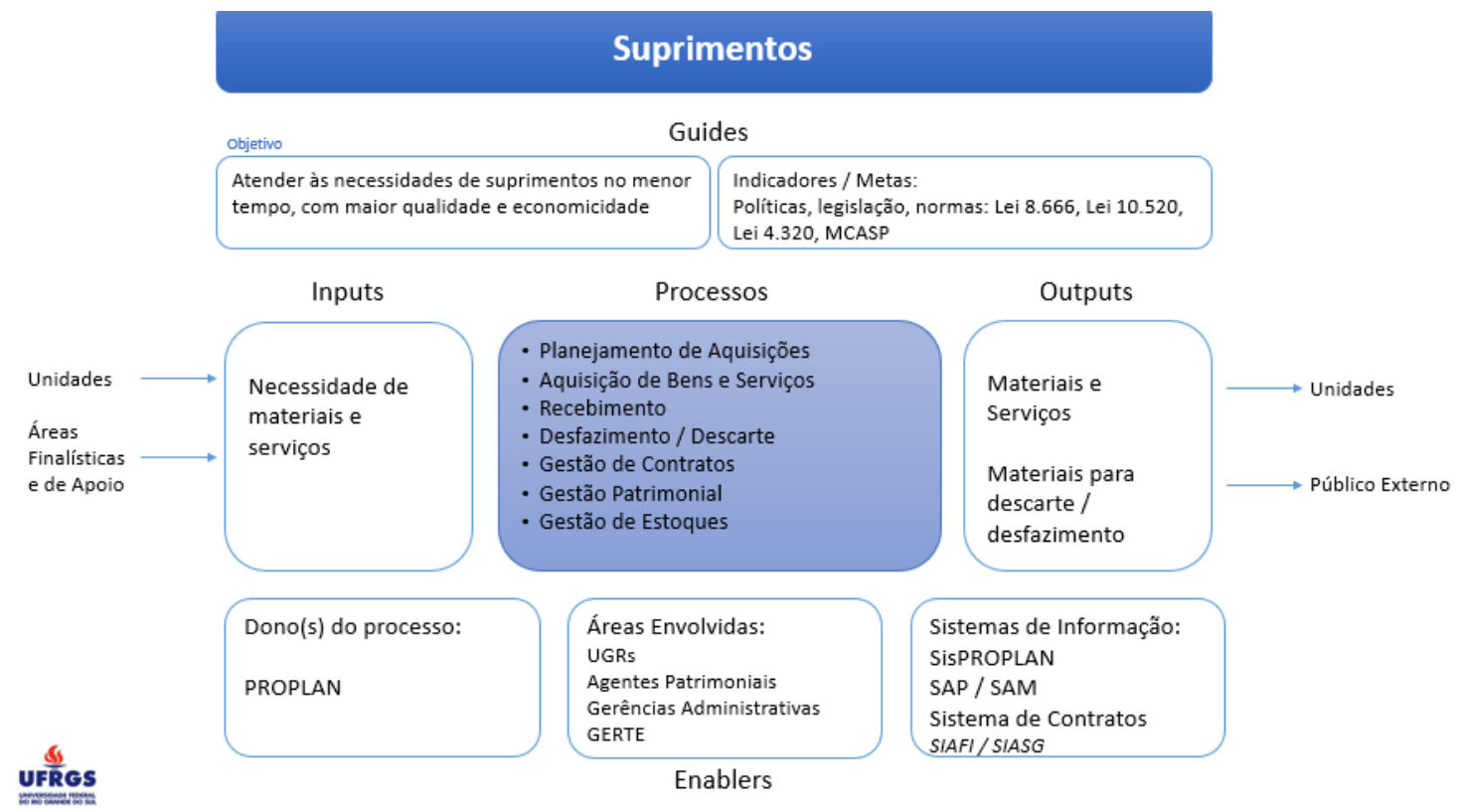

Figura 12: Caracterização SIPOC do Macroprocessos Suprimentos da UFRGS

Fonte: Branco (2016, p. 85)

O foco do estudo estará fixado nos processos Planejamento de Aquisições (P1) e Aquisição de Bens e Serviços (P2), visto serem estes que o DELIT possui a responsabilidade de execução de trabalho. Os demais processos não estarão contemplados neste estudo.

Os processos P1 e P2 são executadas por 10 (dez) servidores do quadro de funcionários da UFRGS dentro do DELIT: 5 (cinco) na DPCA, 2 (dois) na DPL e 3 (três) na DIVLIC, auxiliados por 2 (dois) bolsistas. O Departamento conta com um responsável que chefia e coordena as atividades destas três divisões. A UFRGS não conta atualmente com nenhum sistema dedicado à operacionalização das atividades de aquisições e integrado com os demais sistemas usados na UFRGS, que permita operacionalizar todo o processo internamente.

A Universidade adota o SEI - Sistema Eletrônico de Informações, uma ferramenta de gestão de documentos e processos eletrônicos desenvolvida pelo Tribunal Regional Federal da $4^{\mathrm{a}}$ Região e que integra o Processo Eletrônico Nacional (PEN), iniciativa conjunta de órgãos e entidades de diversas esferas da Administração Pública, que está baseada em um ambiente online e é usada para a tramitação interna de todos os documentos administrativos de forma eletrônica. As informações que são geradas durante o processo são anexadas ao SEI para compor o quadro de informações que a legislação federal exige, não servindo o SEI, todavia, como uma ferramenta de workflow. Uma representação de um processo eletrônico no SEI é apresentada no Anexo 4. 
Neste trabalho será adotada a terminologia "processo SEI" para diferenciar do termo "processo". O processo SEI corresponde à sequência de atos predefinidos de acordo com a legislação em vigor e que se aplica sobre o tema jurídico que se está tratando e o conjunto de todos os documentos que precisam ser apresentados no decorrer do procedimento para a sua correta instrução processual. O procedimento licitatório é o modo pelo qual esses atos processuais devem ser cumpridos, ou seja, o rito que seguirão.

As atividades mapeadas seguem certa sistemática lógica, com atividades dependentes entre si e com um fluxo ordenado de atividades antecedentes e precedentes. Apesar de este fluxo ser claro para os executantes do processo, o mesmo não está materializado em documentos oficiais. As etapas e o fluxo sequencial estão presentes no conhecimento empírico dos servidores do DELIT. Nenhum tipo de controle é feito, atualmente, sobre a execução das atividades. A Figura 13 esquematiza os subprocessos que fazem parte dos processos P1 e P2.

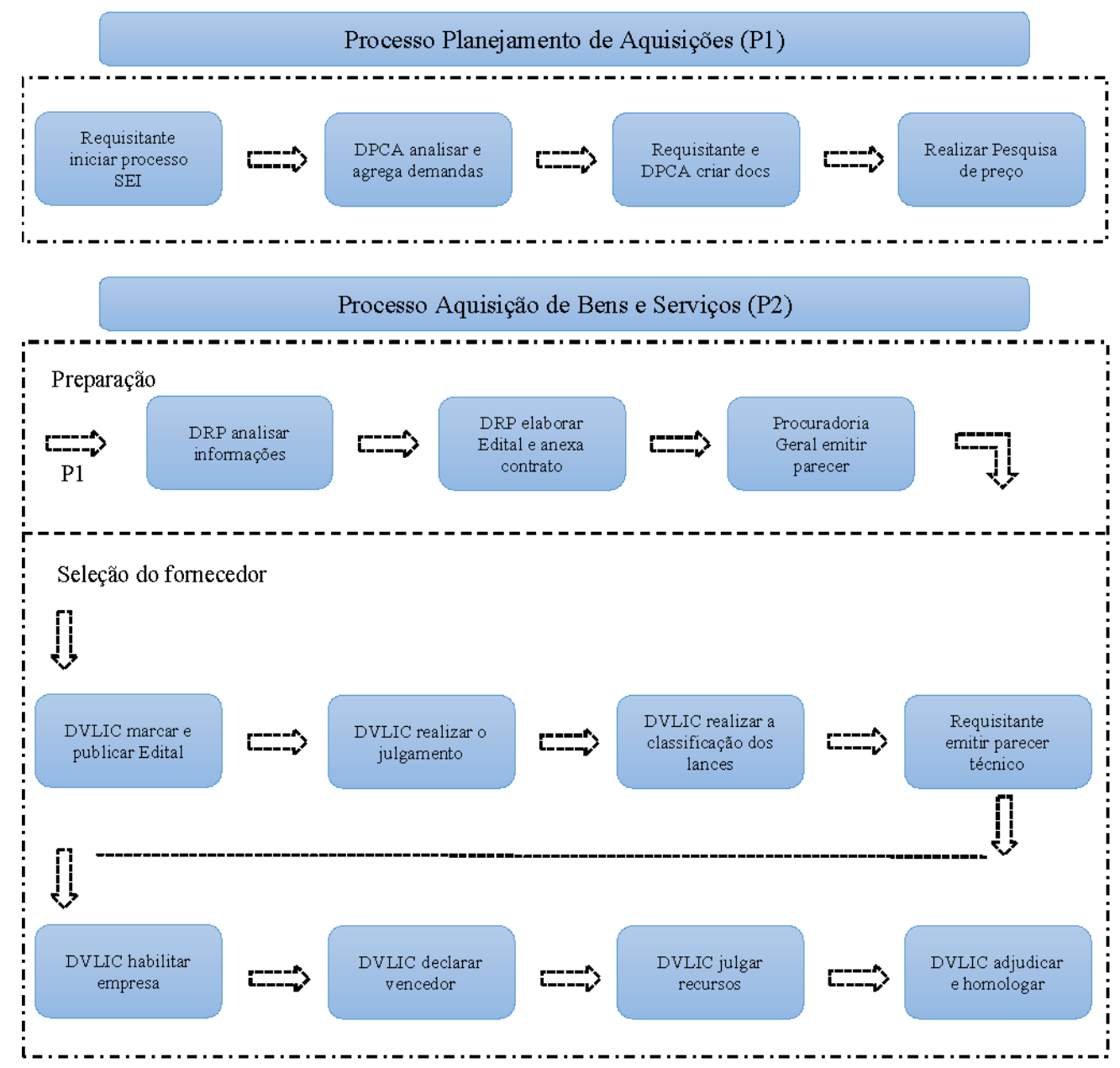

Figura 13: Esquema representativo das principais atividades dos processos P1 e P2 do macroprocesso Suprimentos

Fonte: Elaborado pelo autor 
As tarefas ou as atividades componentes do procedimento licitatório geram algum resultado, que é materializado através de documentos que são gerados e anexados ao sistema eletrônico de processos. Este sistema serve apenas como um organizador estático dos documentos que precisam ser juntados ao processo licitatório e substituiu o modelo antigo de papel. Os resultados gerados são informações, autorizações e análises jurídicas. Estes documentos são gerados nos mais diferentes meios, geralmente através do uso das ferramentas disponíveis no Pacote Office, não existindo um sistema informatizado e integrado com todas as etapas do processo.

O processo P1 inicia com a Unidade Requisitante (um setor da UFRGS que identifica uma necessidade e demanda a compra) iniciando um processo no sistema eletrônico de processos solicitando o início da execução de um procedimento licitatório. O processo SEI é recebido pela DPCA, que faz uma análise prévia da solicitação para avaliar possíveis demandas de outros setores de forma a agregar novas demandas de outras unidades. A seguir, a DPCA elabora, conjuntamente com a Unidade Requisitante, os documentos necessários para a instrução processual, seguindo os regramentos normativos existentes. Atualmente, a UFRGS adota três diferentes categorizações de aquisições, a saber (i) Bens Comuns, (ii) Serviços e (iii) Tecnologia da Informação e Comunicação, sendo que cada uma apresenta legislação ou regulamentação específicas e também legislações correlatas, bem como apresentam formulários específicos, de acordo com a sua categorização, que precisam se confeccionados e anexados no sistema eletrônico de processos. Uma lista exemplificativa com o rol de normas legais existentes aplicadas às compras públicas é apresentada no Quadro 7.

Os formulários foram desenvolvidos internamente pelo DELIT, com o conteúdo baseado nas informações necessárias estipuladas pelos regramentos ou legislações vigentes. Para cada novo processo licitatório, o preenchimento destes documentos é obrigatório, sendo de responsabilidade conjunta da DPCA e da Unidade Requisitante a confecção e a instrução nos autos do processo eletrônico.

Na sequência, é realizada a pesquisa de preços, procedimento de realização obrigatória para todas as aquisições, onde a Administração Pública estipula, através de consultas a preços públicos ou com potenciais fornecedores, o valor máximo a que está disposta a pagar pelo item que está sendo licitado. O chamado valor de referência do item serve como a previsão de quanto será gasto e nenhum item poderá ser homologado com valor superior a este. É sobre este valor 
que as empresas licitantes definem os seus preços para poderem registrar a sua intenção em participar da licitação.

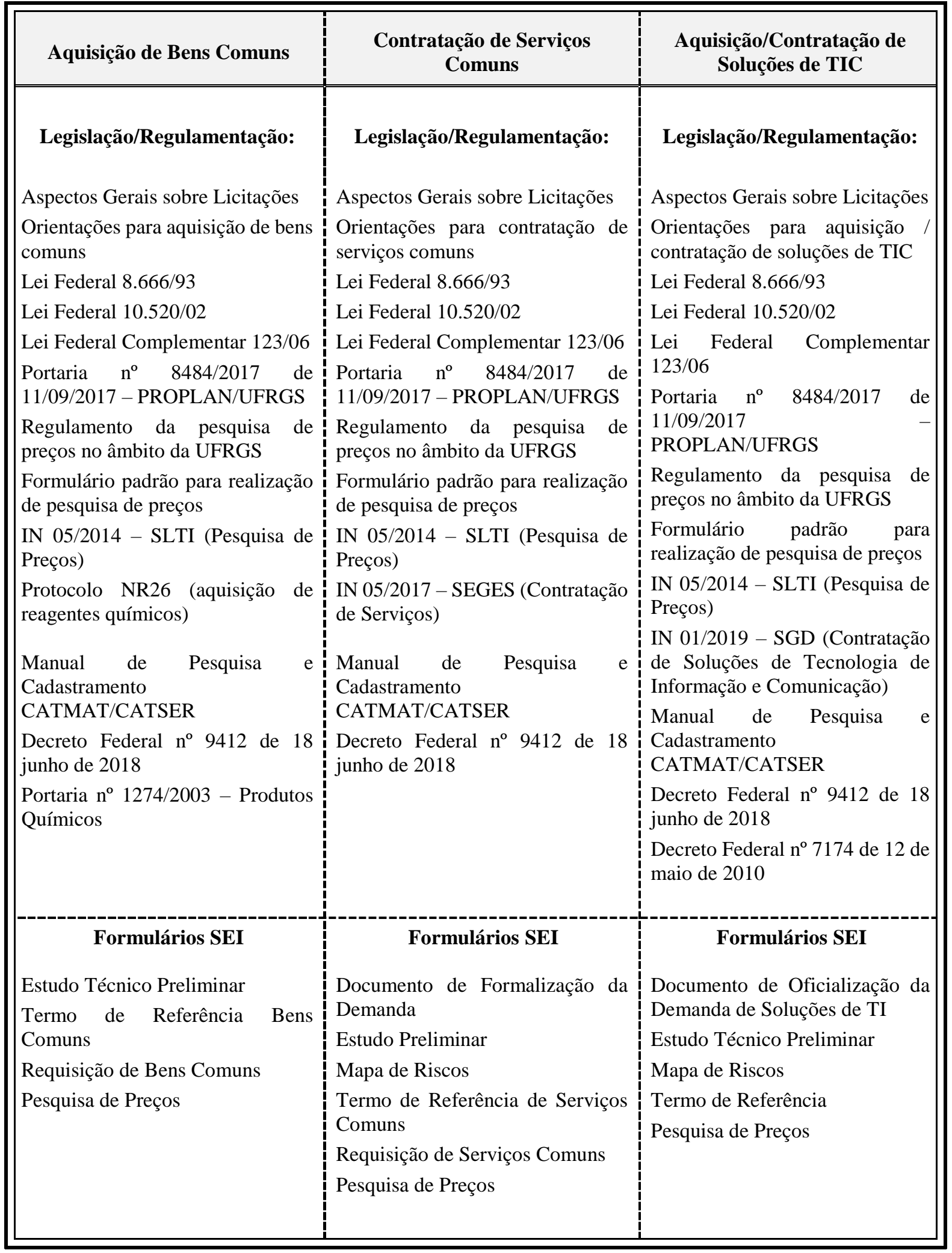

Quadro 7: Legislação/regulamentação existente e o Formulário SEI para o macroprocesso de Suprimentos

Fonte: Elaborado pelo autor 
A seguir, inicia-se o processo de Aquisição (P2), com o processo SEI seguindo para a DPL que, em um primeiro momento, analisa se o processo SEI está instruído corretamente com os documentos obrigatórios. Havendo dúvidas ou incorreções na instrução, o processo SEI é devolvido para as devidas correções que se fizerem necessárias. Não ocorrendo inconsistências, a DPL irá preparar os documentos que servirão como embasamento legal da aquisição e que servem como instrumento formal de comunicação com a comunidade exterior da necessidade de uma aquisição pela UFRGS - o Edital de Licitação e o Contrato ou a Ata de Registro de Preços (para os casos em que haja a necessidade de formalização de instrumento contratual). $\mathrm{O}$ relacionamento entre as partes da cadeia de suprimento, fornecedor - cliente (empresas UFRGS), pode se dar por meio de Contrato ou por Ata de Registro de Preços, ambos estabelecidos pelo edital licitatório, onde estão descritas todas as regras legais da relação. Tanto o Contrato quanto a Ata de Registros de Preços possuem duração máxima de 1 (um) ano; após o término deste prazo um novo procedimento licitatório necessita ser realizado para a escolha de novo fornecedor. Estes documentos são preenchidos, também, com informações constantes nos formulários SEI desenvolvidos no processo anterior - Planejamento de Aquisições (P1).

O processo SEI é remetido para a Procuradoria-Geral da UFRGS, órgão executivo e de assessoramento especial subordinado ao Reitor e integrante do sistema jurídico da União no Poder Executivo, e vinculado tecnicamente à Advocacia Geral da União através da Procuradoria-Geral Federal. Este órgão tem por finalidade a execução dos encargos de consultoria e assessoramento jurídico à Administração Universitária, representação judicial e também o de zelar pelo cumprimento das normas legais emanadas do poder público. A Procuradoria-Geral revisa o processo SEI de forma a emitir um parecer jurídico atestando a regularidade formal do procedimento adotado até este momento, verificando o teor dos instrumentos (documentos) constantes no processo SEI (Edital de Licitação e seus anexos) e a existência de atendimento aos requisitos legais. Identificando algum problema, o processo SEI é remetido pela Procuradoria Geral para o DIVLIC verificar qual setor deu origem ao problema indicado, de forma a permitir que o causador do problema resolva e instrua corretamente com as informações solicitadas e corrigidas.

A DIVLIC, na sequência, recebe o processo para dar início ao procedimento de disputa entre os fornecedores interessados. Esta etapa está relacionada à forma como o fornecedor é escolhido através da realização de procedimentos licitatórios que visam selecionar o fornecedor que apresenta a proposta mais vantajosa para a UFRGS, segundo as especificações e critérios contidos no Edital de Licitação. 
Primeiro, são marcados a data e o horário de abertura da sessão pública de licitação, sendo divulgado o Aviso de Realização de Licitação, de maneira concomitante, no sistema federal usado pelos órgãos para o registro, a divulgação e a execução dos atos relativos aos procedimentos licitatórios. Junto com a marcação e o aviso, são tornados públicos também os documentos constantes no processo SEI, permitindo o acesso às informações internas geradas pela UFRGS. A data de abertura da sessão pública de licitação não poderá ser, por lei obrigatoriamente estipulada, inferior a 8 (oito) dias úteis. Devido ao número reduzido de servidores com atribuições de pregoeiro, a regra utilizada é a de não marcar mais de duas sessões públicas de licitação por dia, conforme pode ser visto no Anexo 5.

O número de licitações executadas nos últimos cinco anos está apresentado na Tabela 1 (Anexo 5). Devido à pandemia decorrente do Coronavírus, os dados das licitações realizadas em 2020 não foram considerados neste estudo por apresentarem dados distorcidos devido à redução de atividades presenciais da Universidade.

Tabela 1: Número de licitações executadas a cada ano

\begin{tabular}{c|c|c|c|c|c}
\hline \hline Ano & 2015 & 2016 & 2017 & 2018 & 2019 \\
\hline Número & 238 & 200 & 195 & 175 & 135 \\
\hline \hline
\end{tabular}

Fonte: Elaborado pelo autor

Na data estipulada, um servidor do DIVLIC com atribuições legais de pregoeiro será o responsável por dar início à disputa no sistema e conduzirá a disputa entre as empresas que cadastraram previamente as suas propostas de fornecimento. No caso de não haver propostas cadastradas, o procedimento licitatório é declarado fracassado e o processo SEI é remetido para a Unidade requisitante. Havendo propostas, as mesmas serão analisadas e as que não se enquadrarem nos requisitos estipulados no Edital serão desclassificadas; as propostas julgadas corretas serão classificadas para participação na disputa de preços dentro do período de tempo estipulado no sistema. Após o término do tempo de disputa, os lances são classificados de acordo com o critério de julgamento estipulado no Edital e aceitos pelo pregoeiro; a empresa mais bem classificada deverá registrar, na sequência, uma nova proposta com o valor do lance ofertado e aceito pelo pregoeiro.

O processo SEI é então remetido para a Unidade Requisitante emitir o parecer técnico de aceitabilidade da proposta. Se o parecer técnico for pela não aceitabilidade da proposta, o 
pregoeiro, após o recebimento do processo SEI, procederá com a desclassificação da proposta rejeitada e chamará o segundo colocado na classificação e solicitará o parecer técnico para esta proposta, e assim sucessivamente até haver um parecer pela aceitabilidade da proposta. A licitação é considerada fracassada se todas as propostas forem rejeitadas.

Com a aceitabilidade técnica da proposta, o pregoeiro procederá com a habilitação da empresa onde será verificada a regularização fiscal, econômica e financeira da mesma através da verificação e da emissão de certidões negativas de débitos e de irregularidade fiscal. De posse destas negativas e de toda a documentação que é exigida no Edital, a empresa é declarada provisoriamente vencedora da disputa. Após esta declaração, é aberto pelo pregoeiro o prazo legal para quaisquer interessados ingressarem com recurso contra os atos executados pelo pregoeiro, um direito assegurado por lei.

A intenção de recurso deve ser registrada no sistema dentro de um prazo limite legal de 3 (três) dias para apresentação das razões do recurso, sendo que o pregoeiro registra as suas alegações e, na sequência, às encaminha à autoridade legal (coordenador do Departamento) que analisa o recurso impetrado e as alegações do pregoeiro e decide pelo provimento ou não do recurso. Aceitando-se o recurso, o processo deverá retornar para a etapa anterior que deu causa à existência do recurso para a realização das correções necessárias; negando-se o recurso, o processo segue para as etapas subsequentes.

Após o término do prazo para registro de recursos, o pregoeiro realizará a adjudicação da licitação (ato no qual é declarado o resultado do procedimento licitatório) e o processo SEI será encaminhado para o Diretor do DELIT adjudicar a licitação (ação que atesta que todos os atos foram executados e ratifica o resultado da licitação, de forma definitiva). O processo SEI segue para a execução dos próximos processos, sendo concluída a participação do DELIT. O Anexo 6 demonstra a tela no Comprasnet com o resultado de um processo licitatório.

Os subprocessos que formam o processo P2 são os maiores potencializadores de problemas, pois é nesta etapa que ocorre a disputa entre os interessados em firmar uma relação contratual e financeira com a UFRGS (as empresas). A execução das atividades que compõem os subprocessos integrantes do processo P2 pode terminar com três resultados: a licitação pode ser (i) deserta, (ii) fracassada ou (iii) sucedida. Licitação deserta significa que nenhum fornecedor respondeu ao chamamento público, sendo que nenhuma proposta comercial foi registrada no sistema próprio do Governo Federal e, consequentemente, não haverá disputa 
entre fornecedores. A licitação é tida como fracassada quando, mesmo com possíveis fornecedores registrando a sua proposta de fornecimento, as mesmas não são aceitas por não se enquadrarem nos critérios estabelecidos no Edital de Licitação e a licitação não terá um vencedor. A licitação sucedida é aquela que possui um fornecedor com o status de habilitado para fornecer o bem ou prestar o serviço. As licitações fracassadas ou desertas são relicitadas, reiniciando todo o processo.

A percepção junto aos clientes internos sobre a qualidade do macroprocesso de Suprimentos é geralmente ruim; o procedimento todo é visto como muito demorado e burocrático, com etapas não muito claras e, por vezes, confusas. Além disso, a percepção de que apenas material de baixa qualidade é adquirido devido ao critério de escolha ser pelo menor preço das propostas recebidas é vista como um qualificador do processo.

\subsubsection{Identificação e contexto do problema do processo estudado}

O cenário relacionado aos processos de Planejamento e Aquisição em uma instituição federal de ensino, mais especificamente na UFRGS, que motivou o presente estudo, foi detalhadamente descrito (mesmo que em parte apenas) no item anterior. A conscientização do problema foi construída ao longo de seis anos de observação, sendo que o pesquisador desenvolveu suas atividades no Departamento de Licitações nos últimos três anos, aproximadamente, atuando diretamente com os processos de licitação para a aquisição de bens, insumos e serviços, que são utilizados na manutenção das atividades da Universidade ou adquiridos para o uso docente, sendo colocados à disposição de toda a comunidade universitária, seja para uso o administrativo, seja para a utilização em ensino ou em pesquisa e desenvolvimento científicos.

As dificuldades estão relacionadas, principalmente, à necessidade de aderência do processo interno da UFRGS à legislação relativa à compras públicas e à revisões e adaptações do processo devido às constantes alterações legislativas (por exemplo, a edição de Instruções Normativas que regulamentam o disposto por Decretos Legislativos) e sistêmicas (por exemplo, a implantação, de uso obrigatório, do Sistema ETP Digital no Portal de Compras Governamentais) promovidas pelos órgãos externos aos quais a Instituição Federal está vinculada; às exigências dos órgãos de controle pela adoção dos documentos normalizados desenvolvidos por estes órgãos sendo a sua adoção obrigatória; à estrutura organizacional da instituição, que faz com que o processo tramite por vários setores diferentes existentes, 
demandando tempo para a realização das tarefas. Esses aspectos são agravados, ainda, pela própria natureza do processo de compras apresentar aspectos de variabilidade, sendo que não pode ser afirmado com antecedência o resultado final da licitação.

O procedimento licitatório é visto, dentro da comunidade acadêmica da UFRGS, como extremamente moroso, regrado e ineficiente, devido à longa duração do macroprocesso Suprimentos. Foram realizadas entrevistas abertas e não estruturadas com 10 servidores de carreira da UFRGS de 5 unidades diferentes e que estão envolvidos com os aspectos relativos aos suprimentos das suas respectivas unidades para confirmar a percepção dos mesmos. Estes modelos mais flexíveis de entrevista, em que o entrevistado tem liberdade para discorrer sobre o tema sugerido e é respondido dentro de uma conversação informal, caracterizam-se pela liberdade dada ao entrevistado e permitem explorar mais amplamente uma questão e ainda se aprofundar em pontos específicos do tema de interesse do pesquisador.

Como resultado das observações do pesquisador no seu ambiente de trabalho e das respostas obtidas com as entrevistas, observam-se as seguintes dificuldades: (i) aderência aos regramentos e legislações; (ii) exigências dos órgãos de controles; (iii) a estrutura organizacional da instituição; (iv) os aspectos aleatórios dos resultados e, principalmente, (V) a percepção dos usuários. De forma a mitigar estas dificuldades, foi levantada, como solução, a adoção da Gestão de processos alinhada à Avaliação de desempenho aplicadas no setor público, de forma a propor uma sistemática para a avaliação do desempenho do processo de Compras Públicas da UFRGS, das IFES e dos demais órgãos públicos que se utilizam dos procedimentos licitatórios para a aquisição de bens e serviços.

O processo estudado está dentro do macroprocesso Suprimentos, sendo que a implantação de uma sistemática de medição de desempenho do processo de compras da UFRGS aparece como uma oportunidade para promover a melhoria dos processos relacionados ao macroprocesso Suprimentos, trazendo também a oportunidade de promover a medição do desempenho de um processo de negócio que permita contribuir para o alcance dos objetivos institucionais.

\subsubsection{Contexto da Avaliação de desempenho}

A conscientização do problema relacionado aos temas envolvidos na solução proposta ocorreu a partir de uma revisão da literatura, da vivência do pesquisador, que realiza as suas 
atividades laborais na organização em que o estudo foi conduzido e que executa atividades pertencentes a uma etapa do processo estudado, e da consideração de estudos que trataram dos temas sob a ótica da aplicação em organizações privadas e também em organizações públicas.

A pesquisa demonstrou a pertinência da utilização dos conceitos de avaliação de desempenho de processos em organizações que prestam serviços públicos sem fins lucrativos com os conceitos aplicados consolidados, e que o tema "avaliação de desempenho através do uso de indicadores" também integra o rol de recomendações propostas de adoção pelos órgãos que fiscalizam e controlam o desempenho de instituições públicas. No entanto, a maioria dos estudos não apresentou uma sistemática pela qual fosse possível realizar essa integração dos temas na prática, cabendo, portanto, fazer uma proposição, implantá-la e avaliar seus resultados.

\subsection{SUGESTÃo}

Uma vez concluída a etapa de conscientização do problema, em que foi possível compreender e identificar o problema a ser estudado e conhecer os conceitos relevantes para embasar a construção de uma sistemática capaz de solucioná-lo, deu-se, na sequência, a etapa de sugestão.

Nessa etapa, realizou-se uma busca na literatura disponível sobre os temas que poderiam auxiliar na busca de soluções para o problema identificado. Inicialmente, buscou-se identificar conceitos de gestão de processos e de avaliação de desempenho. Na sequência, foram

procuradas na literatura referências sobre trabalhos e estudos que demonstrassem a possibilidade e a viabilidade de aplicação destes temas também em organizações públicas, sendo encontradas várias referências de aplicação em órgãos das diferentes esferas públicas: federal, estadual e municipal, conforme visto na Figura 14. 


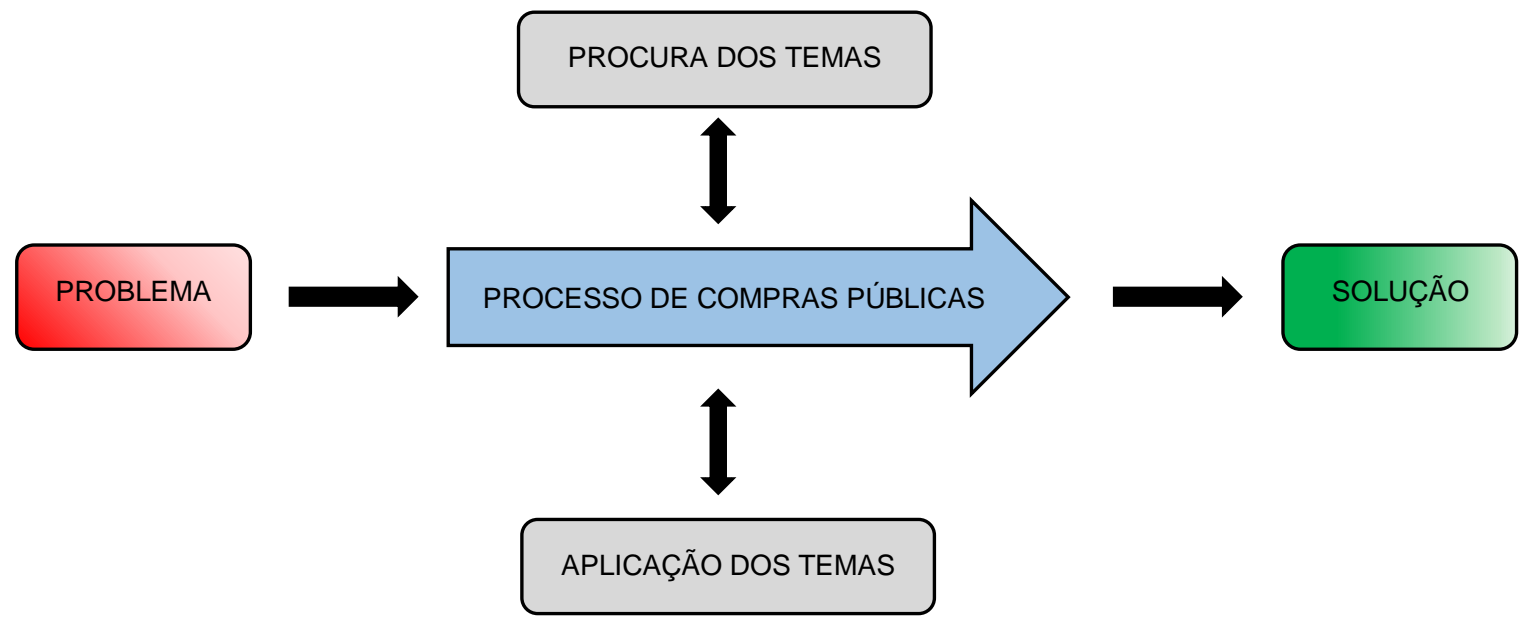

Figura 14: Sugestões planejadas para a execução do estudo

Fonte: Elaborado pelo autor

Posteriormente, a tentativa se direcionou no sentido de encontrar aplicações dos temas teóricos estudados em outros órgãos de maneira mais específica, debruçando-se sobre o processo alvo de estudo (processo de compras públicas) que também faz parte dos macroprocessos de outros órgãos públicos, conforme visto na Figura 15.

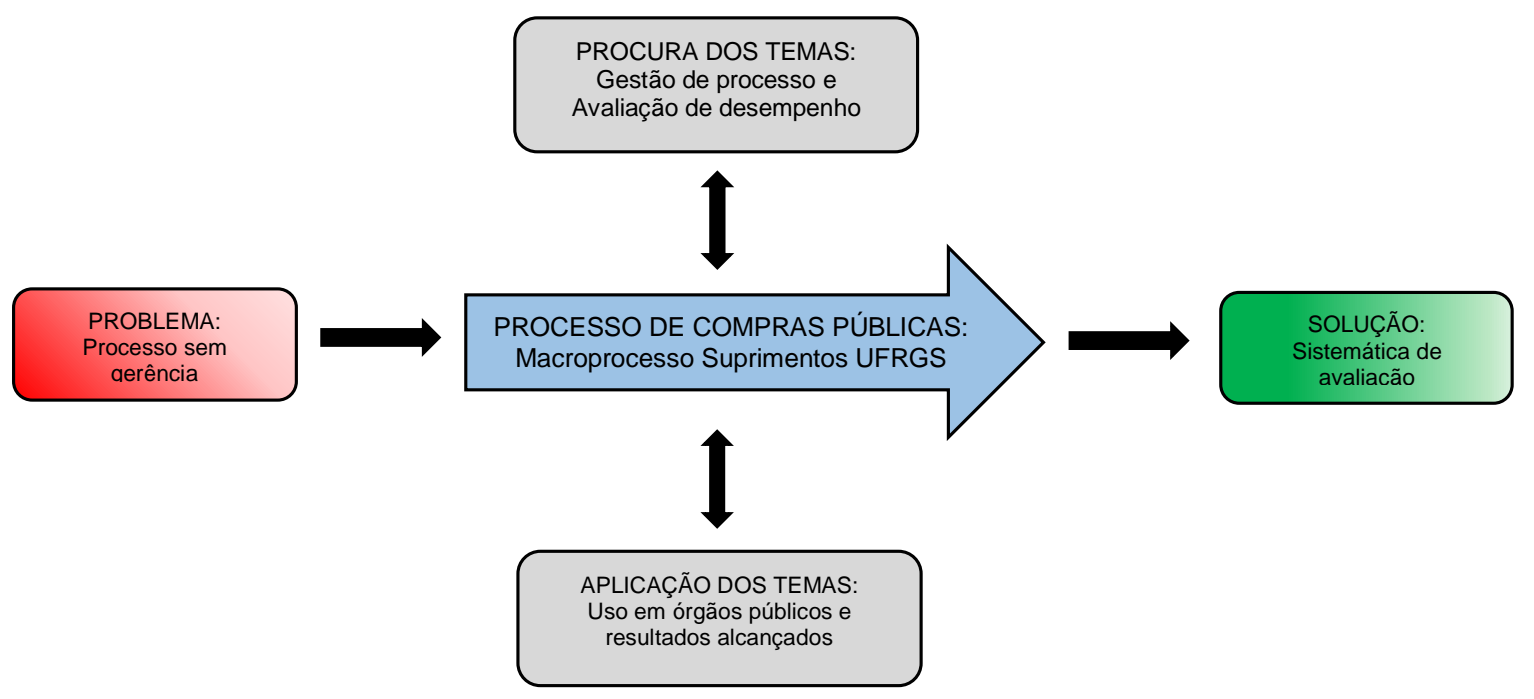

Figura 15: Sugestão das ações planejadas para a execução no processo de estudo

Fonte: Elaborado pelo autor a partir da Figura 14

Os resultados da pesquisa demonstraram que a utilização de uma sistemática de medição de desempenho realizada através do uso de indicadores aplicados sobre um processo específico de um órgão público é viável de ser adotada. No entanto, a pesquisa demonstrou que os estudos sobre a utilização desses dois temas ainda são incipientes, concentrando-se principalmente em abordagens teóricas que buscam identificar fatores que demonstrem o 
benefício da aplicação dos temas no órgão, ao estado da arte, entre outras variáveis que demonstram a proximidade entre os dois temas, sem, contudo, apresentar uma sistemática por meio da qual seja possível realizar, na prática, essa aplicação.

\subsection{DeSENVOLVIMENTo DA Sistemática}

Nesta etapa será descrito, especificamente, o desenvolvimento da sistemática em si. Serão apresentadas as premissas e a lógica de orientação para o seu desenvolvimento, bem como as abordagens teóricas que o embasaram. Ao final, a sistemática é apresentada, com a descrição de suas etapas para posterior aplicação, conforme etapas apresentadas na Figura 16.

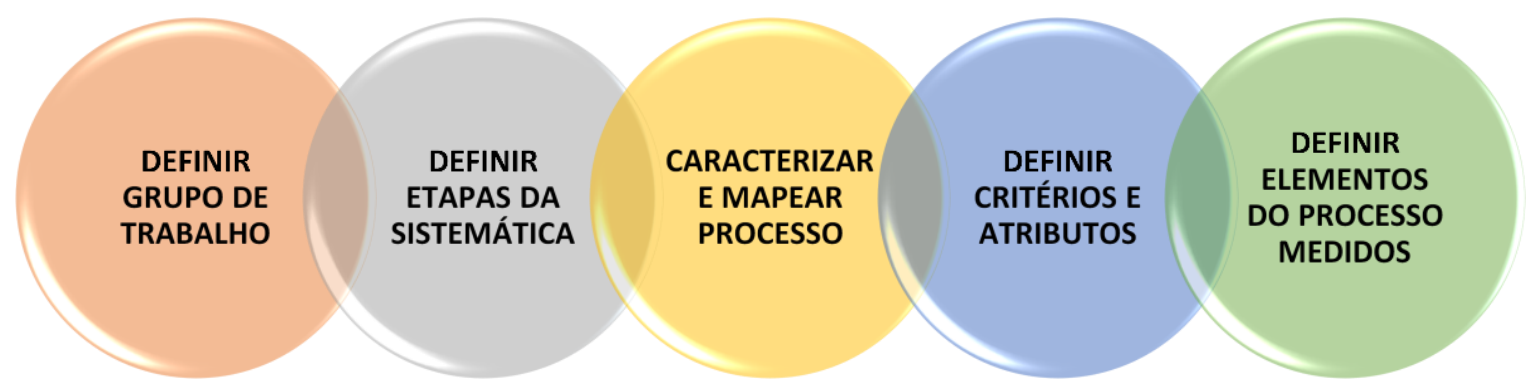

Figura 16: Etapas adotadas para o desenvolvimento da sistemática

Fonte: Elaborado pelo autor

A primeira etapa consiste na definição da equipe que auxiliará no desenvolvimento da sistemática junto ao pesquisador. Recomenda-se que esta equipe seja composta por servidores que trabalham diretamente com o processo estudado. Essa equipe será a responsável pela realização das reuniões, discussões e entrevistas necessárias durante o projeto de construção da sistemática. Finalizado o projeto, esta mesma equipe terá como tarefa implantar a sistemática e mantê-la atualizada e em uso na organização.

Esta equipe que conduzirá o processo de construção da sistemática contará com pessoas do mesmo setor com diferentes níveis hierárquicos e tempo de atuação no DELIT, sendo desejável que a equipe tenha o seguinte perfil: conhecimento em processo e em BPM, para entender e disseminar os objetivos do projeto; experiência em licitação em geral e nos procedimentos licitatórios praticados na UFRGS; e conhecimento da organização como um todo para poder identificar as pessoas chave e os macroprocessos organizacionais, contribuindo para o entendimento do funcionamento da UFRGS. 
Foi proposto um grupo focal com os seguintes servidores do DELIT: 2 servidores da DIVLIC, que são pregoeiros, uma servidora do DPL e também o pesquisador. A primeira discussão do grupo focal foi usada para confirmar as etapas para a construção da sistemática, definir os objetivos e o objeto resultante da etapa e definir os responsáveis pela execução das mesmas, conforme resumido no Quadro 8.

\begin{tabular}{|c|c|c|c|}
\hline Etapa & Objetivo & Objeto & Responsável \\
\hline Caracterizar o processo (SIPOC) & $\begin{array}{l}\text { Entender e delimitar o } \\
\text { processo }\end{array}$ & SIPOC & Grupo focal \\
\hline $\begin{array}{l}\text { Mapear minimamente } \quad \text { o } \\
\text { processo }\end{array}$ & $\begin{array}{l}\text { Analisar o fluxo de atividades } \\
\text { e de tarefas, representando-o } \\
\text { de forma material (gráfica) }\end{array}$ & Processo mapeado & Pesquisador \\
\hline $\begin{array}{l}\text { Definir os indicadores para as } \\
\text { etapas mapeadas que compõem } \\
\text { o processo }\end{array}$ & $\begin{array}{l}\text { Definir os indicadores para os } \\
\text { processos ou subprocessos } \\
\text { mapeados que compõem o } \\
\text { macroprocesso Suprimentos }\end{array}$ & $\begin{array}{l}\text { Mapa de indicadores } \\
\text { provisório }\end{array}$ & Grupo focal \\
\hline $\begin{array}{l}\text { Identificar e levantar a(s) } \\
\text { fonte(s) de dados }\end{array}$ & $\begin{array}{l}\text { Para cada indicador, } \\
\text { identificar a fonte onde o dado } \\
\text { será coletado }\end{array}$ & Mapa de indicadores & Pesquisador \\
\hline Coletar os dados & $\begin{array}{l}\text { Coletar os dados e gerar os } \\
\text { indicadores }\end{array}$ & Planilha de controle & Pesquisador \\
\hline Divulgar os dados processados & $\begin{array}{l}\text { Divulgar o resultado dos } \\
\text { indicadores }\end{array}$ & Mapa de indicadores & Pesquisador \\
\hline $\begin{array}{l}\text { Análise da pertinência dos } \\
\text { resultados processados }\end{array}$ & $\begin{array}{l}\text { Analisar a pertinência dos } \\
\text { resultados obtidos e do uso do } \\
\text { indicador }\end{array}$ & $\begin{array}{l}\text { Mapa de indicadores } \\
\text { definitivo }\end{array}$ & Grupo focal \\
\hline
\end{tabular}

Quadro 8: Resumo das etapas de desenvolvimento da sistemática

Fonte: Elaborado pelo autor

$\mathrm{Na}$ sequência das atividades, o grupo discutiu a caracterização e o mapeamento do processo, culminando na Figura 13 da seção anterior. Atualmente, o DELIT está conduzindo outros projetos de melhoria, sendo um deles o mapeamento dos processos para a construção de manuais e procedimentos internos. Para a condução deste trabalho, o resultado deste mapeamento foi usado como base de partida. Para a determinação dos limites do processo, foi estabelecido como início o envio do processo eletrônico SEI para o DPL pela Unidade Requisitante, que está solicitando a aquisição e o término do processo, sendo a comunicação que deve ser enviada pelo DIVLIC relatando o resultado final da licitação para a Unidade Requisitante.

Os limites de início e final do processo foram assim definidos pelos seguintes motivos: (i) o DELIT não possui gerência sobre a Unidade Requisitante, não permitindo, desta forma, 
ditar o ritmo de duração da execução das atividades antes do processo ser remetido para o DPL e (ii) o DIVLIC devolve o processo eletrônico para a Área Requisitante após todas as atividades estarem concluídas e com o resultado da licitação conhecido de forma definitiva, possibilitando assim o início da etapa de envio da ordem de compra e recebimento da aquisição pela Área Requisitante.

A próxima tarefa do grupo, antes de iniciar com os preparativos para a identificação e elaboração dos indicadores, foi definir quais critérios e quais atributos deveriam ser levados em conta na hora da elaboração dos indicadores.

Os critérios adotados para a definição dos indicadores são os seguintes:

a) privilegiar indicadores que apresentem como resultado índices em vez de números puros;

b) utilizar as 4 (quatro) Perspectivas adotadas pelo TCU: Eficácia, Eficiência, Economicidade e Efetividade;

c) existir pelo menos 1 (um) indicador associado para cada Perspectiva;

d) ser necessário existir pelo menos 1 (um) indicador de contagem do número de processos.

Ainda com relação à construção de indicadores, foi identificada a necessidade de alguns atributos serem levados em conta na hora da definição dos indicadores, sendo necessários o atendimento e a apresentação das seguintes características:

a) representatividade: o indicador deve ser adequado ou próprio para apresentar o resultado da medição do processo em que está sendo usado;

b) atendimento às necessidades de informação das partes interessadas: o indicador deve gerar alguma informação útil que permita a adoção de medidas gerenciais;

c) confiabilidade metodológica: o indicador precisa apresentar uma base lógica de medição e forma de cálculo;

d) confiabilidade da fonte: os dados usados no cálculo do indicador precisar ser coletados em fontes oficiais;

e) apresentação: o indicador precisa apresentar simplicidade, clareza, objetividade, e comunicabilidade fáceis;

f) exequibilidade da mensuração: as ações de medição e cálculo do indicador devem ser simples e fáceis. 
Além de conter estes atributos, o indicador também deve possuir alguns elementos imprescindíveis para torná-lo claro e objetivo (TCU, 2000; Faria, 2017). Com estes elementos é possível desenhar um painel ou quadro no formato de um sistema de indicadores que possibilite a visualização e o monitoramento dos processos. As informações constantes neste quadro deverão ser:

a) o nome do indicador e sua unidade de medida;

b) o detalhamento, de forma clara e concisa, do indicador;

c) a fórmula de cálculo do indicador;

d) o período de medição do indicador;

e) a fonte de consulta para coleta da informação, não podendo ocorrer dados de origem restrita ou sigilosa;

f) o setor responsável pela coleta da informação;

g) a qual perspectiva o indicador está associado.

Para auxiliar nesta etapa, foi elaborado o Quadro 9, que demonstra o nome do elemento e a sua descrição.

\begin{tabular}{|c|c|}
\hline Elemento & Descrição \\
\hline Nome do indicador & $\begin{array}{l}\text { Forma pela qual o indicador será apresentado e conhecido pela } \\
\text { comunidade acadêmica }\end{array}$ \\
\hline Unidade de medida & $\begin{array}{l}\text { Padrão de grandeza escolhido para a mensuração da relação } \\
\text { adotada como indicador e que serve de padrão para eventuais } \\
\text { comparações }\end{array}$ \\
\hline Detalhamento & $\begin{array}{l}\text { Descrição do indicador através da demonstração do elemento que } \\
\text { se deseja mensurar }\end{array}$ \\
\hline Cálculo/Fórmula & $\begin{array}{l}\text { Indicação dos elementos que compõem a fórmula utilizada para } \\
\text { geração dos valores }\end{array}$ \\
\hline Período de medição & $\begin{array}{l}\text { Periodicidade de coleta e apuração para disponibilização do } \\
\text { resultado do indicador }\end{array}$ \\
\hline Fonte de dados & $\begin{array}{l}\text { Local onde será possível coletar os dados necessários para calcular } \\
\text { o indicador }\end{array}$ \\
\hline Unidade Responsável & Setor responsável pela coleta dos dados e do cálculo do indicador \\
\hline Perspectiva & Perspectiva à qual o indicador está relacionado \\
\hline
\end{tabular}

Quadro 9: Descrição dos elementos que os indicadores deverão apresentar

Fonte: Elaborado pelo autor 
O grupo focal discutiu então os elementos da rotina de trabalho do processo que se deseja medir, de forma a obter informações sobre a situação atual e os resultados dos esforços realizados e qual o impacto dos mesmos para o cliente interno, resultando nos indicadores. Considerando-se os processos P1 e P2, mostrados na Figura 13, definiu-se a necessidade de medir:

a) o número de itens homologados, fracassados e desertos;

b) o número de processos de licitações sistêmicas, decorrentes do planejamento realizado pela DPCA;

c) o número de itens homologados que não tiveram a compra efetivada durante o período de vigência do contrato ou da Ata de Registros de preços;

d) a aplicação das políticas de apoio e desenvolvimento às microempresas e às empresas de pequeno porte;

e) a assertividade nas execuções das tarefas processuais licitatórias, por meio do cálculo das repetições ou retrabalho;

f) os recursos administrativos impetrados e os recursos aceitos dos licitantes que acabam por gerar reanálises ou retrabalho;

g) a satisfação dos clientes internos em relação aos processos executados pelo DELIT;

h) a redução dos valores de aquisição em relação ao valor de referência;

i) o tempo de tramitação do procedimento licitatório, calculado desde achegada no DELIT até a comunicação da adjudicação e homologação;

j) o tempo de tramitação do processo P1;

k) o tempo de tramitação do processo P2;

1) o número de procedimentos licitatórios marcados em cada ano.

O pesquisador consolidou as informações definidas até o momento, com o objetivo de estabelecer os objetivos para a medição do processo mapeado, depois os indicadores e o que se almeja medir, seguido pela forma como será realizada a medição através do estabelecimento das fórmulas de cálculo, da periodicidade de medição e do estabelecimento das fontes de consulta dos dados. Estas atividades resultaram nas informações que podem ser vistas no Quadro 10 
A seção 4.4 será dedicada à aplicação da sistemática desenvolvida, através da realização de uma simulação por meio do uso de dados reais coletados sobre uma amostragem de procedimentos licitatórios homologados. 


\begin{tabular}{|c|c|c|c|c|c|c|c|c|}
\hline Identificador & $\begin{array}{l}\text { Nome do } \\
\text { indicador }\end{array}$ & $\begin{array}{l}\text { Unidade } \\
\text { de } \\
\text { medida }\end{array}$ & Detalhamento & Cálculo / Fórmula & $\begin{array}{l}\text { Período de } \\
\text { medição }\end{array}$ & $\begin{array}{l}\text { Fonte de } \\
\text { dados }\end{array}$ & $\begin{array}{l}\text { Unidade } \\
\text { Responsável }\end{array}$ & Dimensão \\
\hline Ind 01 & $\begin{array}{l}\text { Taxa de itens } \\
\text { Homologados }\end{array}$ & $\%$ & $\begin{array}{l}\text { Expressa o percentual de } \\
\text { itens aprovados que } \\
\text { provenham de empresas } \\
\text { declaradas habilitadas para } \\
\text { fornecer o item }\end{array}$ & $\begin{array}{l}\left(\mathrm{N}^{\circ} \text { de Itens Homologados / }\right. \\
\mathrm{N}^{\circ} \text { Total de Itens) x } 100\end{array}$ & Semestral & $\begin{array}{l}\text { Painel de } \\
\text { compras }\end{array}$ & DPCA & Eficácia \\
\hline Ind 02 & $\begin{array}{l}\text { Taxa de itens } \\
\text { Desertos }\end{array}$ & $\%$ & $\begin{array}{l}\text { Expressa o percentual de } \\
\text { itens sem oferta } \\
\text { interessados }\end{array}$ & $\begin{array}{l}\left(\mathrm{N}^{\circ} \text { de Itens Desertos / } \mathrm{N}^{\circ}\right. \\
\text { Total de Itens) x } 100\end{array}$ & Mensal & $\begin{array}{l}\text { Planilha de } \\
\text { controle }\end{array}$ & DELIT & Eficácia \\
\hline Ind 03 & $\begin{array}{l}\text { Taxa de itens } \\
\text { Fracassados }\end{array}$ & $\%$ & $\begin{array}{l}\text { Expressa o percentual de } \\
\text { empresas inabilitadas ou de } \\
\text { propostas desclassificadas }\end{array}$ & $\begin{array}{l}\left(\mathrm{N}^{\circ} \text { de Itens Fracassados / }\right. \\
\mathrm{N}^{\circ} \text { Total de Itens) x } 100\end{array}$ & $\begin{array}{l}\text { Após cada } \\
\text { processo } \\
\text { licitatório }\end{array}$ & $\begin{array}{l}\text { Planilha de } \\
\text { controle }\end{array}$ & DELIT & Eficácia \\
\hline Ind 04 & $\begin{array}{l}\text { Taxa de itens } \\
\text { Revogados }\end{array}$ & $\%$ & $\begin{array}{l}\text { Expressa o percentual de } \\
\text { itens que a administração } \\
\text { não tem mais interesse em } \\
\text { adquirir }\end{array}$ & $\begin{array}{l}\left(\mathrm{N}^{\circ} \text { de Itens Revogados / } \mathrm{N}^{\circ}\right. \\
\text { Total de Itens) x } 100\end{array}$ & Semestral & $\begin{array}{l}\text { Planilha de } \\
\text { controle }\end{array}$ & DELIT & Eficácia \\
\hline Ind 05 & $\begin{array}{l}\text { Índice de } \\
\text { compras } \\
\text { sistêmicas }\end{array}$ & $\%$ & $\begin{array}{l}\text { Expressa o percentual de } \\
\text { itens que compõem } \\
\text { licitações sistêmicas }\end{array}$ & $\begin{array}{l}\text { ( } \mathrm{N}^{\circ} \text { de licitações sistêmicas } \\
/ \mathrm{N}^{\circ} \text { total de licitações) } \mathrm{x} \\
100\end{array}$ & Mensal & $\begin{array}{l}\text { Painel de } \\
\text { compras }\end{array}$ & DPCA & Eficiência \\
\hline Ind 06 & $\begin{array}{l}\text { Índice de itens } \\
\text { homologados } \\
\text { para ME/EPP }\end{array}$ & $\%$ & $\begin{array}{l}\text { Expressa o percentual de } \\
\text { itens homologados para } \\
\text { empresas do tipo ME/EPP }\end{array}$ & $\begin{array}{l}\left(\mathrm{N}^{\circ} \text { de Itens homologados }\right. \\
\text { para empresa ME/EPP / } \mathrm{N}^{\circ} \\
\text { Total de Itens) } \times 100\end{array}$ & Semestral & $\begin{array}{l}\text { Planilha de } \\
\text { controle }\end{array}$ & DELIT & Eficácia \\
\hline
\end{tabular}




\begin{tabular}{|c|c|c|c|c|c|c|c|c|}
\hline Ind 07 & $\begin{array}{l}\text { Índice de } \\
\text { assertividade } \\
\text { da instrução } \\
\text { processual }\end{array}$ & $\%$ & $\begin{array}{l}\text { Verificar se o processo é } \\
\text { instruído corretamente ou } \\
\text { precisa ser devolvido para } \\
\text { correções }\end{array}$ & $\begin{array}{l}\text { ( } \mathrm{N}^{\mathrm{o}} \text { de processos que são } \\
\text { devolvidos para correções } \\
\text { e esclarecimentos / } \mathrm{N}^{\circ} \text { total } \\
\text { de processos) x } 100\end{array}$ & Mensal & $\begin{array}{l}\text { Planilha de } \\
\text { controle }\end{array}$ & DELIT & Eficácia \\
\hline Ind 08 & $\begin{array}{l}\text { Índice de } \\
\text { recursos } \\
\text { impetrados }\end{array}$ & $\%$ & $\begin{array}{l}\text { Verificar se o processo teve } \\
\text { recursos impetrados pelas } \\
\text { empresas licitantes }\end{array}$ & $\begin{array}{l}\left(\mathrm{N}^{\mathrm{o}} \text { de processos com }\right. \\
\text { recursos impetrados / } \mathrm{N}^{\mathrm{o}} \\
\text { total de processos) x } 100\end{array}$ & Mensal & $\begin{array}{l}\text { Planilha de } \\
\text { controle }\end{array}$ & DELIT & Eficácia \\
\hline Ind 09 & $\begin{array}{l}\text { Índice de } \\
\text { recursos } \\
\text { impetrados } \\
\text { aceitos }\end{array}$ & $\%$ & $\begin{array}{l}\text { Verificar se o processo teve } \\
\text { recursos impetrados pelas } \\
\text { empresas licitantes aceitos }\end{array}$ & $\begin{array}{l}\left(\mathrm{N}^{\mathrm{o}} \text { de processos com }\right. \\
\text { recursos impetrados } \\
\text { aceitos / } \mathrm{N}^{\mathrm{o}} \text { total de } \\
\text { processos }) \times 100\end{array}$ & Mensal & $\begin{array}{l}\text { Planilha de } \\
\text { controle }\end{array}$ & DELIT & Eficácia \\
\hline Ind 10 & $\begin{array}{l}\text { Satisfação dos } \\
\text { clientes }\end{array}$ & $\begin{array}{c}\text { nível de } \\
\text { satisfação }\end{array}$ & $\begin{array}{l}\text { Analisar a satisfação dos } \\
\text { clientes requisitantes dos } \\
\text { processos licitatórios }\end{array}$ & $\begin{array}{l}\text { Nível de satisfação obtido } \\
\text { através da pesquisa de } \\
\text { satisfação do processo de } \\
\text { licitação baseado no } \\
\text { Customer Satisfaction } \\
\text { Score (CSAT): soma das } \\
\text { notas atribuídas CSAT / N } \\
\text { total de processos }\end{array}$ & $\begin{array}{l}\text { Após cada } \\
\text { processo } \\
\text { licitatório }\end{array}$ & $\begin{array}{l}\text { Pesquisa de } \\
\text { satisfação }\end{array}$ & DPCA & Efetividade \\
\hline Ind 11 & $\begin{array}{l}\text { Economicidade } \\
\text { da aquisição }\end{array}$ & $\%$ & $\begin{array}{l}\text { Expressa a redução do valor } \\
\text { homologado do item após o } \\
\text { procedimento licitatório }\end{array}$ & $\begin{array}{l}\text { (Valor total do item } \\
\text { homologado/ Valor total } \\
\text { estimado do item) x } 100\end{array}$ & Mensal & $\begin{array}{l}\text { Planilha de } \\
\text { controle }\end{array}$ & DELIT & Economicidade \\
\hline Ind 12 & $\begin{array}{l}\text { Tempo de } \\
\text { tramitação do } \\
\text { processo } \\
\text { licitatório }\end{array}$ & dias & $\begin{array}{l}\text { Expressa o tempo médio } \\
\text { gasto para a conclusão de } \\
\text { um processo licitatório }\end{array}$ & $\begin{array}{l}\text { Tempo médio em dias } \\
\text { desde o recebimento do } \\
\text { processo no DPL até a data } \\
\text { de adjudicação da licitação } \\
\text { (Tempo médio = somatório } \\
\text { do tempo total dos } \\
\text { processos licitatórios / } \\
\text { número de processos) }\end{array}$ & Mensal & $\begin{array}{l}\text { Planilha de } \\
\text { controle }\end{array}$ & DELIT & Eficiência \\
\hline
\end{tabular}




\begin{tabular}{|c|c|c|c|c|c|c|c|c|}
\hline Ind 13 & $\begin{array}{l}\text { Tempo de } \\
\text { tramitação de } \\
\text { processo P1 }\end{array}$ & dias & $\begin{array}{l}\text { Monitorar o tempo médio de } \\
\text { processo e verificar se há } \\
\text { alguma morosidade ou } \\
\text { gargalo no processo P1 } \\
\text { Planejamento de Aquisições }\end{array}$ & $\begin{array}{l}\text { Tempo médio em dias } \\
\text { desde a abertura do } \\
\text { processo licitatório até a } \\
\text { conclusão da pesquisa de } \\
\text { preços (somatório tempo } \\
\text { abertura do processo } \\
\text { licitatório até a conclusão } \\
\text { da pesquisa de preços / } \\
\text { número de processos) }\end{array}$ & Mensal & $\begin{array}{l}\text { Planilha de } \\
\text { controle }\end{array}$ & DPCA & Eficiência \\
\hline Ind 14 & $\begin{array}{l}\text { Tempo de } \\
\text { tramitação de } \\
\text { processo P2 }\end{array}$ & dias & $\begin{array}{l}\text { Monitorar o tempo médio de } \\
\text { processo e verificar se há } \\
\text { alguma morosidade ou } \\
\text { gargalo no processo P2 } \\
\text { Aquisição de Bens e } \\
\text { Serviços }\end{array}$ & $\begin{array}{l}\text { Tempo médio em dias } \\
\text { desde a chegada do } \\
\text { processo licitatório na DPL } \\
\text { até a homologação } \\
\text { (somatório tempo abertura } \\
\text { do processo licitatório até } \\
\text { homologação da licitação / } \\
\text { número de processos) }\end{array}$ & Mensal & $\begin{array}{l}\text { Planilha de } \\
\text { controle }\end{array}$ & DELIT & Eficiência \\
\hline Ind 15 & $\begin{array}{l}\text { Número de } \\
\text { processos } \\
\text { licitatórios } \\
\text { agendados }\end{array}$ & número & $\begin{array}{l}\text { Monitorar o número de } \\
\text { procedimentos licitatórios } \\
\text { agendados }\end{array}$ & $\begin{array}{l}\text { Número de processos } \\
\text { licitatórios agendados no } \\
\text { sistema Comprasnet }\end{array}$ & Trimestral & $\begin{array}{l}\text { Planilha de } \\
\text { controle }\end{array}$ & DELIT & Eficiência \\
\hline
\end{tabular}

Quadro 10: Indicadores de Avaliação e Monitoramento do Desempenho do Processo de Compras Públicas sugeridos

Fonte: Elaborado pelo autor 


\subsection{AplicaÇão da SiStemática}

Nesta etapa, foi realizada a análise dos indicadores levantados na seção anterior, através da utilização do uso de dados reais de procedimentos licitatórios realizados pela UFRGS. Esta seção está dividida em 4 (quatro) etapas apresentadas na Figura 17: (i) definição do número de processos SEI que terão os dados coletados; (ii) definiçãa e distribuição dos indicadores para coleta dos dados entre os membros do grupo focal; (iii) coleta de dados; e (iv) anotação das impressões das atividades realizadas.

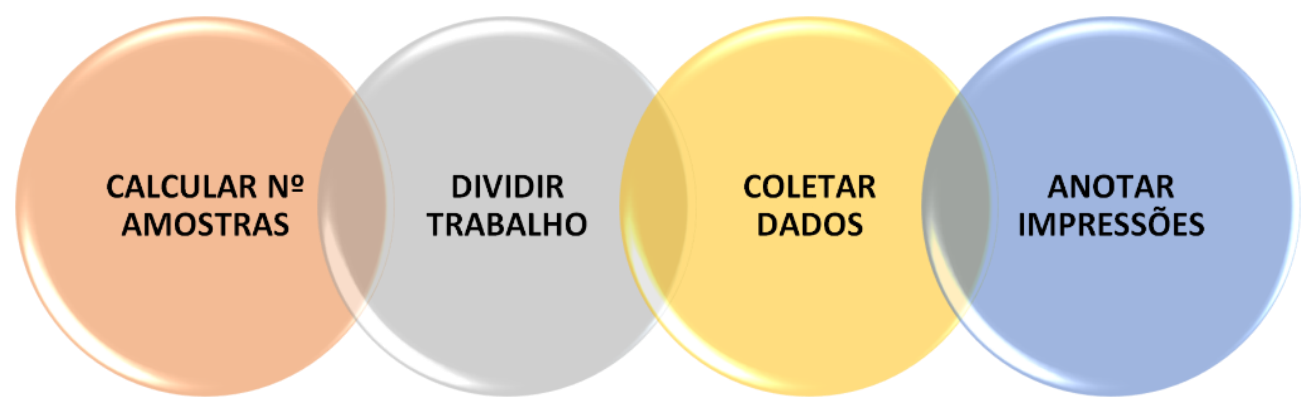

Figura 17: Etapas adotadas para a aplicação da sistemática

Fonte: Elaborado pelo autor

Inicialmente, foi identificada a necessidade de estabelecer quais critérios seriam adotados para a escolha dos processos SEI que seriam selecionados para a coleta dos dados e, consequente, a geração dos indicadores que seriam analisados. Foram estabelecidos e adotados pelo pesquisador os seguintes critérios:

1. Ano de conclusão do processo SEI: o processo deve ter sido concluído (referente à data de adjudicação e homologação) nos anos de 2018 ou de 2019;

2. Número de processos SEI: devem ser escolhidos 12 (doze) processos SEI em cada ano, totalizando 24 (vinte e quatro) processos;

3. Forma de escolha: os processos serão escolhidos de forma aleatória;

4. Período: será selecionado 1 (um) processo concluído em cada mês de cada ano.

Estes critérios foram adotados pelos seguintes motivos: 
1. Os anos mais recentes de conclusão dos processos permitirão usar dados de procedimentos licitatórios executados que sigam os normativos mais recentes e que estejam de acordo com o fluxo do processo mapeado conforme a Figura 13;

2. A amostra de 24 (vinte e quatro) processos SEI foi escolhida por esta etapa servir para testar os conceitos, e este número é entendido como valor representativo dentro do universo de processos. Os esforços em utilizar mais processos SEI não refletiriam no objetivo deste momento, que é o de testar os conceitos, executar a coleta dos dados e das fórmulas de cálculo dos indicadores;

3. A forma aleatória de escolha proporcionará que não ocorra o direcionamento para processos SEI reconhecidos como possuidores de melhores resultados de desempenho;

4. O critério de período e quantidade foi adotado para permitir a distribuição de forma igualitária dos processos SEI durante o período do ano tomado como base.

Para a escolha dos processos, foi utilizada a planilha "Livro DELIT", documento interno do departamento onde todos os processos licitatórios estão registrados, separados de acordo com o ano de execução do procedimento licitatório. Como o departamento não possui um sistema informatizado e os sistemas oficiais governamentais utilizados na execução das tarefas contidas nos processos P1 e P2 não possuem comunicação entre si (por exemplo, SEI, PGC, Comprasnet, ETP digital), esta planilha foi desenvolvida com o objetivo de reunir em um local único os registros dos procedimentos licitatórios executados, de forma a permitir uma rápida localização posterior de informações nos referidos sistemas oficiais.

Para o trabalho de coleta de dados, foi idealizada uma divisão no levantamento dos dados para 3 (três) membros do grupo focal: para o pesquisador, para um servidor do DIVLIC e para uma servidora do DPL. Cada membro ficaria com a responsabilidade de coletar os dados e calcular os indicadores que não apresentam relação com as suas atividades desempenhadas no departamento, contribuindo de forma a verificar quais são realmente as dificuldades com relação ao entendimento dos conceitos dos elementos que fazem parte da fórmula de cálculo e em relação à maneira de proceder com o cálculo do indicador.

O Quadro 11 detalha como foi idealizada a divisão de trabalho para cada membro do grupo focal. 


\begin{tabular}{|l|l|l|}
\hline Membro & Conhecimento/atuação & Indicadores \\
\hline \hline Pesquisador & $\begin{array}{l}\text { BPM; processos; mapeamento. } \\
\text { Atuação: planejamento das } \\
\text { aquisiçães }\end{array}$ & $\begin{array}{l}\text { Resultado final: } \\
\text { Ind 01, Ind 02, Ind 03, Ind 04, Ind 15 }\end{array}$ \\
\hline \hline $\begin{array}{l}\text { Servidor } \\
\text { DIVLIC }\end{array}$ & $\begin{array}{l}\text { Administrativo; leis. } \\
\text { Atuação: executa a licitação } \\
\text { (disputa) }\end{array}$ & $\begin{array}{l}\text { Tempo; retrabalho: } \\
\text { Ind 10, Ind 11, Ind 12, Ind 13, Ind } 14\end{array}$ \\
\hline \hline Servidor DPL & $\begin{array}{l}\text { Administrativo; leis em geral. } \\
\text { Atuação: documentos } \\
\text { preparatórios }\end{array}$ & $\begin{array}{l}\text { Satisfação cliente; aplicação de } \\
\text { políticas públicas: } \\
\text { Ind 05, Ind 06, Ind 07, Ind 08, Ind 09 }\end{array}$ \\
\hline
\end{tabular}

Quadro 11: Divisão do trabalho adotada para a aplicação da sistemática

Fonte: Elaborado pelo autor

Na próxima etapa, foi realizada a coleta dos dados. Seguindo a divisão de tarefas por indicador, cada membro pesquisaria, nas fontes de dados indicadas no Quadro 10 da seção 4.3, os dados que fazem parte da fórmula de cálculo de cada indicador.

As impressões, as dúvidas e os problemas encontrados durante a etapa de coleta de dados também devem ser anotados para serem discutidos com todos os membros do grupo focal, de forma a permitir, com a troca de ideias entre os membros, a criação e a sugestão de melhorias na execução destas atividades. O Quadro 12 demonstra o resultado destas atividades.

Na seção 4.5, será realizada a análise da sistemática adotada, com a análise das impressões dos membros que realizariam a coleta dos dados, dos valores e números calculados (para verificar a acuracidade da fórmula adotada), para a escolha definitiva dos indicadores que farão parte do quadro de indicadores de avaliação e monitoramento. 


\begin{tabular}{|lll|} 
Membro: Pesquisador & \\
Identificador & $\begin{array}{l}\text { Valor } \\
\text { calculado }\end{array}$ & Impressões \\
\hline Ind 01 & $95 \%$ & $\begin{array}{l}\text { Usado o sistema SEI. Necessidade de visualizar a Ata de Realização do Pregão } \\
\text { Eletrônico para coletar o dado. }\end{array}$ \\
\hline Ind 02 & $2 \%$ & $\begin{array}{l}\text { Usado o sistema SEI. Necessidade de visualizar a Ata de Realização do Pregão } \\
\text { Eletrônico para coletar o dado. }\end{array}$ \\
\hline Ind 03 & $3 \%$ & $\begin{array}{l}\text { Usado o sistema SEI. Necessidade de visualizar a Ata de Realização do Pregão } \\
\text { Eletrônico para coletar o dado. }\end{array}$ \\
\hline Ind 04 & $2 \%$ & Usado a planilha de controle interna da DPCA "Registro de Atas de RP”. \\
\hline Ind 15 & - & $\begin{array}{l}\text { Indicador não mensurável nesta etapa: cálculo inviabilizado devido à utilização } \\
\text { de amostra e não do número de processos SEI na totalidade do período. }\end{array}$
\end{tabular}

Membro: Membro equipe e Pesquisador

\begin{tabular}{|lll|} 
Identificador & $\begin{array}{l}\text { Valor } \\
\text { calculado }\end{array}$ & Impressões \\
\hline Ind 10 & - & $\begin{array}{l}\text { Indicador não mensurável nesta etapa: cálculo inviabilizado pois atualmente } \\
\text { não existem dados de medição da satisfação dos requisitantes após o processo } \\
\text { ser concluído no DELIT. }\end{array}$ \\
\hline Ind 11 & $38 \%$ & $\begin{array}{l}\text { Usado o sistema SEI. Necessidade de visualizar a Ata de Realização do Pregão } \\
\text { Eletrônico e o Termo de referência para coletar o dado. }\end{array}$ \\
\hline Ind 12 & 105 dias & $\begin{array}{l}\text { Usado o sistema SEI. Necessidade de entender onde começa e onde termina o } \\
\text { processo. }\end{array}$ \\
\hline Ind 13 & 35 dias & $\begin{array}{l}\text { Usado o sistema SEI. Necessidade de entender onde começa e onde termina o } \\
\text { processo. Registros de documentos fora de ordem dificultaram o entendimento } \\
\text { do fluxo. }\end{array}$ \\
\hline Ind 14 & 69 dias & $\begin{array}{l}\text { Usado o sistema SEI. Necessidade de entender onde começa e onde termina o } \\
\text { processo. }\end{array}$ \\
\hline
\end{tabular}

\section{Membro: Membro equipe e Pesquisador}

\begin{tabular}{|lll|} 
Identificador & $\begin{array}{l}\text { Valor } \\
\text { calculado }\end{array}$ & Impressões \\
\hline Ind 05 & $22 \%$ & $\begin{array}{l}\text { Usado o sistema SEI, localizando o documento que inicia os processos } \\
\text { licitatórios. }\end{array}$ \\
\hline Ind 06 & $25 \%$ & $\begin{array}{l}\text { Usado o sistema SEI. Dado coletado da Ata de Registro de Preço e/ou } \\
\text { Contrato, pois o Comprasnet mostra o nome completo do fornecedor em } \\
\text { formato reduzido. }\end{array}$ \\
\hline Ind 07 & $75 \%$ & Usado o sistema SEI. Necessidade de entender o fluxo do processo. \\
\hline Ind 08 & $18 \%$ & $\begin{array}{l}\text { Usado o sistema SEI. A informação é gerada pelo Comprasnet e depois é } \\
\text { anexada no SEI em formato de documento externo. }\end{array}$ \\
\hline Ind 09 & $5 \%$ & $\begin{array}{l}\text { Usado o sistema SEI. A informação é gerada pelo Comprasnet e depois é } \\
\text { anexada ao SEI em formato de documento externo. }\end{array}$ \\
\hline
\end{tabular}

Quadro 12: Resultado obtido durante a etapa de coleta de dados

Fonte: Elaborado pelo autor 


\subsection{Avaliação da Sistemática e ReSultados}

Nesta última etapa, foi realizada a avaliação da aplicação dos indicadores levantados na seção anterior, através da utilização de dados reais de procedimentos licitatórios realizados pela UFRGS de maneira a permitir formar uma visão crítica da sistemática executada e avaliar o seu comportamento em relação ao ambiente para o qual foi projetado, bem como a sua adequação para a solução do problema identificado. Esta seção está dividida em 4 (quatro) etapas: (i) análise dos dados calculados; (ii) análise e debate a respeito das impressões coletadas e das dificuldades apontadas durante as atividades do levantamento de dados; (iii) deliberação a respeito de cada indicador; e (iv) montagem do quadro final com os indicadores definitivos, conforme etapas apresentadas na Figura 18.

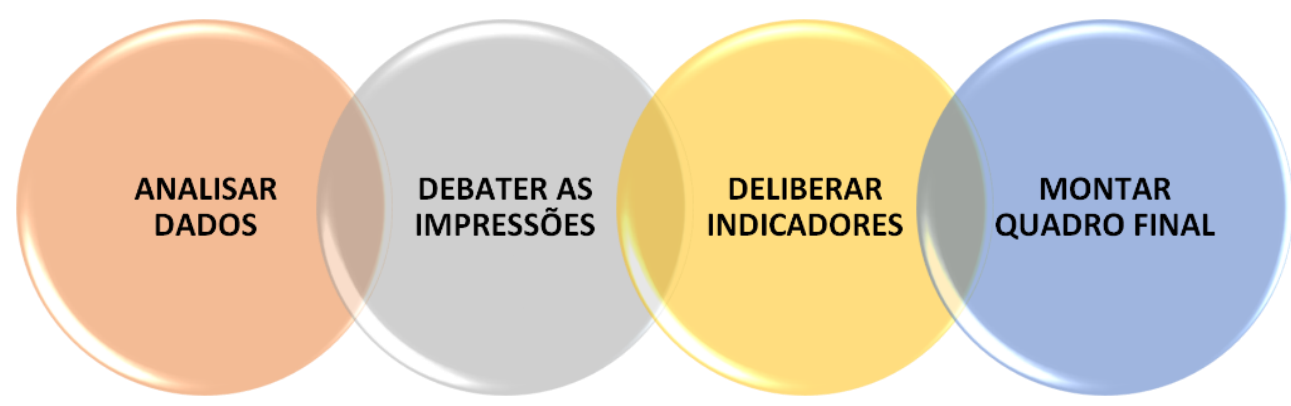

Figura 18: Etapas adotadas para a avaliação da sistemática e dos resultados obtidos

Fonte: Elaborado pelo autor

O cenário atual de restrições e suspensões de atividades devido à pandemia decorrente do Coronavírus limitaram as atividades em grupo de todos os membros do grupo focal; por isto foram realizadas discussões e debates individualizados devido à falta de compatibilidade de agenda dos membros sendo os resultados coletados e agrupados pelo pesquisador.

O grupo focal se reuniria para a validação dos indicadores, iniciando pela análise dos dados e resultados obtidos pelo cálculo de cada indicador. O grupo tinha também como objetivo validar a sistemática com as contribuições dos servidores que realizaram as atividades de coleta de dados através do relato e discussão das impressões, das dúvidas e das dificuldades enfrentadas durante as atividades, o que servirá de embasamento para ajustes na sistemática. As conversas e discussões com os membros do grupo ratificaram que todos os indicadores 
apresentados são relevantes e que os elementos da fórmula de cálculo são claros, mensuráveis, objetivos e refletem o elemento a que se referem. O pesquisador ressaltou que o indicador de economicidade da aquisição pode estimular o uso de preços superestimados no cálculo do valor de referência das licitações, por meio da busca por resultados melhores no indicador; o indicador de satisfação de clientes é visto como de difícil aplicação pois depende da interação humana, que envolve a percepção do solicitante e depende da inserção de informações prestadas pelos setores requisitantes.

O número de 15 indicadores apresentados foi considerado satisfatório, porém, foi feita a sugestão de que o Indicador 11 fosse excluído, o que foi aceito pelo grupo, resultando no número definitivo de 14 indicadores. No entendimento geral, a implantação futura destes indicadores auxiliará na percepção do andamento do processo avaliado, permitindo, caso for preciso, a adoção de ações para correção de rumo.

$\mathrm{Na}$ análise realizada, os indicadores mostram-se aptos em retratar as informações a que estavam se referindo e só podem ser usados dentro do macroprocesso em que estão inseridos, não podendo ser aplicados a outros processos, não gerando, desta forma, a possibilidade de haver dúvidas ou dubiedade. A localização e a coleta de todos os dados para a aplicação na fórmula foram possíveis e proporcionaram a identificação de aspectos inerentes ao processo que permitem a tomada de decisões gerenciais a partir destas informações. Quanto à fórmula de cálculo, todas as fórmulas foram identificadas como corretas, não necessitando realizar qualquer ajuste nos termos que compõem a fórmula.

A análise dos indicadores chegou às seguintes conclusões:

a) Os indicadores relacionados ao desempenho e ao resultado do procedimento licitatório (Ind 01, Ind 02 e Ind 03) foram entendidos como úteis e importantes ao permitirem a visualização da eficácia, com foco nos resultados, e da qualidade do serviço feito, ao demonstrar se os esforços na condução do procedimento trouxeram resultados satisfatórios (com a licitação sucedida) ou se o saldo do resultado foi negativo (licitação fracassada ou deserta). A homologação representa o êxito do procedimento licitatório, ao passo que as licitações fracassadas e desertas necessitam ser analisadas criteriosamente para o entendimento das causas que resultaram no insucesso e nos casos em que nenhum fornecedor manifesta interesse em participar da licitação. 
b) O indicador Ind 04 é usado para medir o índice de revogação referente aos itens que foram licitados mas que não tiveram a efetividade da compra por parte da UFRGS antes do término da vigência do Contrato ou da Ata de Registro de Preços. A hipótese de um item ser revogado implica assumir que a Administração não tem mais interesse em adquirir tal item. Esta medição evidencia falhas das ações de planejamento das contratações do órgão decorrentes da inclusão, de forma incorreta e imprecisa, de produtos ou serviços que o órgão estima demandar ou que não tem certeza de quando serão necessários.

c) $\mathrm{O}$ indicador Ind 05 foi avaliado como fundamental. A justificativa para tal é que a adoção da prática de compras sistêmicas tende a gerar redução de custos processuais e melhor distribuição do trabalho, resultando em maior produtividade para a UFRGS ao permitir criar uma divisão ou um escalonamento na execução dos procedimentos licitatórios durante o ano todo. Este indicador será utilizado para medir o número de licitações que são iniciadas a partir da solicitação da DPCA, conforme os registros internos de planejamento das compras que contêm relações de itens (de produtos e de serviços) de uso recorrente e que são costumeiramente demandados pela UFRGS, e também daquelas contratações que apresentam proximidade do término da relação contratual com a Universidade, quando uma nova licitação para escolha e definição de novo fornecedor precisa ser iniciada. Esta escolha possui respaldo também na necessidade da adoção de práticas de planejamento das compras públicas do órgão que vêm sendo exigidas pelos órgãos de controle externo.

d) $\mathrm{O}$ indicador Ind 06 permite medir a participação das empresas enquadradas como ME/EPP nos processos de compras públicas, participação esta estimulada pelo Governo Federal. A fim de criar condições equilibradas de concorrência entre as empresas e na tentativa de impulsionar a atuação das pequenas empresas nos processos licitatórios, foram criadas políticas públicas que estabelecem critérios e condições especiais e diferenciadas para as ME/EPP. Estas políticas foram criadas para criar melhores condições para que as $\mathrm{ME} / \mathrm{EPP}$ possam concorrer com as empresas de médio e grande porte, que 
possuem maiores infraestrutura e recursos, e lhes permite oferecer melhores preços sem grandes prejuízos e de maneira mais justa para todos os envolvidos.

e) Os indicadores relativos à assertividade da execução das tarefas que compõem o procedimento (Ind 07, Ind 08 e Ind 09) propiciam as informações necessárias para a medição do retrabalho ocorrido. A identificação dos setores e das etapas do processo causadores de erros, tanto pela falta de informações ou da documentação obrigatória quanto pela inclusão de elementos informativos errados nos documentos, proporcionará os meios para direcionar os esforços na atuação de desenvolvimento de ações de treinamento com estes setores, de forma a buscar a sua não recorrência futura em outros procedimentos licitatórios.

f) Os indicadores relativos à duração do procedimento (Ind 12, Ind 13 e Ind 14) e à mensuração do tempo despendido pelo DELIT na condução do procedimento foram considerados importantes para a medição da eficiência processual, podendo ser usados como indicativos da produtividade alcançada pela equipe de trabalho pela demonstração da utilização dos recursos disponíveis da melhor forma possível, também servindo como indicativo para o desenvolvimento de estudos de melhoria de processo.

g) O indicador Ind 15 trata do número de procedimentos licitatórios agendados, servindo para calcular a taxa de trabalho dos pregoeiros e dos servidores que os assessoram nas atividades processuais. A importância do conhecimento deste número se dá pelo fato de que cada procedimento licitatório é atribuído a um pregoeiro, que será o único responsável pela execução e condução das atividades do Processo P2 relativas ao sistema próprio do Governo Federal usado para a condução da licitação. Como o DELIT não marca a realização de mais de uma licitação por dia por pregoeiro, o aumento do número de processos poderá demandar a readequação do número de servidores que atuam como pregoeiros e do número de servidores que atuam como equipe de apoio em determinadas atividades burocráticas (como, por exemplo, a emissão de certidões negativas de débitos das empresas licitantes, o acompanhamento do recebimento de documentação dentro do prazo legal estipulado, a instrução da 
documentação contendo os atos executados pelo pregoeiro dentro do sistema SEI, etc.).

h) Não foi possível realizar a medição do indicador Ind 10, relativo à percepção de satisfação dos clientes. Atualmente, não é realizado nenhum esforço no sentido de entender a expectativa e nem de saber sobre a experiência das unidades com o procedimento licitatório. Os sistemas governamentais atuais não trazem dados que permitam mensurar a percepção dos clientes internos (sobre expectativa das unidades requisitantes das licitações) e nem os aspectos relacionados aos resultados, sendo que, muitas vezes, as unidades não conhecem o fluxo e nem os procedimentos do DELIT, não entendendo como o trabalho é realizado. O entendimento foi pela sugestão da sua aplicação e adoção para os procedimentos licitatórios futuros.

i) Após a análise do indicador de economicidade Ind 11, concluiu-se pela sua não utilização, visto que foi de entendimento focal que o resultado calculado não demonstra uma aplicação gerencial real. A medição da redução no valor contratado (decorrente da diferença entre o valor de referência orçado previamente e o valor obtido na licitação) não significaria um ganho monetário para o órgão. O motivo para isto decorre de que a pesquisa de mercado realizada para estipular o valor contratado pode ser realizada de forma incorreta, através do uso de valores superfaturados ou superestimados, incorrendo nas discrepâncias encontradas na diferença entre o valor de referência orçado e o valor contratado.

Por fim, o entendimento do grupo focal foi de que o monitoramento dos indicadores é de fundamental importância para a UFRGS, pois fornece dados que podem ser tratados e utilizados para realizar o acompanhamento e medir a performance do processo estudado, servindo como direcionador das ações de melhoria e para a correção dos desvios de rumos. Dessa forma, o grupo focal destacou a importância da criação de um quadro ou painel de indicadores, considerando-o uma ferramenta interessante para adoção de forma institucional. O Quadro 13 demonstra os indicadores de avaliação e monitoramento do desempenho definitivos. 


\begin{tabular}{|c|c|c|c|c|c|c|c|}
\hline Nome do indicador & $\begin{array}{l}\text { Unidade de } \\
\text { medida }\end{array}$ & Detalhamento & Cálculo / Fórmula & $\begin{array}{l}\text { Período de } \\
\text { medição }\end{array}$ & $\begin{array}{l}\text { Fonte de } \\
\text { dados }\end{array}$ & $\begin{array}{c}\text { Unidade } \\
\text { Responsável }\end{array}$ & Dimensão \\
\hline $\begin{array}{l}\text { Taxa de itens } \\
\text { Homologados }\end{array}$ & $\%$ & $\begin{array}{l}\text { Expressa o percentual de itens } \\
\text { aprovados que provenham de empresas } \\
\text { declaradas habilitadas para fornecer o } \\
\text { item. }\end{array}$ & $\begin{array}{l}\left(\mathrm{N}^{\circ} \text { de Itens Homologados } / \mathrm{N}^{\mathrm{o}}\right. \\
\text { Total de Itens }) \text { x } 100\end{array}$ & Semestral & $\begin{array}{l}\text { Painel de } \\
\text { compras }\end{array}$ & DPCA & Eficácia \\
\hline $\begin{array}{l}\text { Taxa de itens } \\
\text { Desertos }\end{array}$ & $\%$ & $\begin{array}{l}\text { Expressa o percentual de itens sem } \\
\text { oferta e/ou interessados. }\end{array}$ & $\begin{array}{l}\left(\mathrm{N}^{\circ} \text { de Itens Desertos / } \mathrm{N}^{\mathrm{o}} \text { Total }\right. \\
\text { de Itens }) \text { x } 100\end{array}$ & Mensal & $\begin{array}{l}\text { Planilha de } \\
\text { controle }\end{array}$ & DELIT & Eficácia \\
\hline $\begin{array}{l}\text { Taxa de itens } \\
\text { Fracassados }\end{array}$ & $\%$ & $\begin{array}{l}\text { Expressa o percentual de empresas } \\
\text { inabilitadas ou de propostas } \\
\text { desclassificadas. }\end{array}$ & $\begin{array}{l}\left(\mathrm{N}^{\mathrm{o}} \text { de Itens Fracassados } / \mathrm{N}^{\mathrm{o}}\right. \\
\text { Total de Itens }) \text { x } 100\end{array}$ & $\begin{array}{l}\text { Após cada } \\
\text { processo } \\
\text { licitatório }\end{array}$ & $\begin{array}{l}\text { Planilha de } \\
\text { controle }\end{array}$ & DELIT & Eficácia \\
\hline $\begin{array}{l}\text { Taxa de itens } \\
\text { Revogados }\end{array}$ & $\%$ & $\begin{array}{l}\text { Expressa o percentual de itens que a } \\
\text { administração não tem mais interesse } \\
\text { em adquirir. }\end{array}$ & $\begin{array}{l}\left(\mathrm{N}^{\circ} \text { de Itens Revogados } / \mathrm{N}^{\mathrm{o}}\right. \\
\text { Total de Itens }) \times 100\end{array}$ & Semestral & $\begin{array}{l}\text { Planilha de } \\
\text { controle }\end{array}$ & DELIT & Eficácia \\
\hline $\begin{array}{l}\text { Índice de compras } \\
\text { sistêmicas }\end{array}$ & $\%$ & $\begin{array}{l}\text { Expressa o percentual de itens que } \\
\text { compõem licitações sistêmicas. }\end{array}$ & $\begin{array}{l}\left(\mathrm{N}^{\circ} \text { de licitações sistêmicas / } \mathrm{N}^{\circ}\right. \\
\text { total de licitações) x } 100\end{array}$ & Mensal & $\begin{array}{l}\text { Painel de } \\
\text { compras }\end{array}$ & DPCA & Eficiência \\
\hline $\begin{array}{l}\text { Índice de itens } \\
\text { homologados para } \\
\text { ME/EPP }\end{array}$ & $\%$ & $\begin{array}{l}\text { Expressa o percentual de itens } \\
\text { homologados para empresas do tipo } \\
\text { ME/EPP. }\end{array}$ & $\begin{array}{l}\left(\mathrm{N}^{\circ} \text { de Itens homologados para }\right. \\
\text { empresa ME/EPP / } \mathrm{N}^{\circ} \text { Total de } \\
\text { Itens }) \times 100\end{array}$ & Semestral & $\begin{array}{l}\text { Planilha de } \\
\text { controle }\end{array}$ & DELIT & Eficácia \\
\hline $\begin{array}{l}\text { Índice de } \\
\text { assertividade da } \\
\text { instrução processual }\end{array}$ & $\%$ & $\begin{array}{l}\text { Verificar se o processo é instruído } \\
\text { corretamente ou precisa ser devolvido } \\
\text { para correções. }\end{array}$ & $\begin{array}{l}\left(\mathrm{N}^{\circ} \text { de processos que são }\right. \\
\text { devolvidos para correções e } \\
\text { esclarecimentos / } \mathrm{N}^{\mathrm{o}} \text { total de } \\
\text { processos }) \text { x } 100\end{array}$ & Mensal & $\begin{array}{l}\text { Planilha de } \\
\text { controle }\end{array}$ & DELIT & Eficácia \\
\hline $\begin{array}{l}\text { Índice de recursos } \\
\text { impetrados }\end{array}$ & $\%$ & $\begin{array}{l}\text { Verificar se o processo teve recursos } \\
\text { impetrados pelas empresas licitantes }\end{array}$ & $\begin{array}{l}\left(\mathrm{N}^{\circ} \text { de processos com recursos }\right. \\
\text { impetrados } / \mathrm{N}^{\circ} \text { total de } \\
\text { processos }) \times 100\end{array}$ & Mensal & $\begin{array}{l}\text { Planilha de } \\
\text { controle }\end{array}$ & DELIT & Eficácia \\
\hline $\begin{array}{l}\text { Índice de recursos } \\
\text { impetrados aceitos }\end{array}$ & $\%$ & $\begin{array}{l}\text { Verificar se o processo teve recursos } \\
\text { impetrados aceitos pelas empresas } \\
\text { licitantes. }\end{array}$ & $\begin{array}{l}\left(\mathrm{N}^{\circ} \text { de processos com recursos }\right. \\
\text { impetrados aceitos } / \mathrm{N}^{\circ} \text { total de } \\
\text { processos) x } 100\end{array}$ & Mensal & $\begin{array}{l}\text { Planilha de } \\
\text { controle }\end{array}$ & DELIT & Eficácia \\
\hline
\end{tabular}




\begin{tabular}{|c|c|c|c|c|c|c|c|}
\hline $\begin{array}{l}\text { Satisfação dos } \\
\text { clientes }\end{array}$ & $\begin{array}{l}\text { nível de } \\
\text { satisfação }\end{array}$ & $\begin{array}{l}\text { Analisar a satisfação dos clientes } \\
\text { requisitantes dos processos licitatórios. }\end{array}$ & $\begin{array}{l}\text { Nível de satisfação obtido } \\
\text { através da pesquisa de satisfação } \\
\text { do processo de licitação baseado } \\
\text { no Customer Satisfaction Score } \\
\text { (CSAT): soma das notas } \\
\text { atribuídas CSAT / } \mathrm{N}^{\circ} \text { total de } \\
\text { processos }\end{array}$ & $\begin{array}{l}\text { Após cada } \\
\text { processo } \\
\text { licitatório }\end{array}$ & $\begin{array}{l}\text { Pesquisa de } \\
\text { satisfação }\end{array}$ & DPCA & Efetividade \\
\hline $\begin{array}{l}\text { Tempo de tramitação } \\
\text { do processo licitatório }\end{array}$ & dias & $\begin{array}{l}\text { Expressa o tempo médio gasto para a } \\
\text { conclusão de um processo licitatório. }\end{array}$ & $\begin{array}{l}\text { Tempo médio em dias desde o } \\
\text { recebimento do processo no } \\
\text { DPL até a data de adjudicação } \\
\text { da licitação (Tempo médio = } \\
\text { somatório do tempo total dos } \\
\text { processos licitatórios / número } \\
\text { de processos) }\end{array}$ & Mensal & $\begin{array}{l}\text { Planilha de } \\
\text { controle }\end{array}$ & DELIT & Eficiência \\
\hline $\begin{array}{l}\text { Tempo de tramitação } \\
\text { de processo } \mathrm{P} 1\end{array}$ & dias & $\begin{array}{l}\text { Monitorar o tempo médio de processo } \\
\text { e verificar se há alguma morosidade ou } \\
\text { gargalo no processo P1 Planejamento } \\
\text { de Aquisições. }\end{array}$ & $\begin{array}{l}\text { Tempo médio em dias desde a } \\
\text { abertura do processo licitatório } \\
\text { até a conclusão da pesquisa de } \\
\text { preços (somatório tempo } \\
\text { abertura do processo licitatório } \\
\text { até a conclusão da pesquisa de } \\
\text { preços / número de processos) }\end{array}$ & Mensal & $\begin{array}{l}\text { Planilha } \\
\text { controle }\end{array}$ & DPCA & Eficiência \\
\hline $\begin{array}{l}\text { Tempo de tramitação } \\
\text { de processo } \mathrm{P} 2\end{array}$ & dias & $\begin{array}{l}\text { Monitorar o tempo médio de processo } \\
\text { e verificar se há alguma morosidade ou } \\
\text { gargalo no processo P2 Aquisição de } \\
\text { Bens e Serviços. }\end{array}$ & $\begin{array}{l}\text { Tempo médio em dias desde a } \\
\text { chegada do processo licitatório } \\
\text { na DPL até a homologação } \\
\text { (somatório tempo abertura do } \\
\text { processo licitatório até } \\
\text { homologação da licitação / } \\
\text { número de processos) }\end{array}$ & Mensal & $\begin{array}{l}\text { Planilha } \\
\text { controle }\end{array}$ & DELIT & Eficiência \\
\hline $\begin{array}{l}\text { Número de processos } \\
\text { licitatórios agendados }\end{array}$ & número & $\begin{array}{l}\text { Monitorar o número de procedimentos } \\
\text { licitatórios agendados. }\end{array}$ & $\begin{array}{l}\text { Número de processos } \\
\text { licitatórios agendados no } \\
\text { sistema Comprasnet }\end{array}$ & Trimestral & $\begin{array}{l}\text { Planilha de } \\
\text { controle }\end{array}$ & DELIT & Eficiência \\
\hline
\end{tabular}

Quadro 13: Indicadores de Avaliação e Monitoramento do Desempenho do Processo de Compras Públicas definitivos

Fonte: Elaborado pelo autor 


\section{Comentários finais}

O presente capítulo apresenta as conclusões a respeito dos objetivos e do problema de pesquisa, discutindo as principais contribuições e, na sequência, apresenta algumas sugestões para trabalhos futuros.

\subsection{CONCLUSÕES}

O presente trabalho teve como objetivo principal a proposição de uma sistemática de avaliação de desempenho dos processos de compras que utilizam o procedimento licitatório, a partir da relação entre gestão de processos e avaliação de desempenho e da identificação da relação da aplicação destes temas no processo de suprimentos de um órgão público federal. Para isto, foram estabelecidos alguns objetivos específicos, levados a cabo através da aplicação da sistemática junto à organização usada como objeto do estudo para identificar as impressões a respeito da sua aplicabilidade prática, que possibilitaram a sugestão de um quadro com indicadores para uso no processo estudado.

Em relação ao objetivo específico aplicar parcialmente a sistemática proposta no processo escolhido por meio de uma aplicação em uma IFE, foram realizados testes com dados reais de processos licitatórios executados e concluídos na UFRGS com o objetivo de verificar a aderência ou não da sistemática proposta e a possibilidade da efetivação de uso em relação ao processo escolhido.

Em relação ao segundo objetivo específico identificar, junto à organização objeto do estudo, os principais obstáculos enfrentados durante a implantação de uma sistemática de avaliação de desempenho, bem como demais problemas enfrentados pela organização no processo estudado envolvendo estratégia, indicadores e operações, foram realizadas discussões com um grupo focal formado por um número limitado de servidores do órgão em que trabalham, no setor responsável pelas compras da UFRGS, com o objetivo de obter as percepções dos participantes a respeito da viabilidade ou não da sistemática proposta.

Em relação ao terceiro objetivo específico sugerir a adoção de indicadores que possibilitem avaliar o desempenho de um processo de modo que o mesmo se torne aderente às organizações de natureza pública, os trabalhos e as conversas com os membros 
do grupo focal culminaram na elaboração e proposição de um quadro com 14 indicadores para uso na avaliação e no monitoramento do desempenho do processo de compras, quadro este composto com as informações identificadas como necessárias para o uso correto dos indicadores.

Dentre as principais implicações teóricas do trabalho podem ser citadas a (i) implantação da sistemática com foco na medição e avaliação de desempenho de processo pelo uso de indicadores, o que proporcionará a tomada de ações em âmbito gerencial para a correção da condução das atividades que compõem o processo estudado; a (ii) necessidade de manter uma comunicação efetiva entre todos os setores envolvidos no processo licitatório para a condução harmônica do procedimento para evitar erros ou retrabalhos; e (iii) a indispensabilidade da construção de um sistema que sirva não apenas como um banco de dados, mas como um instrumento de gestão que auxilie na tomada de decisões do gestor.

Ao finalizar o trabalho, chega-se à conclusão que, para o desenvolvimento da sistemática, é preciso desenhar e conhecer o processo que se deseja avaliar com a participação coletiva dos envolvidos. A elaboração e o desenvolvimento de um sistema de indicadores para monitorar os processos será de grande utilidade para a sociedade em geral, para a UFRGS e para as demais IFEs, ao nortear a condução e a execução das atividades que compõem o processo na busca por resultados consistentes e alinhados com os objetivos estratégicos da organização.

\subsection{SUgESTÕES PARA TRABALHOS FUTUROS}

Para complementar a sistemática desenvolvida neste trabalho, sugere-se para pesquisas futuras:

1) Implantar a sistemática de forma efetiva na UFRGS, inclusive com o desenvolvimento e estabelecimento de metas para cada indicador;

2) Aplicar a sistemática desenvolvida em outras IFES e em outros órgãos públicos federais, de forma a validar a sistemática também em outros órgãos públicos;

3) Pesquisar junto a outros órgãos de outras esferas, por exemplo, do poder judiciário, para verificar se é realizada a avaliação de desempenho dos processos de compras 
destes órgãos, a fim de coletar as boas práticas e as lições aprendidas nessas instituições;

4) Pesquisar junto a outros órgãos de outras esferas para analisar a existência de outros indicadores, além dos aqui relacionados, que sejam passíveis de inclusão e utilização no quadro de indicadores desenvolvidos para a UFRGS;

5) Adotar um sistema de gerenciamento de workflow que permita definir, gerenciar e executar o fluxo dos processos com o suporte de um software. O sistema SEI adotado na UFRGS facilita a auditoria e organiza os documentos utilizados no decorrer do processo, mas não apresenta o fluxo ou a sequência das atividades, servindo apenas como um organizador de documentos;

6) Gerar modelos das práticas utilizadas por órgãos públicos para a coleta de dados, cálculo e geração dos valores de forma a otimizar o trabalho manual de mensuração de desempenho.

Portanto, a presente pesquisa aponta no sentido de que as organizações públicas podem se valer do uso das boas práticas gerenciais, adaptando-as para as suas realidades de maneira a obterem maior controle sobre os seus resultados, ao analisar as suas rotinas e os seus processos, identificando os pontos passíveis de melhoria e de aperfeiçoamento para ofertar à sociedade serviços eficientes, eficazes e efetivos. 


\section{REFERÊNCIAS}

ABPMP Brasil. BPM CBOK: Guia para o Gerenciamento de Processos de Negócio - Corpo Comum de Conhecimento ABPMP BPM CBOK. V3.0. Association of Business Process Management Professional Brasil, $1^{a}$ edição, 2013.

ADRIANO, Paulo Roberto Ienzura. Processos Licitatórios: Legislação e Formalização. 2013. Dissertação (Mestrado) - Programa de Pós-Graduação em Planejamento e Governança Pública, Universidade Tecnológica Federal do Paraná, Curitiba.

ALIGLERI, Lilian; ALIGLERI, Luiz Antonio; KRUGLIANSKAS, Isak. Gestão industrial e produção sustentável. São Paulo: Saraiva, 2016.

ALVES, Guilherme Krause; NUNES, Rogério da Silva. Avaliação da gestão dos processos de compras: um comparativo entre as universidades públicas catarinenses. In: SIMPÓSIO AVALIAÇÃO DA EDUCAÇÃO SUPERIOR, 3º 2017.Florianópolis. Anais. Santa Catarina: UFSC, 2017.

ARAÚJO, Samuel Souza de. Instrumento de gestão para avaliar o desempenho de uma unidade de licitações: estudo de caso no hospital universitário. Dissertação (mestrado) Universidade Federal de Santa Catarina, Centro Sócio-Econômico, Programa de PósGraduação em Contabilidade, Florianópolis, 2020.

BANDARA, Wasana; ALIBABAEI, Ahmad; AGHDASI, Mohammad (2009). Means of achieving Business Process Management success factors. In: Proceedings of the 4th Mediterranean Conference on Information Systems, 25-27 September 2009, Athens University of Economics and Business, Athens.

BATISTA, M. A. C.; MALDONADO, J. M. S. V. O papel do comprador no processo de compras em instituições públicas de ciência e tecnologia em saúde (C\&T/S). Revista de Administração Pública, v. 42, n. 4, p. 681-699, 2008.

BEZERRA, Maria Clara da Cunha; TAVARES, Maryana Scoralick de Almeida; SILVA, Ricardo Moreira da. Gerenciamento dos processos de negócio: uma análise dos modelos de ciclo de vida BPM. Revista Produção Online, Florianópolis, v. 18, n. 3, p. 796-825, set. 2018.

BORGES, Lorena de Melo; WALTER, Fábio; SANTOS, Luciano Costa. Análise e redesenho de processos no setor público: identificação de melhorias em um processo de compra. HOLOS, [S.1.], v. 1, p. 231-252, fev. 2016.

BRANCO, Gabriela M. Proposta de framework para construção da arquitetura de processos: o caso de uma instituição federal de ensino superior. 2016. 119 f. Dissertação (Mestrado em Engenharia de Produção) - Escola de Engenharia, Universidade Federal do Rio Grande do Sul, Porto Alegre, 2016.

BRASIL. Constituição (1988). Constituição da República Federativa do Brasil. Brasília, DF: Centro Gráfico, 1988. 
BRASIL. Decreto ${ }^{\circ}$ 5.378, de 23 de fevereiro de 2005. Institui o Programa Nacional de Gestão Pública e Desburocratização - GESPÚBLICA e o Comitê Gestor do Programa Nacional de Gestão Pública e Desburocratização, e dá outras providências. Diário Oficial [da] República Federativa do Brasil, Brasília, DF, 24 fev. 2005. Disponível em: http://www.planalto.gov.br/ccivil_03/_ato2004-2006/2005/decreto/d5378.htm. Acessado em 25/04/2020.

BRASIL. Decreto $n^{\circ}$ 9.094, de 17 de julho de 2017. Dispõe sobre a simplificação do atendimento prestado aos usuários dos serviços públicos, ratifica a dispensa do reconhecimento de firma e da autenticação em documentos produzidos no País e institui a Carta de Serviços ao Usuário. Diário Oficial [da] República Federativa do Brasil, Brasília, DF, 18 jul. 2017. Disponível em: http://www.planalto.gov.br/ccivil_03/_Ato20152018/2017/Decreto/D9094.htm\#art25. Acessado em 29/04/2020.

BRASIL. Lei $\mathrm{n}^{\circ}$ 8.666, de 21 de junho de 1993. Regulamenta o art. 37, inciso XXI, da Constituição Federal, institui normas para licitações e contratos da Administração Pública e dá outras providências. Diário Oficial [da] República Federativa do Brasil, Brasília, DF, 08 jun. 1993. Disponível em: http://www.planalto.gov.br/ccivil_03/leis/18666cons.htm. Acessado em 21/01/2021.

BRASIL. Lei ${ }^{\circ}$ 10.520, de 17 de julho de 2002. Institui, no âmbito da União, Estados, Distrito Federal e Municípios, nos termos do art. 37, inciso XXI, da Constituição Federal, modalidade de licitação denominada pregão, para aquisição de bens e serviços comuns, $\mathrm{e}$ dá outras providências. Diário Oficial [da] República Federativa do Brasil, Brasília, DF, 18 jul. 2.002. Disponível em: http://www.planalto.gov.br/ccivil_03/leis/2002/110520.htm. Acessado em 22/01/2021

BRASIL. Ministério do Planejamento, Orçamento e Gestão. Secretaria de Orçamento Federal. Secretaria de Planejamento e Investimentos Estratégicos. Indicadores - Orientações Básicas Aplicadas à Gestão Pública / Ministério do Planejamento, Orçamento e Gestão. Coordenação de Documentação e Informação - Brasília: MP, 2012. 64 p.: il. color.

BRASIL. Ministério do Planejamento, Orçamento e Gestão. Secretaria de Gestão. Melhoria da gestão pública por meio da definição de um guia referencial para medição do desempenho da gestão, e controle para o gerenciamento dos indicadores de eficiência, eficácia e de resultados do Programa Nacional de Gestão Pública e Desburocratização. Produto 4: guia referencial para medição de desempenho e manual para construção de indicadores. Brasília: MP, 2009.

BRITO, Ricardo França de; ALMEIDA, Vera Luci de; BRITO, Adriana Carla Teixeira da Costa. Indicadores de Desempenho em Compras Públicas: o caso de um Hospital Universitário. In: CONGRESSO NACIONAL DE MESTRADOS PROFISSIONAIS EM ADMINISTRAÇÃO PÚBLICA PROFIAP, I, 2016, Curitiba. Anais. Paraná: UTFPR Campus Curitiba, 2016.

BROCKE, Jan vom; SCHMIEDEL, Theresa. (2011). Culture in business process management: A literature review. Business Process Management Journal. $17.357-378$. $10.1108 / 14637151111122383$. 
CAMPOS, Vicente Falconi. TQC: controle da qualidade total (no estilo japonês). 9 ed. Nova Lima: Falconi, 2014. 286p

CAVEDO, Thiago da Silva. Eficiência na gestão universitária: contribuições do sistema de compras na Universidade de Brasília. 2020 .135 f., il. Dissertação (Mestrado Profissional em Economia) - Universidade de Brasília, Brasília, 2020.

CHIAVENATO, Idalberto Gestão da produção: uma abordagem introdutória - 3. ed. Barueri, SP: Manole, 2014.

CORRÊA, Henrique L.; CORRÊA, Carlos A. Administração de produção e operações: manufatura e serviços: uma abordagem estratégica (9a. ed.). São Paulo: Atlas, 2012.

CORRÊA, Marislane de Freitas. Construção de processos a partir de normas externas: um estudo realizado no setor de gestão de contratos terceirizados de serviços contínuos de uma IFES. Dissertação (Mestrado Profissional em Engenharia de Produção) - Universidade Federal do Rio Grande do Sul, Porto Alegre, 2020.

EIRIZ, V., Barbosa, N., Cunha, F. A., Ferreira, V., Binotto, M., \& Dutra, A. A. Avaliação dos serviços de licitação para apoiar a gestão administrativa de órgão público municipal. Revista Brasileira de Gestão e Inovação, v. 4, n. 1, p. 90-111, 2016.

ELLIS, C. A. Workflow Technology. Computer Supported Co-operative Work. M. Beaudouin-Lafon, John Wiley \& Sons, vol. 7, pp. 29-54, 1999.

ENSSLIN, Leonardo; DUTRA, Ademar; KRÜGER, Anna Claudia; ENSSLIN, Sandra. Avaliação de Desempenho no Setor Público: Estudo de Caso em um Tribunal de Justiça. In: SIMPÓSIO DE EXCELÊNCIA EM GESTÃO E TECNOLOGIA, XII, 2015, Resende. Anais. Rio de Janeiro: AEDB, 2015.

FARIA, Suzi da Silva. Mapeamento do processo de compras públicas: uma ferramenta para gestão de materiais em saúde. 2017. 98 f. Dissertação (Mestrado Profissional em Enfermagem Assistencial) - Escola de Enfermagem Aurora de Afonso Costa, Niterói, 2017.

FIGUEIREDO, Moacyr Amaral Domingues; MACEDO-SOARES, Teresia Diana Lewe van Aduard de; FUKS, Saul; FIGUEIREDO, Lívia Cavalcanti. (2005). Definição de atributos desejáveis para auxiliar a auto-avaliação dos novos sistemas de medição de desempenho organizacional. Gestão \& Produção, 12(2), 305-315.

GIL, Antonio Carlos. Como elaborar projetos de Pesquisa. 5 ed, São Paulo, Atlas S.A., 2010 .

GOLDRATT, Elyahu M.; COX, Jeff. A meta. 17a. ed. São Paulo, Educator, 1994.

GOMES, Cristiane Wortmann. Método integrado de gestão de processos e conhecimento: aplicação em uma instituição federal de ensino superior. Dissertação (Mestrado Profissional em Engenharia de Produção) - Universidade Federal do Rio Grande do Sul, Porto Alegre, 2020.

GONÇALVES, J E L. As empresas são grandes coleções de processos. Revista de Administração de Empresas. São Paulo, v. 40, n. 1, p.6-19, Jan/Mar. 2000. 
GULLEDGE, Thomas; SOMMER, Rainer. (2002). Business process management: Public sector implications. Business Process Management Journal. 8. 364-376. 10.1108/14637150210435017.

HARRINGTON, James. Aperfeiçoando processos empresariais: estratégia revolucionária para o aperfeiçoamento da qualidade, da produtividade e da competitividade. São Paulo, Makron Books, 1993.

HOFFMANN, Diogo Silva; FILHO, Raimundo Nonato Lima. Reforma gerencial e indicadores de desempenho: uma revisão bibliográfica. Revista Contribuciones a las Ciencias Sociales, Málaga, v. 2017, p. 1-12, 2017.

HRONEC, Steven. M. Sinais vitais: usando medidas de desempenho da qualidade, tempo e custo para traçar a rota para o futuro de sua empresa. São Paulo, Makron Books, 1994.

$\mathrm{KOCH}$, Giovani Valar. Business process management (BPM) em instituições federais de ensino superior. Dissertação (Mestrado Profissional em Engenharia de Produção) Universidade Federal do Rio Grande do Sul, Porto Alegre, 2016.

KOTLER, Philip.; Keller, Kevin L., Administração de marketing; tradução Sônia Midori Yamamoto. - 14 ed. - São Paulo: Person Education do Brasil, 2012.

LACERDA, Daniel Pacheco; DRESCH, Aline; PROENÇA, Adriano; ANTUNES JÚNIOR, José Antonio Valle. Design Science Research: método de pesquisa para a engenharia de produção. Gestão \& Produção. São Carlos, v. 20, n. 4, p. 741-761, 2013.

LEMOS, J. E. S. de; RIBEIRO FILHO, C. A. de S.; RIBEIRO, R. E. M.; MOURA, K. B. de; CAVALCANTE, R. R. C.; FONSECA, A. R. N. Supporting decisions and guiding results with use of indicators in public management. Research, Society and Development, [S. 1.], v. 9, n. 8, p. e510985587, 2020. DOI: 10.33448/rsd-v9i8.5587. Disponível em: https://rsdjournal.org/index.php/rsd/article/view/5587. Acesso em: 5 jan. 2021.

MARQUES, F. Teoria Econômica e Compras Governamentais: Implicações para a concorrência. Dissertação (Mestrado em Economia) - IE/UFRJ. Rio de Janeiro, 2005.

MALLMANN, Elena Maria. Pesquisa-ação educacional: preocupação temática, análise e interpretação crítico-reflexiva. Cad. Pesquisa. São Paulo, v. 45, n. 155, p. 76-98, mar. 2015.

MAXIMIANO, A C. A. Teoria Geral da Administração: Da Revolução Urbana à Revolução Digital. 6 ed. São Paulo: Atlas, 2006.

MENDES, Janaína Mara Pacco. Proposta de indicadores de desempenho para os pregões eletrônicos do Campus Dourados do Instituto Federal de Mato Grosso do Sul. Dissertação (Mestrado Profissional em Administração Pública em Rede Nacional) - Faculdade de Administração, Ciências Contábeis e Economia, Universidade Federal da Grande Dourados, Dourados, 2019.

MENESES, Gustavo Vanderlei. Estratégia, indicadores e processos em uma empresa pública de transporte coletivo em massa de Porto Alegre. Dissertação (Mestrado 
Profissional em Engenharia de Produção) - Universidade Federal do Rio Grande do Sul, Porto Alegre, 2006.

MULLER, Cláudio J. Planejamento estratégico, indicadores e processos: uma integração necessária. São Paulo: Atlas, 2014.

NEELY, Andy; GREGORY, Mike; PLATTS, Ken. Performance measurement system design - a literature review and research agenda. International Journal of Operations \& Production Management. v. 25, n. 12, 2005, p. 1228 - 1263, 2005.

NISHIYAMA, Mario; LIMA, Marcus; ENSSLIN, Leonardo; CHAVES, Leonardo. (2017). Modelo Multicritério para Avaliação de Desempenho: um estudo de caso para gestão de compras no setor público. Revista de Ciências da Administração. 1. 09. 10.5007/21758077.2017v19n47p9.

OLIVEIRA, Aline de. Licitações nos EUA: exemplo para o Brasil? Disponível em: https://riooportunidadesdenegocios.com.br/produtos/noticias-de-impacto/licitacoes-nos-euaexemplo-para-o-brasil/5a8aced45e3cff1a007c86e3. 2018. Acessado em 22/01/2020.

OLIVEIRA, Andressa Luiza Bortolaso de. Fatores críticos de sucesso nas etapas de implantação do BPM em instituições federais de ensino superior. Dissertação (Mestrado Profissional em Engenharia de Produção) - Universidade Federal do Rio Grande do Sul, Porto Alegre, 2018.

OUYANG, Chun; ADAMS, Michael; WYNN, Moe; TER, Arthur. Workflow Management. In: Handbook on Business Process Management: Introduction, Methods, and Information Systems, v. 1, p. 387-418, Springer-Verlag Berlin Heidelberg, 2010.

PEREIRA, Valdinei Juliano. Compras públicas municipais: uma proposta de modelo de gestão para municípios de pequeno porte. Dissertação (Mestrado em Administração). Centro de Estudos Sociais Aplicados, Universidade Estadual de Londrina, Londrina, 2019.

PUGLIESE, Ana Carolina de Azeredo. Implantação de um plano de ação para a melhoria da performance do setor de licitações de uma instituição pública de ensino. Dissertação (Mestrado Profissional em Gestão e Estratégia) - Universidade Federal Rural do Rio de Janeiro, Mestrado Profissional em Gestão e Estratégia. 2019.

RAMOS, Daniel. Avaliação do sistema de gestão de licitações da TRENSURB. 2012. Monografia (Especialização em Gestão Municipal UAB Porto) - Universidade Federal do Rio Grande do Sul, Porto Alegre.

REIS, José Hildebrando Oliveira dos. Gestão de compras públicas: uma proposta para melhorar o processo de compras em um setor de saúde pública. Dissertação (Mestrado em Engenharia de Produção) - Universidade Federal do Amazonas, Manaus, 2017.

RIBEIRO, Tiago de Oliveira; DRUMOND, Geisa Meirelles; ESPIRITO SANTO, Marineuza Corrêa; MÉXAS, Mirian Picinin; COSTA, Helder Gomes da. Business process management no âmbito das instituições públicas: uma revisão sistemática. In: SIMPÓSIO DE EXCELÊNCIA EM GESTÃO E TECNOLOGIA, XII, 2015, Resende. Anais. Rio de Janeiro: AEDB, 2015. 
RUMMLER, Geary A.; BRACHE, Alan P. Melhores desempenhos das empresas. São Paulo: Makron, 1994.

SÁ, Raquel Brito Rojas; JULIATTO, Dante Luiz; FACCHINI, Édio; PINTUS, Rafael Pereira. Utilização da metodologia BPM para adequação de um sistema de gestão integrada e retenção de conhecimento em uma instituição pública de ensino superior. Revista Gestão Universitária na América Latina - GUAL. Santa Catarina. Edição especial, p.115-132, 2011.

SARAVIA-VERGARA, Enrique; SANCHÍS-PEDREGOSA, Carlos; ALBORT-MORANT, Gema. Organizational Culture, Process Management and Maturity of the Process: An Empirical Study of the Process Status in Peru. Global Business Review. First Published, mai, 2020.

SEVERINO, Antônio Joaquim. Metodologia do trabalho científico. 1 ed. São Paulo: Cortez, 2013.

SILVA, Edna Lúcia da.; MENEZES, Estera Muszkat. Metodologia da pesquisa e elaboração de dissertação. Florianópolis: UFSC/PPGEP/LED, 2000, 118P.

SILVA, Francisco Xavier da. Análise de processos de compras públicas: um estudo de caso no Instituto Federal de Mato Grosso do Sul - Campus Coxim. Dissertação (Mestrado Profissional em Engenharia de Produção) - Universidade Federal do Rio Grande do Sul, Porto Alegre, 2018.

SILVA, Jorge Gonçalves. Gestão por processos em organizações públicas: uma análise sobre obstrutores e facilitadores do mapeamento de processo em organizações públicas Dissertação (Mestrado Profissional em Administração Pública) - FGV - Fundação Getúlio Vargas, Rio de Janeiro, 2014.

SILVA, Alana Teles. Melhoria de processos integrada ao ciclo PDCA: uma análise nas aquisições de bens do IFS - Campus Aracaju. 148f. Dissertação (Mestrado Profissional em Gestão Pública) - Centro de Ciências Sociais Aplicadas, Universidade Federal do Rio Grande do Norte, Natal, 2019.

SLACK, Nigel; BRANDON-JONES, Alistair; JOHNSTON, Robert. Administração da produção; tradução Daniel Vieira. - 8 ed. São Paulo: Atlas, 2018.

SOUZA, Rommel; MISAGHI, Mehran; GRAZIANI, Álvaro. Elaboração de indicadores chave de desempenho: setor de obras públicas das autarquias federais. Revista Gestão Pública Práticas e Desafios. v. 12, n. 1. 2020.

STEMBERGER, Mojca; BUH, Brina; MILANOVIC GLAVAN, Ljubica; MENDLING, Jan. (2018). Propositions on the interaction of organizational culture with other factors in the context of BPM adoption. Business Process Management Journal. v. 24, n. 2, p. 425-445, fev. 2018.

TCU, 2000. Brasil. Tribunal de Contas da União. Técnicas de Auditoria: Indicadores de Desempenho e Mapa de Produtos. Brasília: TCU, Coordenadoria de Fiscalização e Controle, 2000 . 
TRILHA, Carla Cristina da Silveira; ALVES, Guilherme Krause; NUNES, Rogério da Silva. Avaliação dos processos de compras com dispensa de licitação: estudo em uma universidade federal. Navus - Revista de Gestão e Tecnologia, [S.1.], v. 8, n. 2, p. 73-86, apr. 2018.

TRINDADE, Leandro Lopes. Análise da Eficiência dos Processos de Compras Públicas: Um Estudo de Caso na Universidade Federal de Itajubá. 2016. Dissertação (Mestrado) Instituto de Engenharia de Produção e Gestão, Universidade Federal de Itajubá, MG.

UBAID, Alaa; DWEIRI, Fikri. (2020). Business process management (BPM): terminologies and methodologies unified. International Journal of System Assurance Engineering and Management. 10.1007/s13198-020-00959-y.

UFRGS, 2020. Universidade Federal do Rio Grande do Sul. Relatório de gestão 2019. Porto Alegre, 2020. Disponível em: https://www.ufrgs.br/governanca/informacoesinstitucionais/relatorio-de-gestao/ . Acessado em 19/02/2021.

WESKE, Mathias. Business Process Management Concepts, Languages, Architectures. Springer-Verlag Berlin Heidelberg, Second Edition, 2012. 
ANEXOS 
ANEXO 1 - Organograma da UFRGS

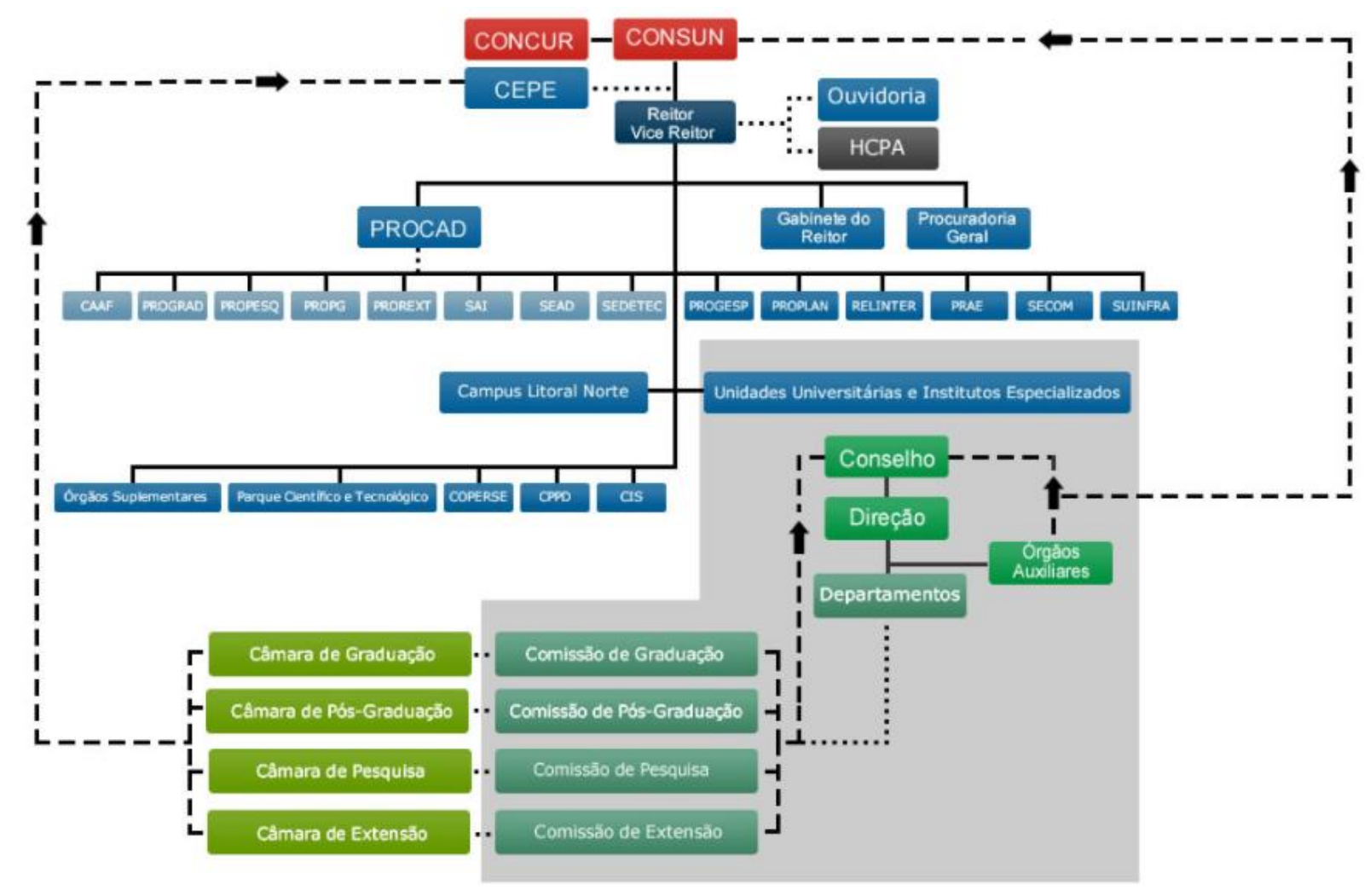


ANEXO 2 - Organograma da PROPLAN

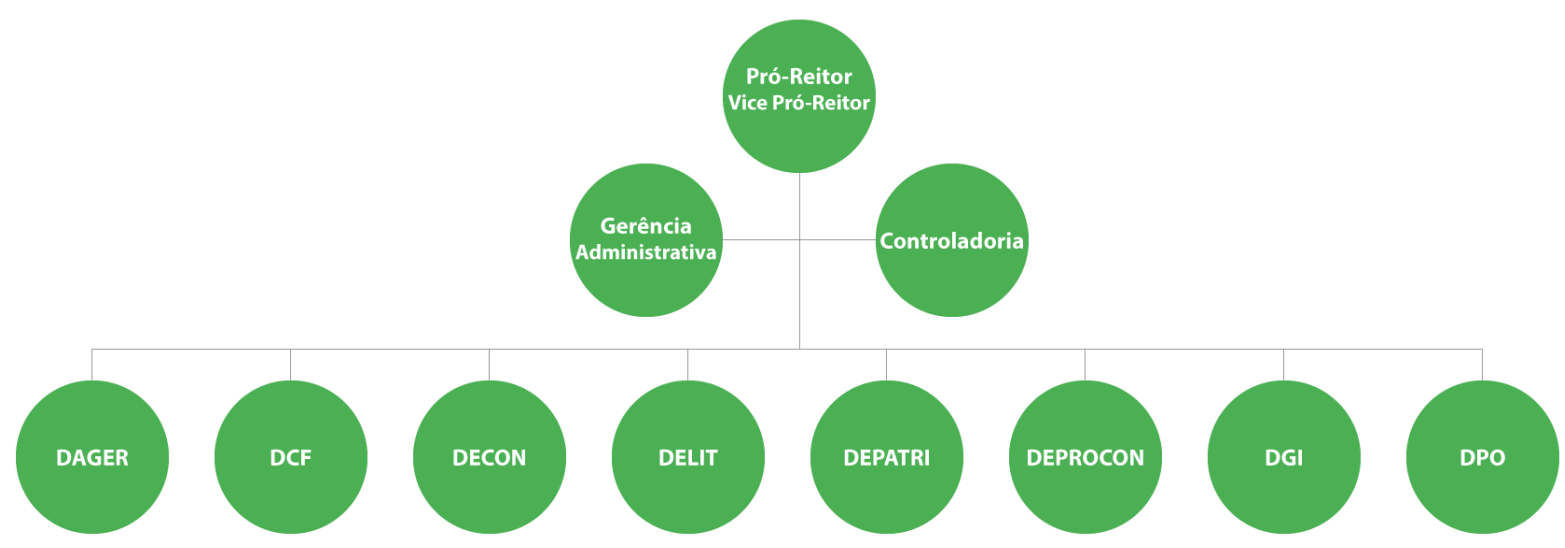




\section{ANEXO 3 - Atribuições do DELIT}

Departamento de Aquisição de Bens e Serviços

O Departamento de Aquisição de Bens e Serviços (DELIT) atua no planejamento e controle das aquisições e licitações da UFRGS.

Diretor: José João Maria de Azevedo

Saiba mais

DIVLIC

E-mail: jose.azevedo@ufrgs.br

Saiba mais

Telefone: (51) 3308-3925

DPCA

Localização: Av. Paulo Gama, 110 -

Reitoria $-5^{\circ}$ andar - Campus Centro Porto Alegre/RS

Saiba mais

Saiba mais 


\section{ANEXO 4 - Exemplo dos documentos de um processo licitatório no SEI}

\begin{tabular}{|c|c|}
\hline \multicolumn{2}{|c|}{$\begin{array}{l}\text { UNVERSIDADEFEDERAL DO RIO GRANDE DO SI } \\
\text { SEl. }\end{array}$} \\
\hline \multicolumn{2}{|c|}{ Controle de Processos } \\
\hline \multicolumn{2}{|c|}{ Iniciar Processo } \\
\hline \multicolumn{2}{|c|}{ Retorno Programado } \\
\hline \multicolumn{2}{|c|}{ Pesquisa } \\
\hline \multicolumn{2}{|c|}{ Base de Conhecimento } \\
\hline \multicolumn{2}{|c|}{ Textos Padrão } \\
\hline \multicolumn{2}{|c|}{ Modelos Favoritos } \\
\hline \multicolumn{2}{|c|}{ Blocos de Assinatura } \\
\hline \multicolumn{2}{|c|}{ Blocos de Reunião } \\
\hline \multicolumn{2}{|c|}{ Blocos Internos } \\
\hline \multicolumn{2}{|c|}{ Contatos } \\
\hline \multicolumn{2}{|c|}{ Processos Sobrestados } \\
\hline \multicolumn{2}{|c|}{ Acompanhamento Especial } \\
\hline \multicolumn{2}{|c|}{ Marcadores } \\
\hline \multicolumn{2}{|c|}{ Pontos de Controle } \\
\hline Estatisticas & - \\
\hline Grupos & - \\
\hline \multicolumn{2}{|c|}{$\begin{array}{l}\text { Acesse as lojas App Store ou Google } \\
\text { Play e instale o aplicativo do SEl! no seu } \\
\text { celular. }\end{array}$} \\
\hline \multicolumn{2}{|c|}{$\begin{array}{l}\text { Abra o aplicativo do SEl! e faça a leitura } \\
\text { do código abaixo para sincronizá-lo com } \\
\text { sua conta. }\end{array}$} \\
\hline & \\
\hline
\end{tabular}

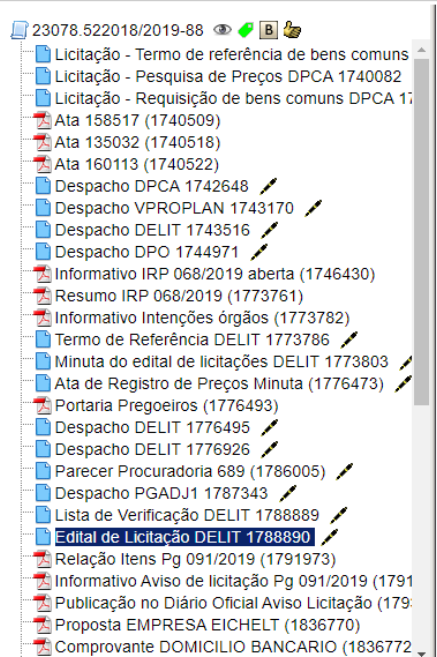

Para saber* Menu Pesquisa

DPCA

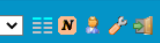

Licitacão- Termo de referência de be

Licitação - Termo de referência de bens comuns

Lesquisa de Preços DPCA 1740082

Ata 158517 (1740509)

Ata $160113(1740522)$

Despacho DPCA 1742648

Despacho VPROPLAN 1743170

Despacho DELIT 1743516

Informativo IRP 068/2019 aberta (1746430)

Resumo IRP 068/2019 (1773761)

Termo tu Renç

Minuta do edital de licitações DELIT 1773803

(1776493)

Despacho DELIT 1776495

Despacho PGADJ1 1787343

(17)

Relação Itens Pg 091/2019 (1791973)

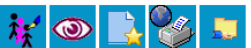

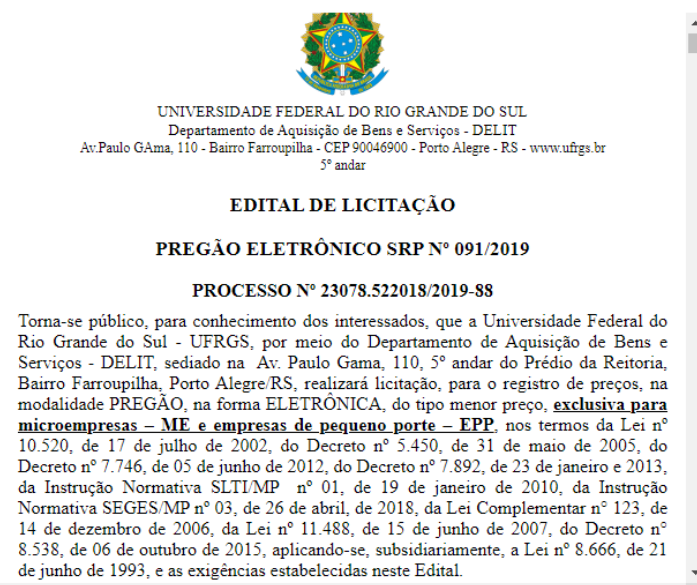

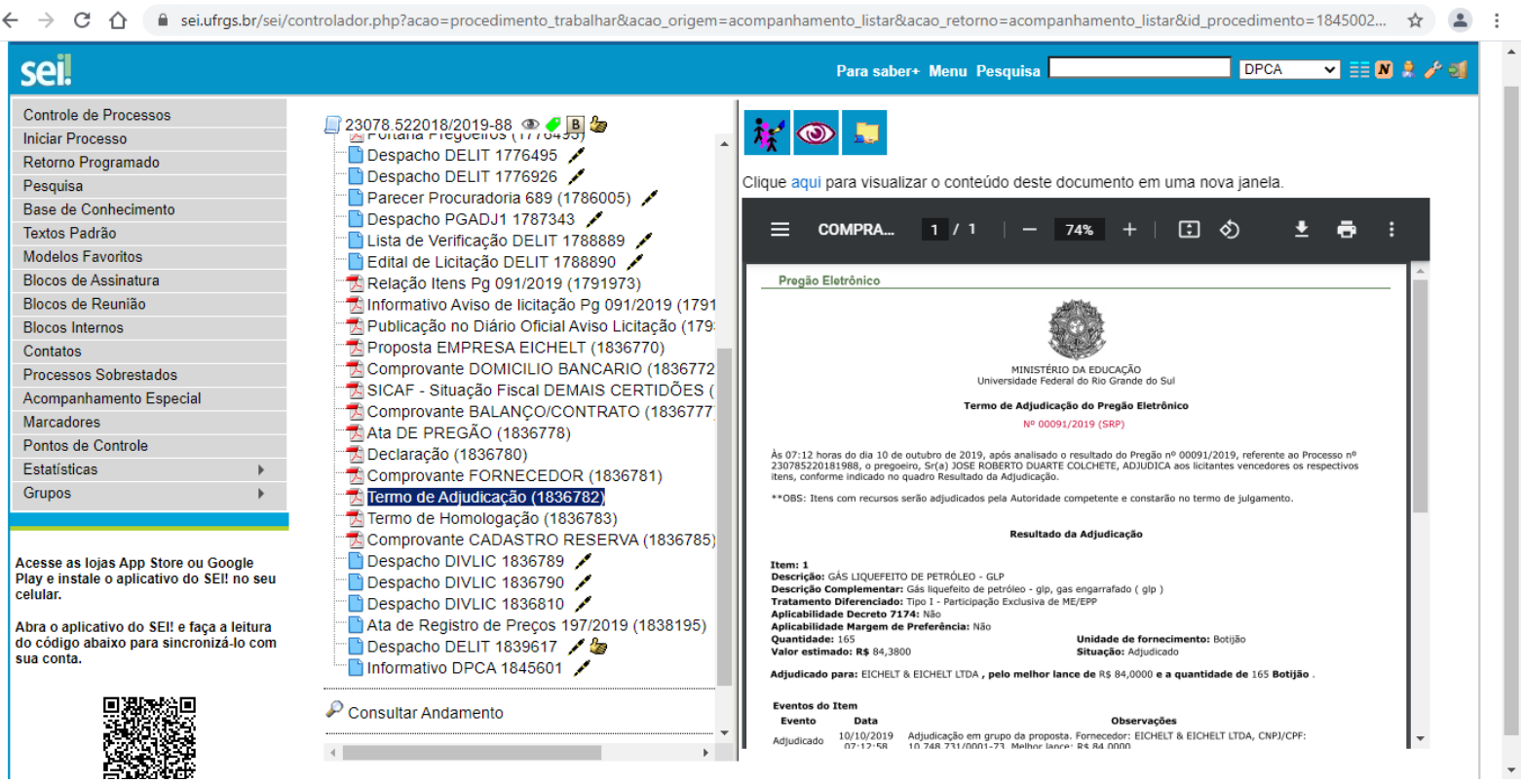




\section{ANEXO 5 - Exemplo do Livro DELIT}

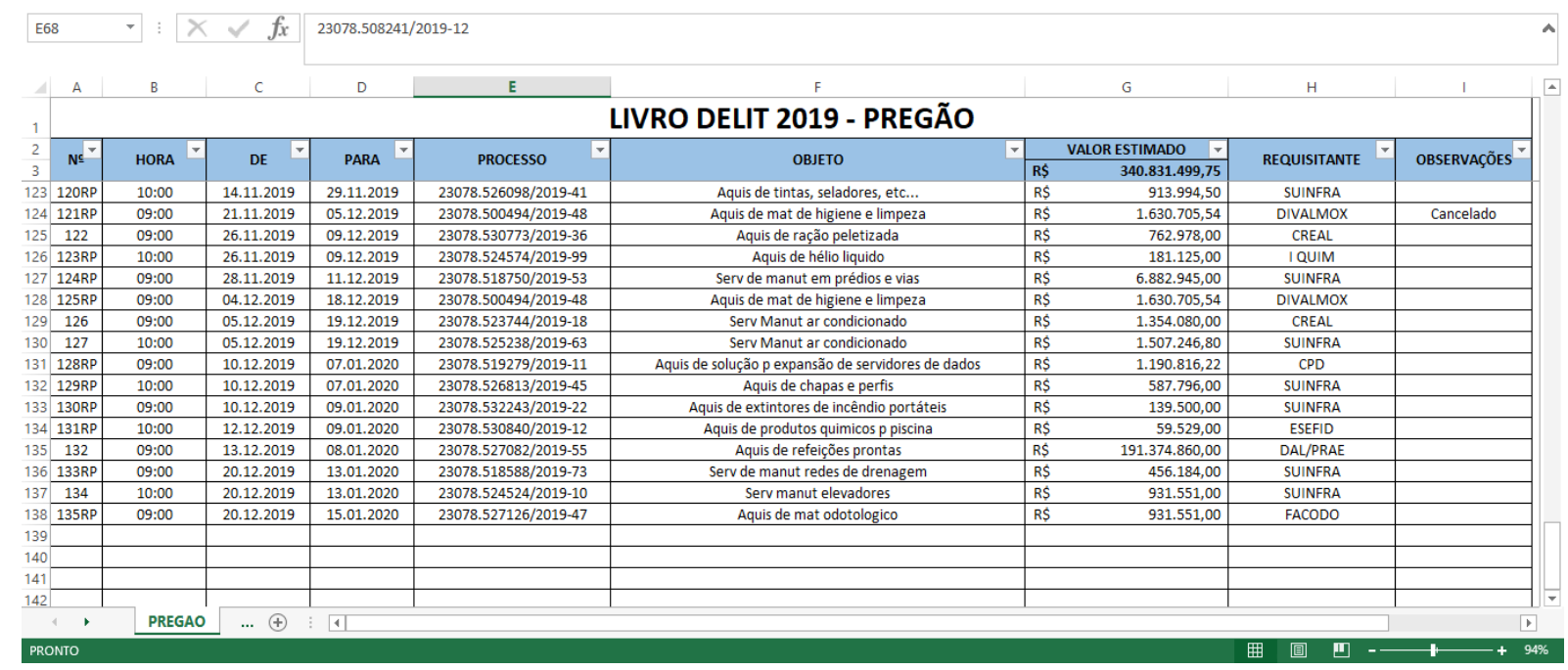


ANEXO 6 - Exemplo do resultado de um processo licitatório no Comprasnet

$\leftarrow \rightarrow C$ A Inseguro $\mid$ comprasnet.gov.br/livre/Pregao/ata2.asp?co_no_uasg=153114\&\&numprp=912019\&f_IstSrp=\&f_Uf=\&f_numPrp=912019\&f_codUasg=153114\&f_tpPregao=E\&f_Is... is

D CONSULTA ATA DO PREGÄO

UASG 153114-UFRS-UNIVERSIDADE FEDERAL DO RS/RS

Pregão $n^{\circ}: \quad N^{0} 00091 / 2019$ (SRP)

Ata do Pregão - 10/10/2019 07:11

Resultado por Fornecedor Declaraçes Ata do Cadastro de Reserva

Voltar Anexos dos Itens Termo de Adjudicaçäo Termo de Homologaçäo

Impugnacōes

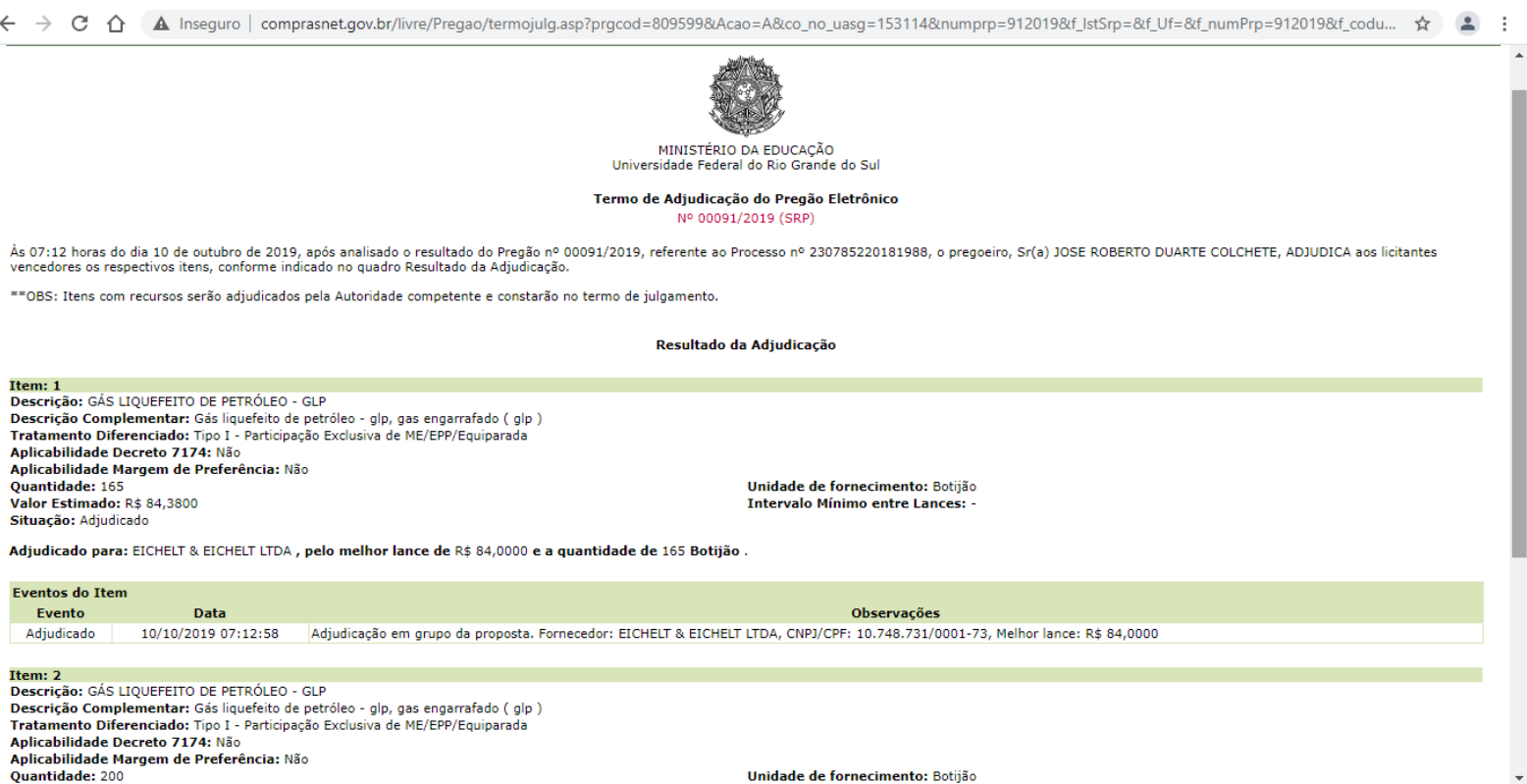

